\title{
FLOODS IN PUERTO RICO, MAGNITUDE AND FREQUENCY
}

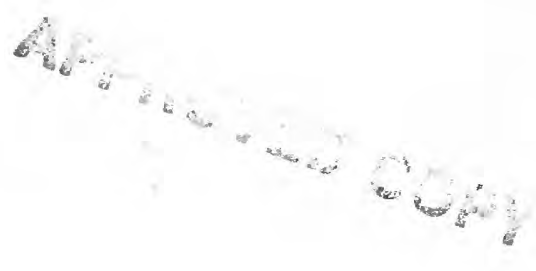

\section{U.S. GEOLOGICAL SURVEY}

Water Resources Investigations 78-141

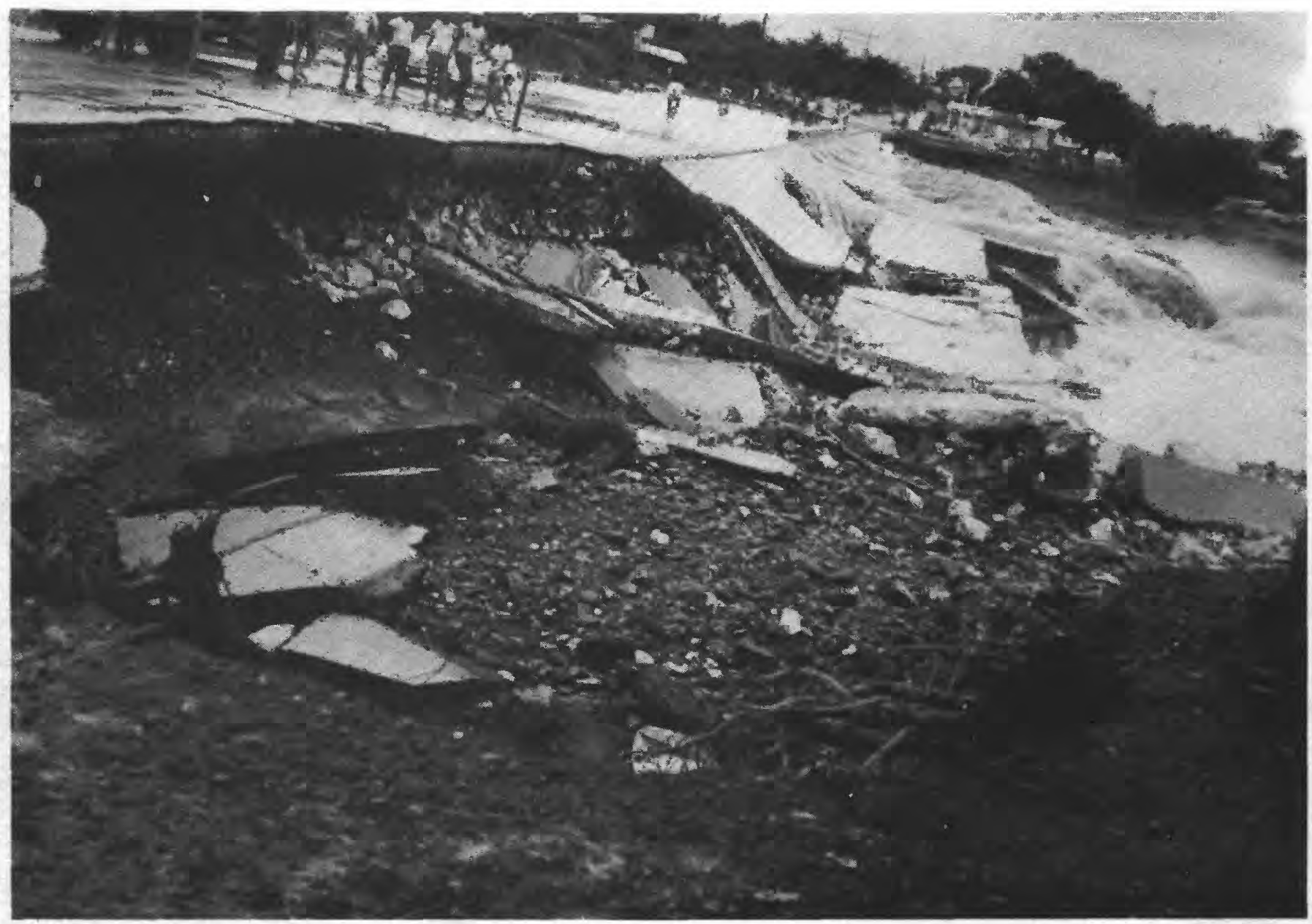

\section{Prepared in cooperation with the COMMONWEALTH OF PUERTO RICO}




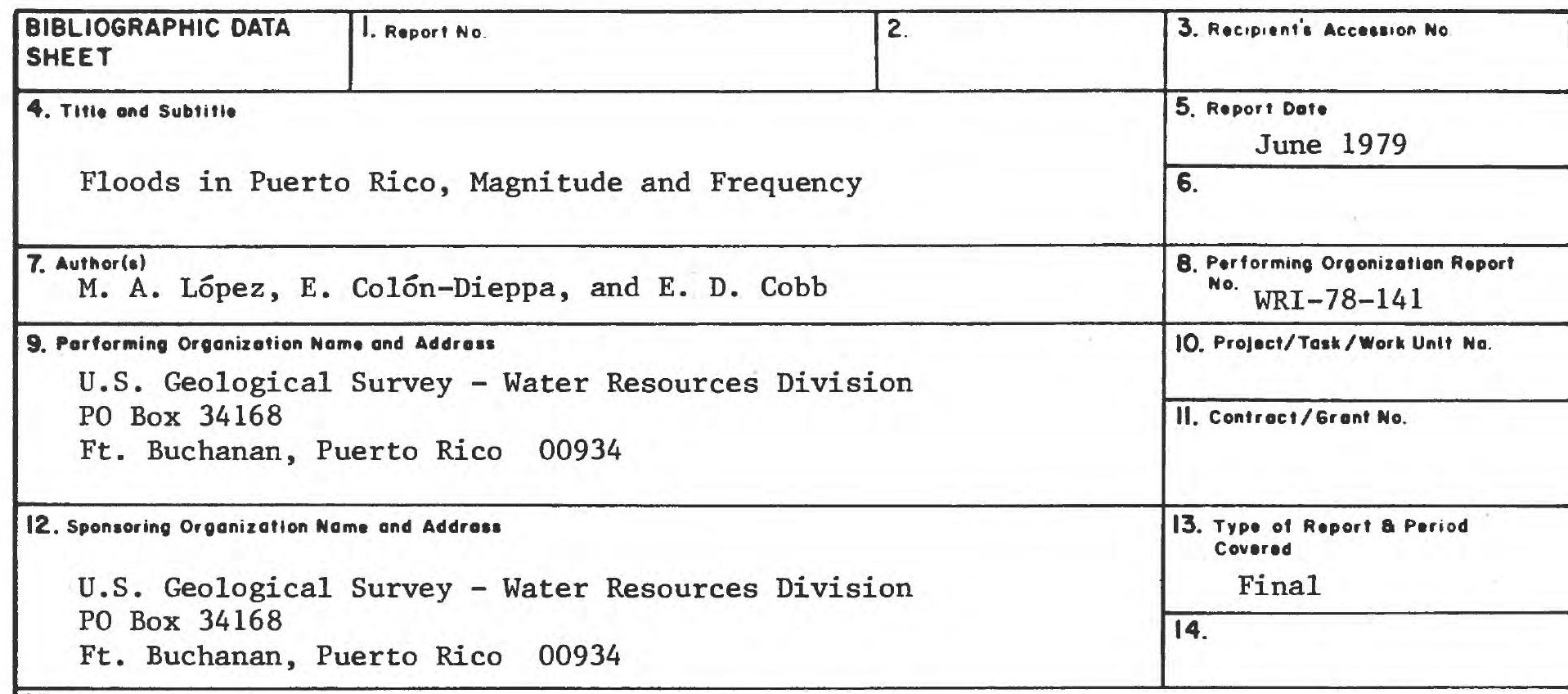

15. Suplementery Notes

Prepared in cooperation with the Commonwealth of Puerto Rico

16. Abstrocts

Annual peak-discharge records at 50 sites with 5 or more years of record were used to determine individual site log-Pearson Type III frequency curves. The logPearson Type III frequency curve values for 2-, 10-, 25-, 50-, and 100-year recurrence interval at 37 sites with 10 or more years of record were regressed against basin characteristics. Drainage area and mean annual rainfall proved to be the only independent variables significant at the 95 percent confidence level in these regression equations.

17. Key Words and Document Analysis

17a. Descriptors

*Frequency analysis, *statistical methods, *floods, correlation analysis, regression analysis, probability, recurrence interva1, log-Pearson. Type III frequency distribution, peak discharge, streamflow, precipitation, drainage area.

17b. Identifiers/Open-Ended Terms

Puerto Rico

17c. CosatI Flold/Group

18. Availabilliy Statement

No restriction on distribution

19. Securlty Class (This Repori)

UNCLASSIFIED

20. Securlty Cless (This Poge)

UNCLASSIFIED
2I. No. of Poges 70

22. Price

US COW W-DC e263-p74 
FLOODS IN PUERTO RICO,

MAGNITUDE AND FREQUENCY

By M. A. López, Eloy Colón-Dieppa, and E. D. Cobb

U.S. GEOLOGICAL SURVEY

Water Resources Investigations 78-141

Prepared in cooperation with the

Commonwealth of Puerto Rico

June 1979

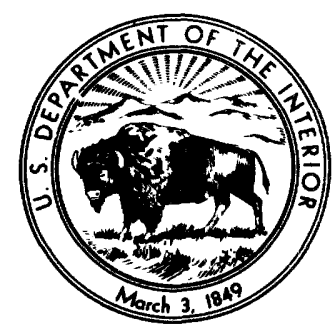


UNITED STATES DEPARTMENT OF THE INTERIOR

CECIL D. ANDRUS, Secretary

GEOLOGICAL SURVEY

H. William Menard, Director

For additional information write to:

U.S. Geological Survey, WRD .

Building 652; P.0. Box 34168

Ft. Buchanan, P.R. 00934 


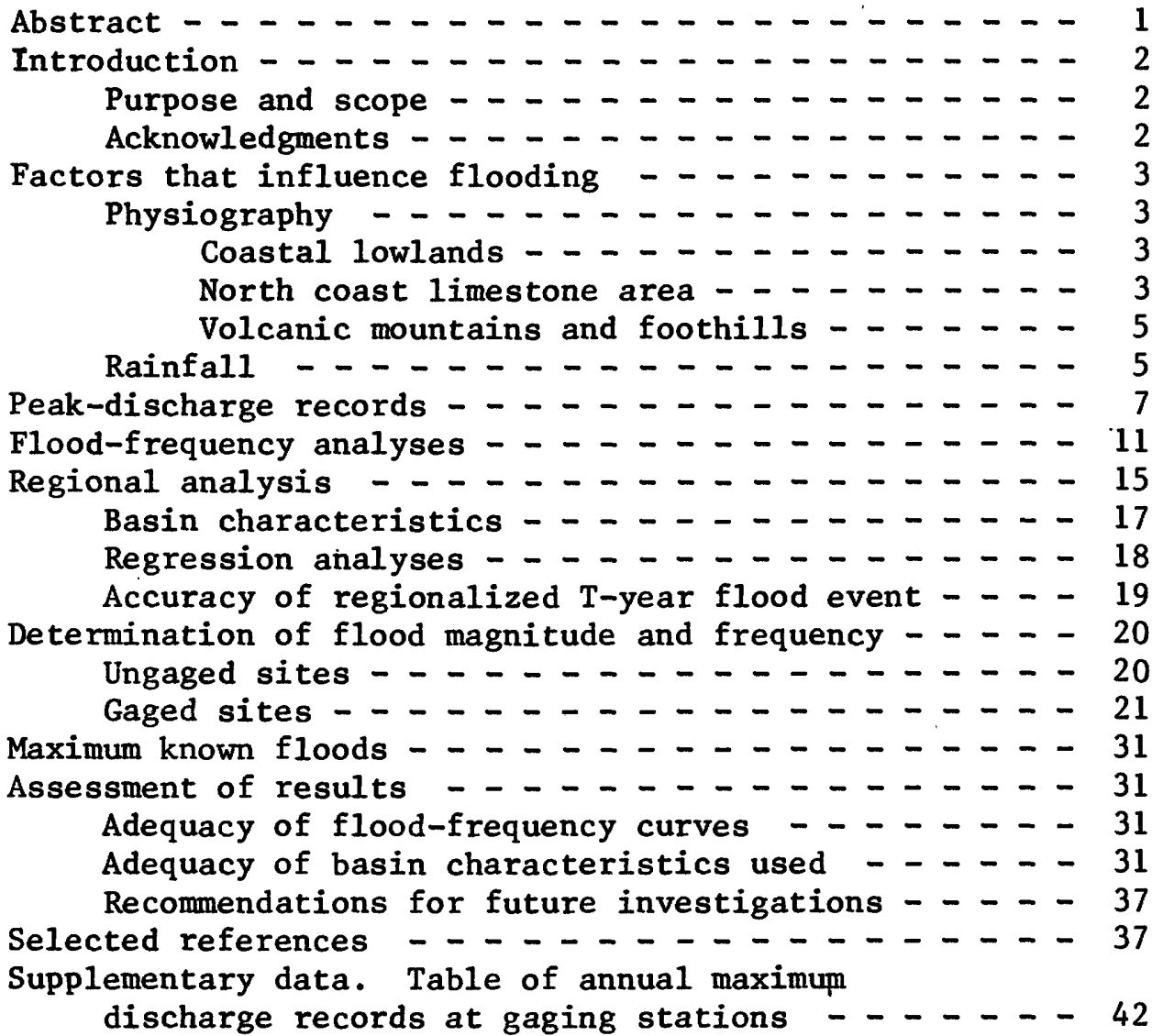

\section{ILLUSTRATIONS}

Figure

1 Map showing hydrologic subdivisions, major river systems and locations of streamflor stations in Puerto Rico _ - $\ldots$ - $\ldots \ldots$ - $\ldots$

2 Map showing mean annual rainfall in Puerto Rico - - - 6

3 Map showing area experiencing outstanding flooding in $1960 \ldots \ldots-\ldots$

4 Map showing area experiencing outstanding flooding in $1970 \ldots \ldots$. $-\ldots \ldots$ 


\section{ILLUSTRATIONS--Continued}

Page

Figure

5 Map showing area experiencing outstanding flooding

in $1975 \ldots \ldots+\ldots$

6 Map showing areas in Puerto Rico for which flood atlases have been prepared _ - $-\ldots+\ldots 12$

7 List of annual-peak discharge records in Puerto Rico - - 13

8 Diagram for determining the 2-year flood-peak discharge at ungaged sites in Puerto Rico _ _ _ _ _ _ - 22

9 Diagram for determining the 10-year flood-peak discharge at ungaged sites in Puerto Rico - _ _ - 23

10 Diagram for determining the 25-year flood-peak discharge at ungaged sites in Puerto Rico _ - _ $\ldots$

11 Diagram for determining the 50-year flood-peak discharge at ungaged sites in Puerto Rico - _ - $\ldots$

12 Diagram for determining the 100-year flood-peak discharge at ungaged sites in Puerto Rico - _ - . - . -

13 Graph of maximum known floods in Puerto Rico prior to January 1, $1976 \ldots \ldots-\ldots$

TABLES

Table

1 Hydrologic investigations atlases (Puerto Rico) - - - - 14

2 Log-Pearson Type III flood-frequency discharge at selected sites in Puerto Rico - _ - _ - - - -

3 Maximum known floods in Puerto Rico prior to January 1, $1976 \ldots+\ldots$ 


\section{FLOODS IN PUERTO RICO,}

MAGNITUDE AND FREQUENCY

by M. A. López, Eloy Colón-Dieppa and E. D. Cobb

\section{ABSTRACT}

Annual-peak discharge records at 50 sites with 5 or more years of record were used to determine individual site log-Pearson Type III frequency curves. The log-Pearson Type III frequency curve values for $2-, 10-, 25-, 50-$, and 100-year recurrence intervals at 37 of these sites with 10 or more years of record were regressed against basin characteristics. Drainage area and mean annual rainfall proved to be the only independent variables significant at the 95 percent confidence level. The regression equations are:

$$
\begin{array}{lll}
\mathrm{Q}_{2}=0.033 \mathrm{~A} .776 \text { (Ann P) } & 2.11 & \mathrm{SE}_{\mathrm{R}}=+51,-34 \text { percent } \\
\mathrm{Q}_{10}=3.72 \mathrm{~A} .822 \text { (Ann P) } 1.29 & \mathrm{SE}_{\mathrm{R}}=+45,-31 \text { percent } \\
\mathrm{Q}_{25}=25.7 \mathrm{~A} .826 \text { (Ann P) } .953 & \mathrm{SE}_{\mathrm{R}}=+50,-33 \text { percent } \\
\mathrm{Q}_{50}=89.9 \mathrm{~A} .830 \text { (Ann P) } .734 & \mathrm{SE}_{\mathrm{R}}=+55,-36 \text { percent } \\
\mathrm{Q}_{100}=286 \mathrm{~A} .832 \text { (Ann P) } .531 & \mathrm{SE}_{\mathrm{R}}=+61,-38 \text { percent }
\end{array}
$$

where $Q$ is the $T$-year recurrence interval peak discharge,

$A$ is the drainage area in square miles,

(Ann $P$ ) is the weighted mean annual precipitation in inches, and $\mathrm{SE}$ is the standard error of estimate of the regression. 


\section{INTRODUCTION}

Knowledge of flood experience and flood potential is important for the planning of use of flood plains and the development of all property adjacent to streams. It is an important criterion in the design of structures especially highway culverts and bridges. Improper design can lead to loss of life and property on one hand and to financial waste on the other. Proper design is both a human and economic necessity.

The concept of frequency of extreme values of a natural event is an elusive factor. Statistical evaluation requires the assumption that available data are representative of a much larger data group. The equations presented estimate floods of large recurrence intervals based on relatively short, finite-time samples at gaged sites. Whenever a significant amount of new data or a more effective method or technique of analysis becomes available, a new study may be warranted to improve definition of future floods.

A previous study of magnitude and frequency of floods in Puerto Rico was made in a U.S. Geological Survey open-file report entitled "A Proposed Streamflow-Data Program for Puerto Rico" prepared in cooperation with the Commonwealth of Puerto Rico by M. A. López and F. K. Fields (1970). This report used records through December 1969 and presented equations for the 5-, 10-, 25-, and 50-year recurrence-interval floods. Since the publication or release of this report, 6 more years of record and new techniques for frequency analysis are available.

\section{Purpose and Scope}

The purpose of this report is to document flood data for gaged sites, historical flood data, and to provide methods for estimating flood potential at ungaged sites on unregulated streams in Puerto Rico.

All flood data in Puerto Rico through December 1975 were analyzed. Shortterm records were extended to include historic flood records. Frequency curves were computed by methods that tend to reduce time-sampling errors. A stepwise regression technique was used to relate flood frequency at the gaged sites to areal parameters.

\section{Acknowledgments}

This report was prepared as part of the cooperative program for waterresources investigations with the following agencies of the Commonwealth of Puerto Rico: Environmental Quality Board, Department of Natural Resources, Department of Transportation and Public Works, Water Resources Authority, and Aqueduct and Sewer Authority. Data contributed by the Commonwealth agencies, Federal agencies, and individuals are specifically acknowledged in the text or tables containing these data. A listing of all reports used appears in the Selected References. 


\section{FACTORS THAT INFLUENCE FLOODING}

Flood magnitudes are affected by physiography, rainfall, and manmade regulation. In a homogeneous region, physiographic factors such as ground slopes, infiltration capacity of soils, stream patterns, and capacities of stream channels are considered to be relatively similar in their influence on floods. Climatic factors such as type, magnitude, and time distribution of flood-producing storms are subject to the variations of chance and are primarily responsible for the variation in flood magnitudes in an otherwise homogeneous region. Manmade storage may significantly affect the magnitude of flood-peak discharge, and channel improvements can affect peak stage as well as peak discharge. The effect of reservoirs on flood-frequency relationship is discussed in a later section.

\section{Physiography}

Puerto Rico is one of a long chain of mountainous islands that stretches from just south of Florida, North America, to Venezuela, South America. The principal topographic feature of the island is the Cordillera Central, which is the line of highest mountains running east-west and dividing the island into a northern two-thirds and a southern one-third. The Cordillera forms the principal drainage divide of the larger streams. River valleys are deeply incised into the mountain slopes, and the general characteristic is ruggedness.

Character and history of rocks and topographic characteristics of Puerto Rico are diversified and highly complex. Generalized physiographic regions for the island have been described by Picó (1950), and a hydrogeologic map by Briggs and Akers (1965) has defined hydrologic properties of the geologic formations. Each physiographic region or area contains a variety of landforms but these have been combined with the hydrogeologic divisions into three principal subdivisions: coastal lowlands, north coast 1imestone, and volcanic mountains and foothills. These subdivisions and major river systems are shown. in figure 1 .

\section{Coastal Lowlands}

Coastal lowlands are defined as the relatively flat areas at elevations less than $164 \mathrm{ft}(50 \mathrm{~m})$ above mean sea level. The flood runoff of the lowland areas is limited by the flat overland slopes and meandering channels. Floodpeak runoff originating in the higher elevations easily overflows the entrenched channel onto the flood plains. Consequently, flood-peak discharge is attenuated by channel and overbank storage as the flood moves through the valley to the ocean.

\section{North Coast Limestone Area}

A complete hydrologic description of the north coast limestone area is given by Giusti and Bennett (1976). The landforms developed on the north coast 


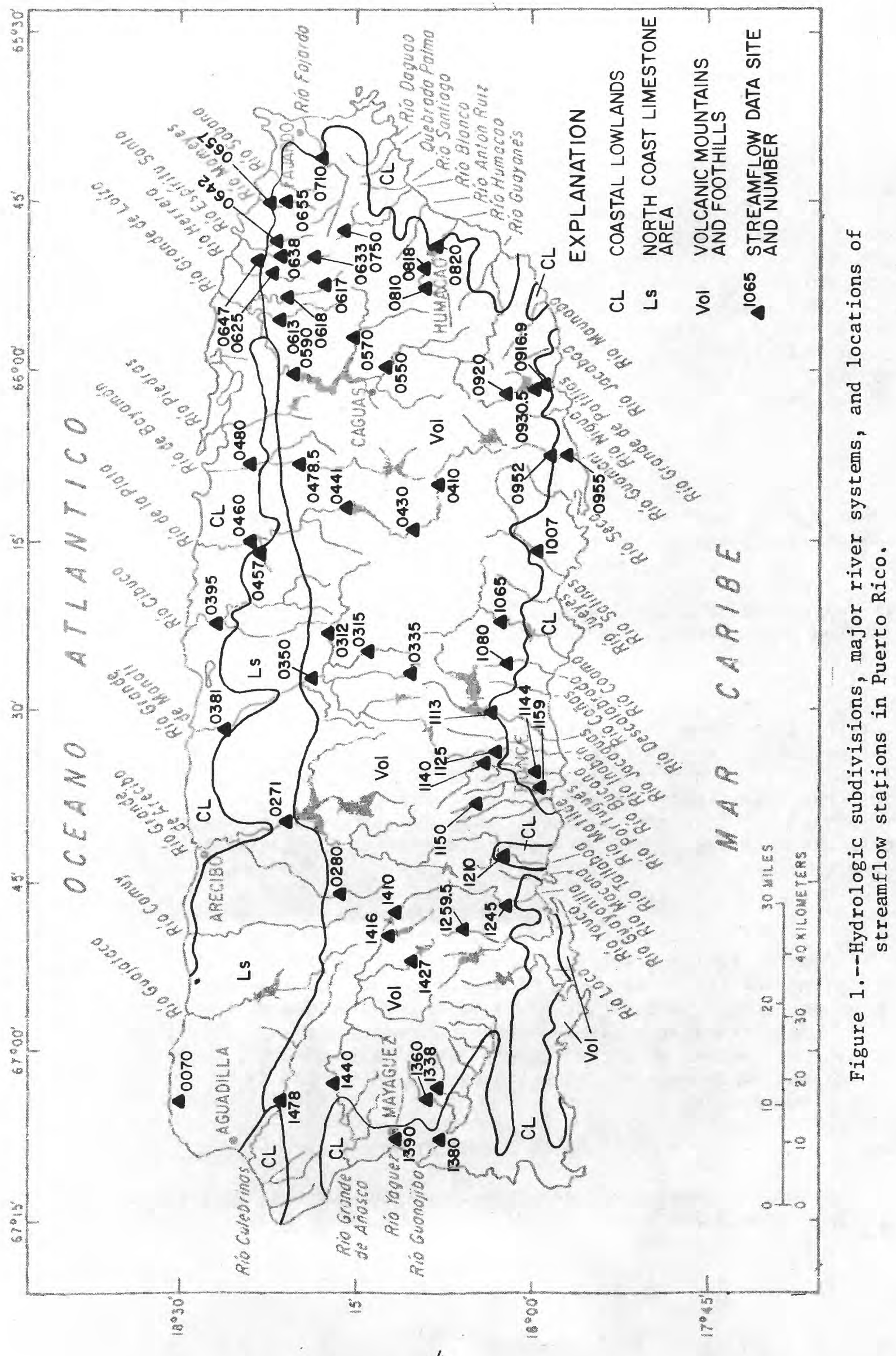


limestone area constitute one of the finest examples of tropical karst in the world: the main features are the mogotes (haystack hills), sinkholes, and the absence of major surface drainage. The north-flowing streams have cut through the limestone to form narrow gorges, and in the case of Ríos Camuy and Tanama flow underground at several points. Flooding is confined to the narrow valleys which gradually widen as they reach the coastal lowlands.

The are areas that are not connected directly by surface drainage to the streams, and although runoff from these areas may appear in the river as streamflow shortly after a flood, it arrives too late to contribute to the peak. Only the area that has a defined surface-drainage connection with the stream is used in computing peak discharge.

\section{Volcanic Mountains and Foothills}

The interior mountain backbone of Puerto Rico, the Cordillera Central, is a topographically high, rugged, mountainous row of peaks ranging in elevation from 2,000 to $4,390 \mathrm{ft}(610$ to $1,340 \mathrm{~m})$. Sierra de Luquillo, a group of high peaks in the northeast corner of the island, reach elevations of 3,450 to $3,520 \mathrm{ft}(1,050$ to $1,070 \mathrm{~m})$. South-flowing streams fall steeply from the divide to the coast within $8 \mathrm{mi}(13 \mathrm{~km})$ near the east end of the Cordillera Central and within 12 to $15 \mathrm{mi}$ (19 to $24 \mathrm{~m}$ ) throughout the rest of the south coast. Fast-flowing streams have cut steep-sided valleys through the uplands and deposited boulders, gravel, sand, and silt along the south coast lowlands.

Larger streams flow northward and westward from the Cordillera Central. These streams, too, have cut steep-sided valleys through the upper reaches, but well developed flood plains are found in some interior valleys. Streams draining the Sierra de Luquillo are generally short and steep without any extensively developed valleys. The steep ground and channel slopes cause rapid runoff which causes "flash flood" type peaks.

\section{$\underline{\text { Rainfa11 }}$}

Puerto Rico has a tropical marine climate, and is in a belt of prevailing northeasterly trade winds. As a result of orographic effects, a large amount of rainfall occurs on the windward (north and east) slopes of the mountains, and the mean-annual rainfall pattern is greatly affected by the topography. Areas of highest rainfall coincide with the higher elevations of Sierra de Luquillo and the Cordillera Central as shown in figure 2.

Flood-producing storms are more prevalent during the "hurricane season" of July through October. Rainfall during these months is normally caused by slow-moving low-pressure systems that cover large areas. These "tropical depressions" can develop enough circulation to be classified as hurricanes and cause serious wind damage as well as heavy rainfall. Severe flooding has been associated with hurricanes and tropical storms that have passed close to the island, such as Donna in 1960 (Barnes, 1961) and Eloise in 1975. 


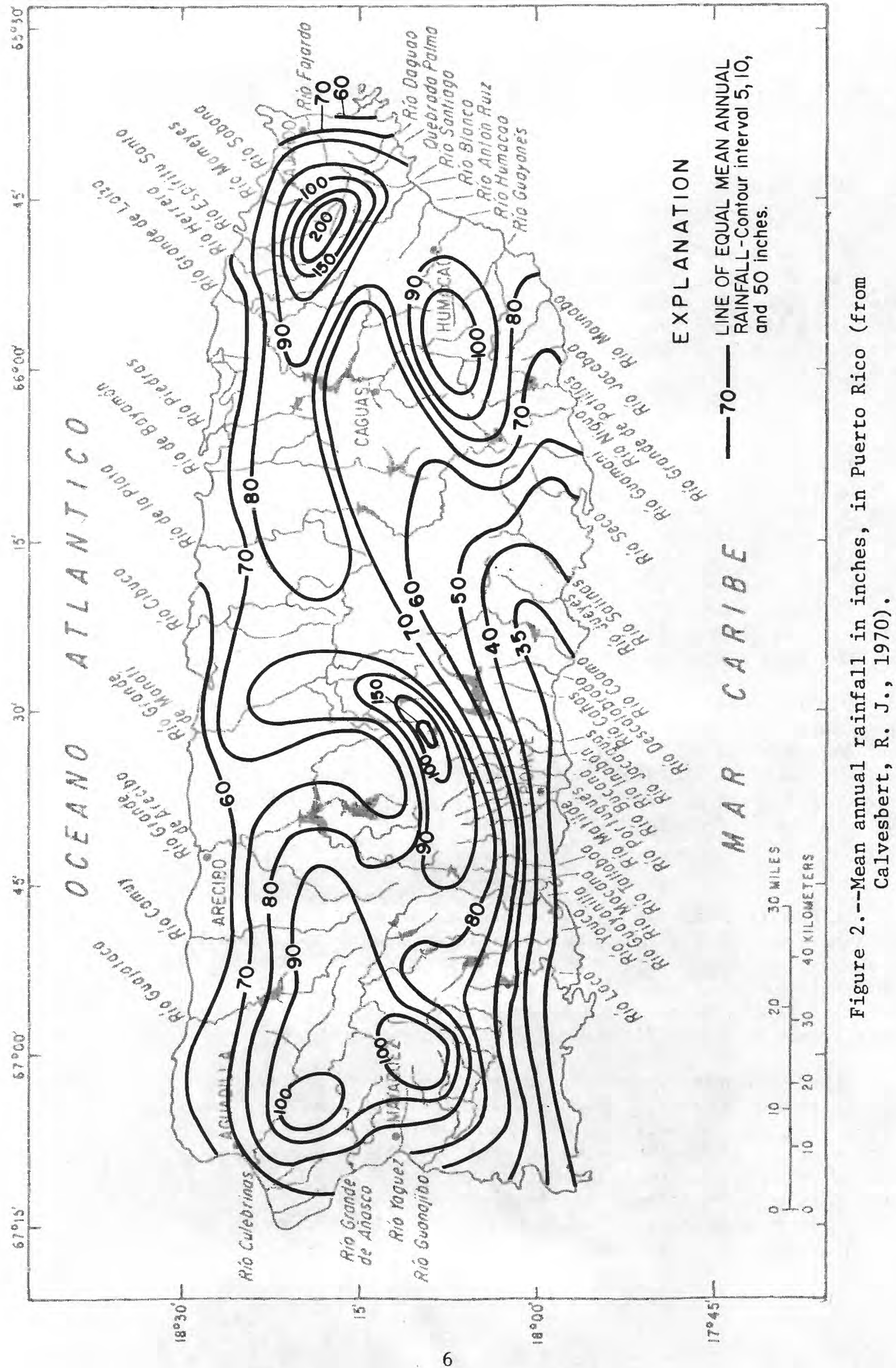


Other major rainfall-producing situations occur during the winter from about November to March. During this period the trailing edge of a cold front occasionally penetrates far enough south to affect Puerto Rico. A strong, active but slowly moving front is capable of bringing heavy and continuing rainfall, lasting for several days.

Convective-type rainfall of short duration but high intensity generally occurs during April, May, and June. These localized storms can cause serious flooding in small areas, but usually are too limited areally to cause major flooding on the large rivers.

The eastern two-thirds of the island has experienced significant flooding several times since 1959. The most severe floods occurred on September 6 , 1960, during October 7-9, 1970, and in September 1975. The areas affected in 1960 and 1970 are shown in figures 3 and 4. The southwestern part of the island suffered severe flooding only once since 1959. The September 16, 1975, flooding affected the area shown in figure 5.

An early investigation of the occurrence of high-intensity rainfall and the resultant flood discharges was made by Quiñones (1952). A later study was published by the U.S. Weather Bureau in 1961, Technical Paper No. 42, "Generalized Estimates of Probable Maximum Precipitation and Rainfal1-Frequency for Puerto Rico and Virgin Islands." These estimates were based on data from a single recording rainfall station in San Juan and a mathematical hurricane model. Lack of recording rainfall data prevented verification of the model. Since June 1971, the National Weather Service has been collecting continuous rainfall data at 13 sites throughout the island. Ten additional sites were added in June 1973. As these data are processed and analyzed, a better estimate of the rainfall intensity and frequency is expected.

A detailed description of the climate of Puerto Rico is available in the U.S. Department of Commerce publication "Climate of Puerto Rico and U.S. Virgin Islands, Climatography of the United States No. 60-52" (Calvesbert, 1970 ).

\section{PEAK-DISCHARGE RECORDS}

Flood-peak discharge data for this report were largely derived from streamflow records collected by the U.S. Geological Survey, Puerto Rico Water Resources Authority, and the Puerto Rico Aqueduct and Sewer Authority. The supplementary data table contains annual peak-discharge data used in floodfrequency regionalization.

The stations in the supplementary data table (p. 46-70) are 1isted in consecutive downstream order with numbers assigned by the Geological Survey. The stations are identified by these numbers in figure 1 . The drainage area listed for each station is that which has a defined surface drainage system linking it to the stream channel. Some sites, especially along the north coast limestone area, have some depressions or closed basins in which storm 


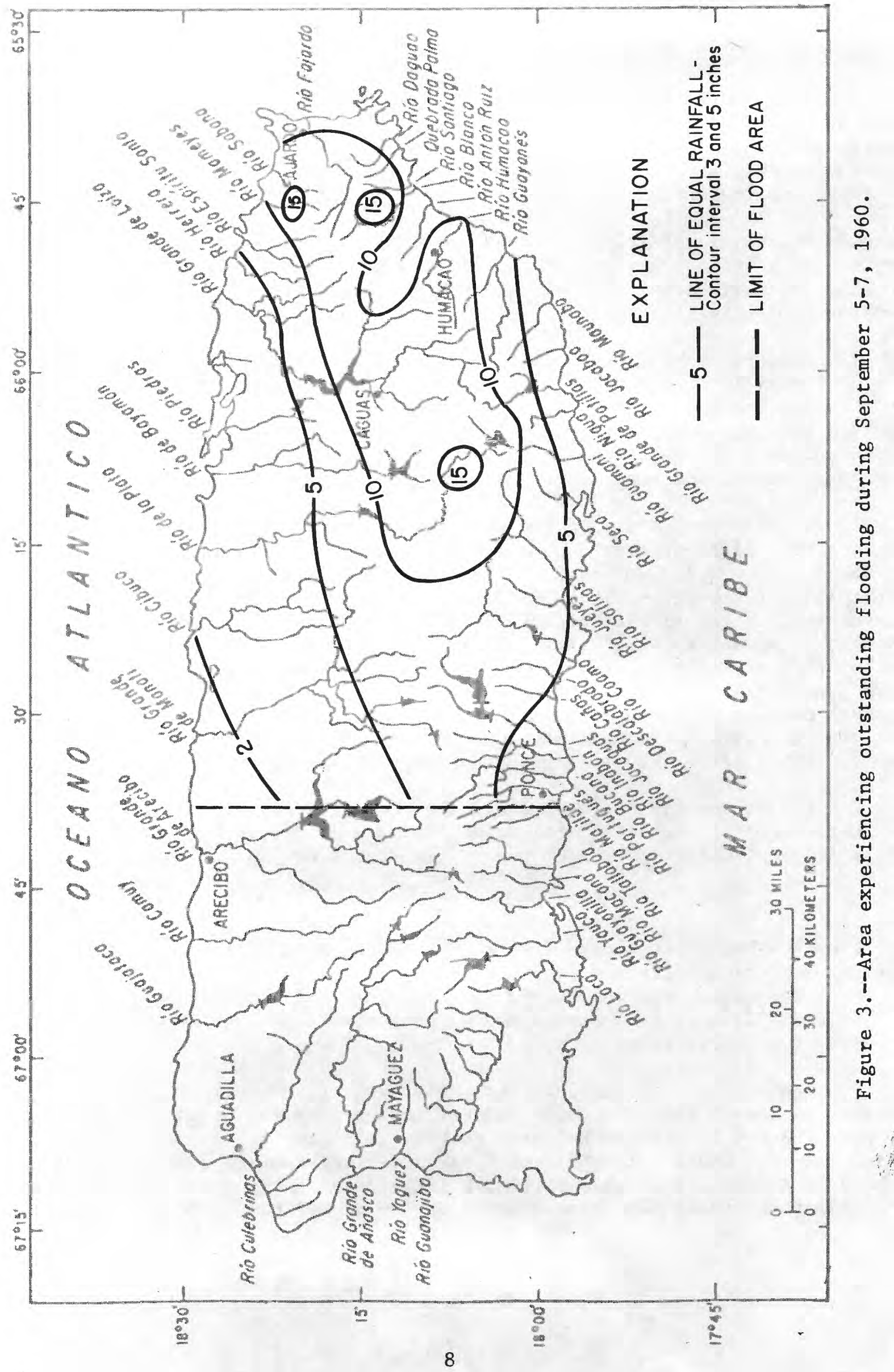




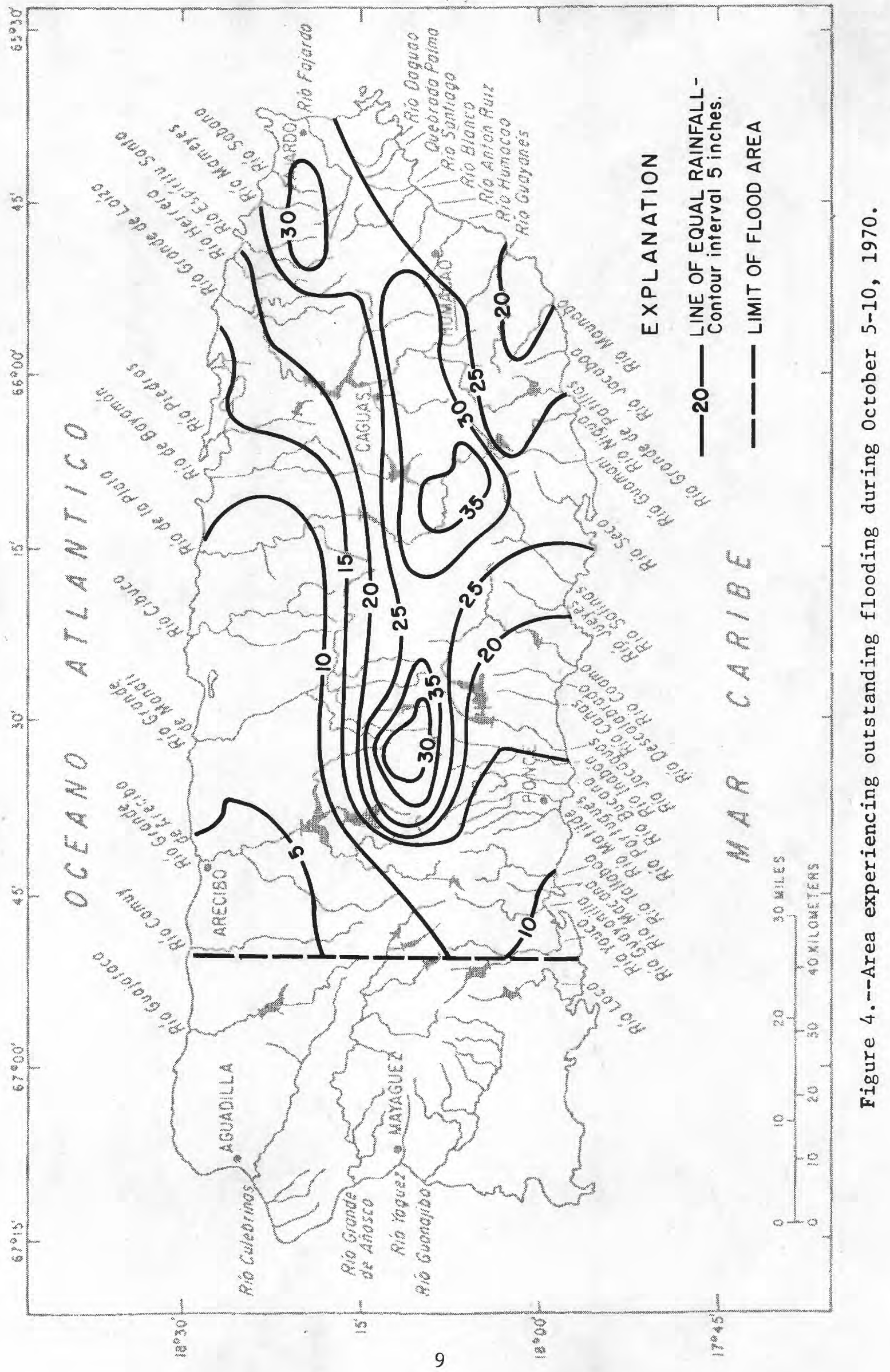




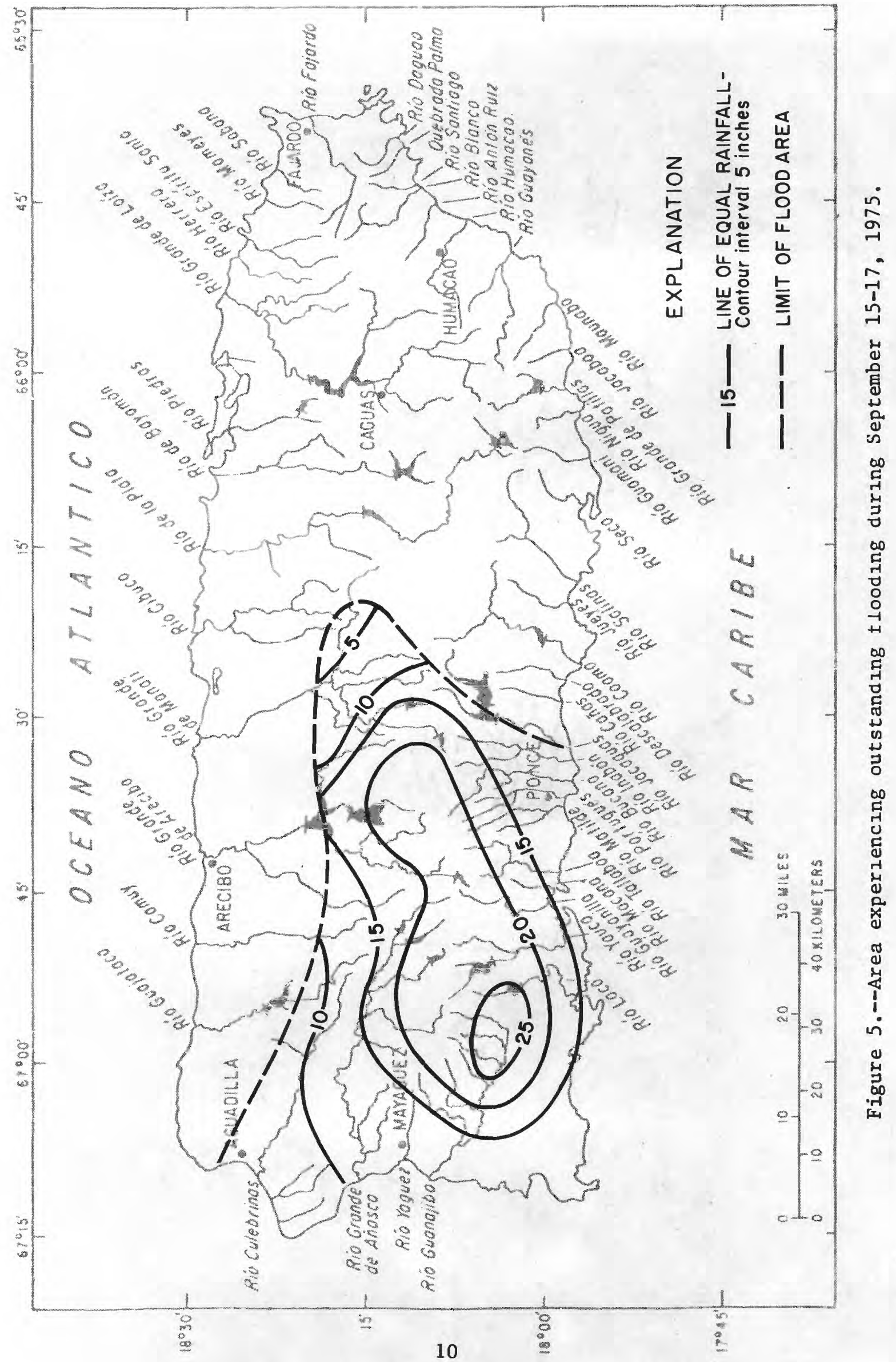


runoff collects and seldom reaches the stream as direct surface contribution. The contributing drainage area has been used as a correlative parameter in this report.

Much information about historical floods was taken from the U.S. Geological Survey Hydrologic Atlas series of flood inundation maps and bridge-site reports. The areas covered by flood studies and titles of the reports are shown in figure 6 and listed in table 1.

\section{FLOOD-FREQUENCY ANALYSES}

An analysis of flood frequency based on records collected at one gaging station is an indication of what has happened at that particular site during a specific period of time. Such a record is only a small sample of long-term flood characteristics, and therefore may not be a good basis for predicting what will happen in the future, even at that same site. A frequency curve based on regional characteristics of climate, topography, and other parameters is often believed to be more reliable than one solely based on flood experiences at a particular site. However, in order to derive a regional frequency curve, it is first necessary to define frequency curves for individual sites.

Frequency curves for individual stream sites were developed using the methods recommended and described in Water Resources Council Bulletin 17A (1977). The recommended method utilizes the $10 \mathrm{~g}$-Pearson Type III distribution. Methods are also described for checking for low data outliers and for utilizing historical peak flow data.

The skew coefficient in log-Pearson Type III analysis for short records is highly sensitive to extreme events. For this reason, it is sometimes recommended that a regional skew be used. There are inadequate data available to develop an accurate regional skew for Puerto Rico. However, a study of station skews indicated that a median skew for Puerto Rico was about 0.0 and there did not seem to be a trend in skew which could be related to geography or physiography. Therefore, to minimize the effects of the short record on the skew coefficient, a regional skew value of 0.0 was used in this analysis.

The supplemental data table lists the years and the peak flow data available for this study. Figure 7 shows in bar graph form, the years for which peak-flow data are available. Frequency curves were developed for 37 stream sites having 10 or more years of record. 


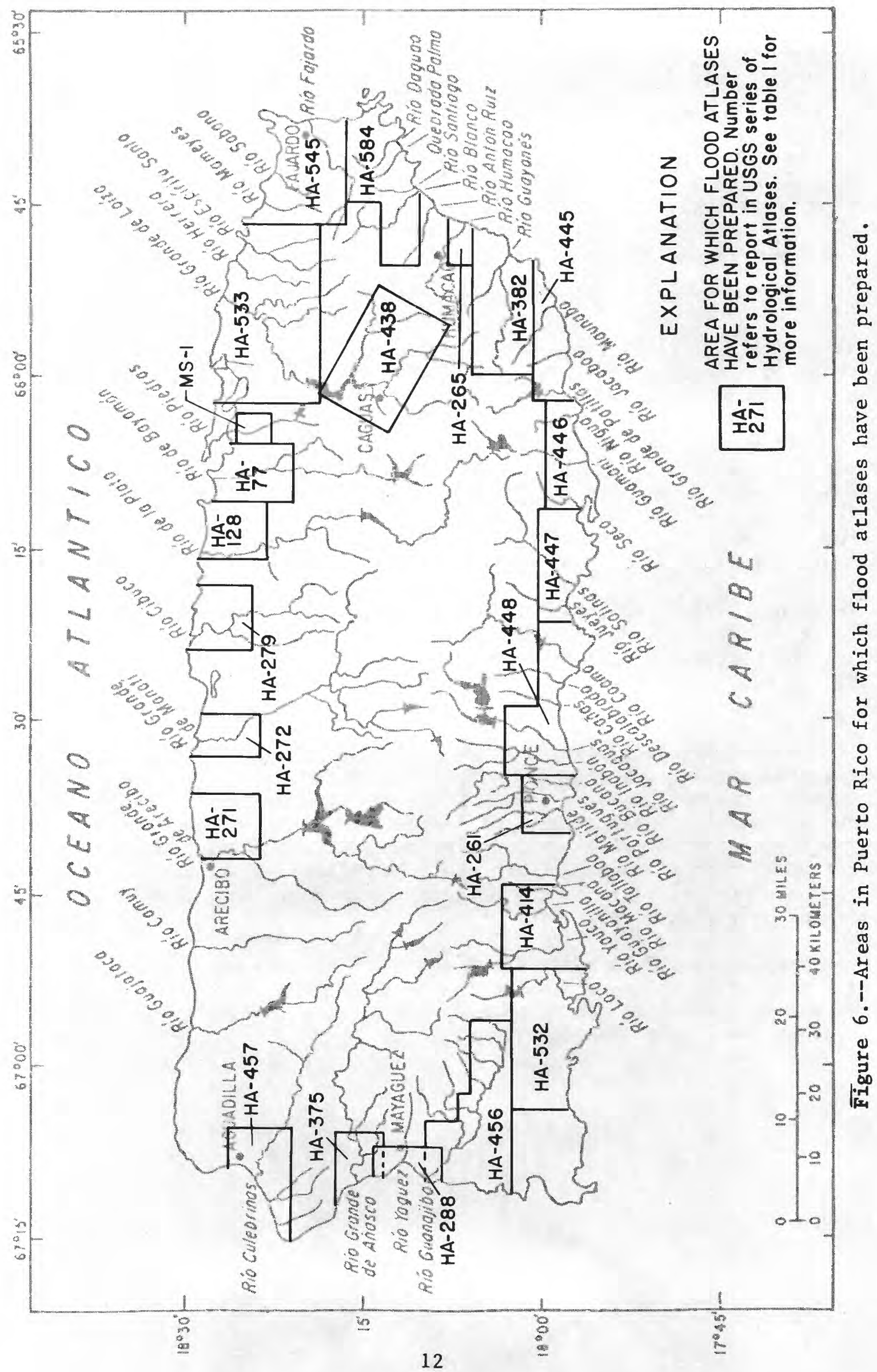




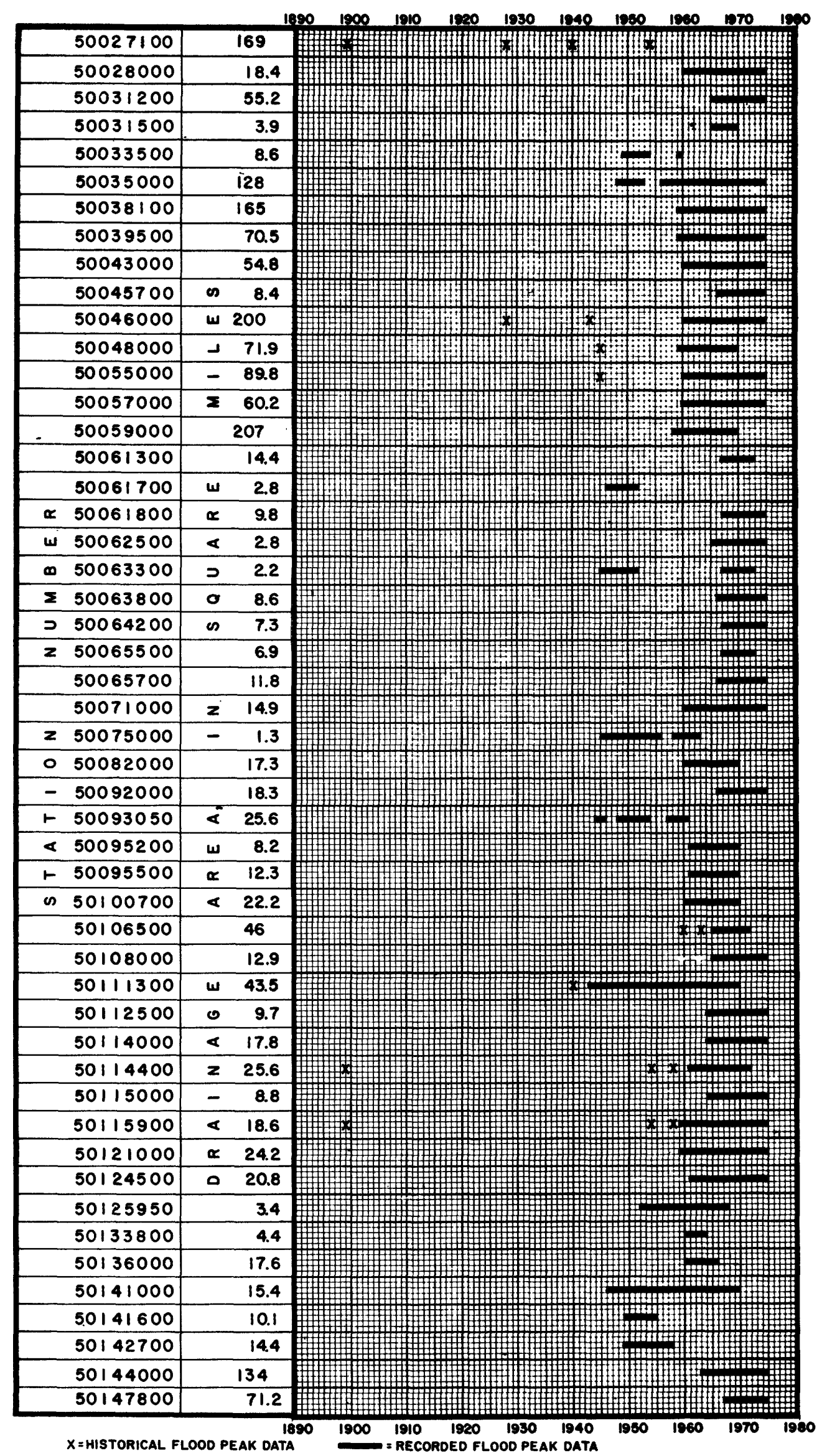

Figure 7.--List of annual peak discharge records in Puerto Rico for calendar years 1899 through 1975 . 
Table 1.--Hydrologic Investigations Atlases (Puerto Rico)

Number

Title and author

Published

HA-77 Floods at Bayamón and Cataño, Puerto Rico by M. A. López

1962

HA-128 Floods at Toa Alta, Toa Baja, and Dorado, Puerto Rico by M. A. López

1964

HA-261 Floods in the Ponce area, Puerto Rico by I. J. Hickenlooper and M. A. López

HA-262 Floods at Barceloneta and Manatí, Puerto Rico by

I. J. Hickenlooper

HA-265 Floods at Humacao, Puerto Rico by M. A. López

HA-271 Floods at Arecibo, Puerto Rico by I. J. Hickenlooper

1968

HA-288 Floods in the Mayaguez area of Puerto Rico by

I. J. Hickenlooper

1968

HA-289 Floods in the area of Vega Alta and Vega Baja, Puerto Rico by I. J. Hickenlooper

HA-375 Floods in the Añasco area, Puerto Rico by F. K. Fields

HA-382 Floods in the Yabucoa area, Puerto Rico by F. K. Fields

HA-414 Floods in the Guayanilla-Yauco area, Puerto Rico by

F. K. Fields

HA-430 Storm-wave swash along the north coast of Puerto Rico

by F. K. Fields and D. G. Jordan

HA-438 Floods at Caguas, Gurabo, Juncos, and San Lorenzo,

Puerto Rico by F. K. Fields

HA-445 Floods in Patillas-Maunabo area, Puerto Rico by W. J. Haire

HA-446 Floods in Guayama area, Puerto Rico by W. J. Haire

HA-447 Floods in Salinas area, Puerto Rico by W. J. Haire

HA-448 Floods in Santa Isabel area, Puerto Rico by W. J. Haire

HA-456 Floods in the Río Guanajibo valley, southwestern

Puerto Rico by W. J. Haire 
Table 1.--Hydrologic Investigations Atlases (Puerto Rico)--Continued

Number

Title and Author

Published

HA-457 Floods in the Aguadilla-Aguada area, northwestern

Puerto Rico by K. G. Johnson

1972

HA-532 Floods in the Lajas Valley, Puerto Rico by K. G. Johnson

1975

HA-533 Floods in the Carolina-Río Grande area, northeastern

Puerto Rico by W. J. Haire

1975

HA-545 Floods in the Fajardo-Luquillo area, northeastern

1975

Puerto Rico by W. J. Haire

HA-584 Floods in the Naguabo area, eastern Puerto Rico

1978

by W. J. Haire

MS-1 Flooding along the Río Piedras in the San Juan area,

1972 Puerto Rico by $W$. J. Haire

\section{REGIONAL ANALYSIS}

After individual station frequency curves were developed, results were regressed against basin parameters that can be measured from topographic and rainfall maps and soil data that can be retrieved from the Puerto Rico Department of Natural Resources' "Mapa de Inventario de Recursos Naturales, Culturales y Ambientales, 1974."

Records at stations downstream from certain reservoirs were used in the regional analysis for the period of record, even though some regulation was in effect. Generally, reservoir operation data during peaks was incomplete or missing altogether. Therefore, it is impossible to fully determine the effect of the reservoirs on downstream peak flows.

The effect on peak flows would definitely be significant in some instances if the reservoirs become nearly empty prior to a peak-flow producing storm. It is believed that the reservoirs usually are not allowed to be reduced to nearempty levels. Therefore, it was assumed that the storage had little effect on peak flows at the following stations and the unadjusted peak-flow analysis was used in the regional regression analysis. 


\begin{tabular}{|c|c|c|c|c|c|}
\hline $\begin{array}{l}\text { Station } \\
\text { number }\end{array}$ & River & Reservoir & $\begin{array}{c}\text { Date regu- } \\
\text { lation } \\
\text { began }\end{array}$ & $\begin{array}{l}\text { Usable } \\
\text { storage } \\
\text { (acre-ft) }\end{array}$ & $\begin{array}{l}\text { Date of } \\
\text { contents } \\
\text { survey }\end{array}$ \\
\hline $\begin{array}{lll}50 & 0350 & 00\end{array}$ & $\begin{array}{l}\text { Río Grande de } \\
\text { Manatí }\end{array}$ & Matrullas & 1934 & 2,400 & 1934 \\
\hline & & Guineo & 1931 & 1,810 & 1931 \\
\hline 043000 & $\begin{array}{l}\text { Río Grande de } \\
\text { la Plata }\end{array}$ & Carite & 1913 & 9,800 & 1913 \\
\hline 046000 & $\begin{array}{l}\text { Río Grande de } \\
\text { la Plata }\end{array}$ & Carite & 1913 & 9,800 & 1913 \\
\hline & & La Plata & 1973 & 55,900 & 1974 \\
\hline 144000 & $\begin{array}{l}\text { Río Grande de } \\
\text { Añasco }\end{array}$ & Yahuecas & 1956 & 1,800 & 1956 \\
\hline & & $\begin{array}{l}\text { Guayo } \\
\text { Prieto }\end{array}$ & $\begin{array}{l}1956 \\
1955\end{array}$ & $\begin{array}{r}17,400 \\
1,800\end{array}$ & $\begin{array}{l}1956 \\
1955\end{array}$ \\
\hline
\end{tabular}

Regulation from reservoirs on the following streams was considered to be large enough to affect peak flows. Therefore, based on reservoir stage observations and records of reservoir outflows, determinations were made of peak inflows to the reservoirs. These determinations of peak inflow were then analyzed for flood frequencies and the results used in the regional regression analysis. Reservoir inflow data were used for the following stations:

50059000 Río Grande de Loíza at Lago Loíza

093050 Río Grande de Patillas at Lago Patillas

111300 Río Jacaguas at Lago Guayabal

Because these reservoirs are not operated for flood control, they are allowed to fill before controlled releases are made. This method of operation generally results in reduced discharges downstream from the dam for the lesser frequency floods, but provides very little reduction in the larger floods which peak after the reservoir has filled. An analysis of inflow and outflow peak discharges at Lago Loiza Dam indicates the outflow peak discharge is not significantly reduced for floods of 50-year or greater recurrence intervals. Differences in the inflow and outflow frequency curves are shown in U.S. Geological Survey Hydrologic Investigations Atlas HA-533 (Haire, 1975).

The regression equations for less than the 50-year flood, generally do not apply below the larger reservoirs in Puerto Rico. However, since most reservoirs are fairly small relative to the volumes of flow occurring during major storm events, the equations should be applicable below most reservoirs. The degree of effect of regulation will be lessened as the flood magnitude increases. Therefore, while the peak-flow equation will perhaps not be applicable for a more frequent or smaller peak flow, the equation for a higher peak flow will more likely be applicable. 


\section{Basin Characteristics}

Many basin characteristics were tested in the regression analyses with the gaged site T-year peaks, but only a few proved to be significant in the final equation. Those tested are described as follows:

1. Drainage area (a), in square miles: determined by outlining the basin on 1:20,000 U.S. Geological Survey topographic quadrangles and planimetering the area within the outline. Closed basins within the outline with no apparent surface drainage connection to the stream were not included.

2. Channel slope (S), in meters per kilometer: measured along the main channel from the first contour that crosses the channel downstream from the gage to the next contour that crosses the channel upstream from the gage. One was added to the result to avoid negative logs of numbers less than one.

3. Ground slope (GS), in percent: data retrieved from the Puerto Rico Department of Natural Resources "Mapa de Inventario de Recursos Naturales, Culturales y Ambientales (1974)." The average of the ground slope of all $1 / 4-\mathrm{km}^{2}$ cells within the basin boundary was computed from the retrieval program DATALIST.

4. Permeability (Perm), in inches per hour: data retrieved from the Puerto Rico Department of Natural Resources "Mapa de Inventario de Recursos Naturales, Culturales y Ambientales (1974)." The average of the permeability of all $1 / 4-\mathrm{km}^{2}$ cells within the basin boundary was computed from the retrieval program DATALIST. The reciprocal of this value was used in the multiple regression to avoid the negative logarithm of values less than one.

5. Depth to rock (D), in feet: data retrieved from the Puerto Rico Department of Natural Resources "Mapa de Inventario de Recursos Naturales, Culturales y Ambientales (1974)." The average depth to rock of all $1 / 4-\mathrm{km}^{2}$ cells within the basin boundary was computed from the retrieval program DATALIST.

6. Forest cover (F), in percent: data retrieved from the Puerto Rico Department of Natural Resources "Mapa de Inventario de Recursos Naturales, Culturales y Ambientales (1974)." The number of $1 / 4-\mathrm{km}^{2}$ cells that are over 50 percent forested was divided by the total number of cells within the basin boundary and the result multiplied by 100 .

7. Annual precipitation (Ann $\mathrm{P}$ ), in inches: weighted mean annual precipitation over the basin computed from figure 2 adapted from "Climatology of the United States" (U.S. Department of Commerce, 1965, revised May 1969).

8. Rainfall intensity, 24-hour, 25-year recurrence interval $\left(\mathrm{I}_{24-2}\right)$, in inches: weighted 24-hour, 2-year recurrence interval rainfall over the basin upstream from the gage was computed from figure 4-50 of the U.S. Weather Bureau Technical Paper no. 42 (U.S. Department of Commerce, 1961). 
9. Rainfall intensity, 24-hour, 25-year recurrence interval $\left(\mathrm{I}_{24-25}\right)$, in inches: weighted 24-hour, 25-year recurrence interval rainfall over the basin upstream from the gage was computed from figure 4-53 of the U.S. Weather Bureau Technical Paper no. 42 (U.S. Department of Commerce, 1971).

Note: A high correlation exists between the 24-hour, 25-year recurrence interval rainfall and the 24-hour, 50- and 100-year recurrence interval rainfalls. Therefore, only the 2-year and 25-year recurrence interval rainfalls were used in the regressions.

\section{Regression Analyses}

A step-backward regression analysis using $\log$ transforms of the 2-, 10-, 25-, 50- and 100-year recurrence interval floods was regressed against log transforms of the basin characteristics. All the data for 50 gaging stations with 5 or more years of annual peak-discharge record were initially used. The ratio of $\left(Q_{50}\right.$ Observed $) /\left(Q_{50}\right.$ Regression) using drainage area as the independent variable was plotted at the center of each basin on a map of the island. No apparent regional pattern was evident. The significant basin characteristics were the drainage area and annual precipitation. All other basin characteristics tested did not reduce the error of estimate significantly at the 95-percent level.

Selected station records with 10 or more years of record were used in the next regression trial. Residuals of the 25-year flood at each basin using drainage area and annual precipitation as independent variables were again plotted on a map to identify any regional pattern. The ratio of $\left(Q_{25}\right.$ Observed $) /\left(Q_{25}\right.$ Regression) varied randomly throughout the island, ranging from 0.38 to 2.07 .

Final regression equations determined from the analyses of 37 station records with 10 or more years are as follows:

$$
\begin{aligned}
& Q_{2}=0.033 A^{.776}(\text { Ann } P)^{2.11} S_{R}=+51,-34 \text { percent } \\
& Q_{10}=3.72 A^{.822}(\text { Ann P })^{1.29} S_{R}=+45,-31 \text { percent } \\
& \mathrm{Q}_{25}=25.7 \mathrm{~A}^{.826}(\text { Ann } \mathrm{P})^{.953} \mathrm{SE}_{\mathrm{R}}=+50,-33 \text { percent } \\
& Q_{50}=89.9 A^{.830}(\text { Ann } P)^{.734} S_{R}=+55,-36 \text { percent } \\
& Q_{100}=286 A^{.832}\left(\text { Ann P) } .531 \quad S_{R}=+61,-38\right. \text { percent }
\end{aligned}
$$


where

A is the drainage area in square miles,

Ann $\mathrm{P}$ is the weighted mean annual precipitation in inches, and

$\mathrm{SE}_{\mathrm{R}}$ is the standard error of the regression equation.

These equations are for use with inch-pound units only.

The above equations may not be applicable on streams where large reservoirs exist. This was discussed in more detail earlier. Also, the equations do not take into consideration the storage of water on large overflow plains which may significantly reduce the peak flow. The equations are not appropriate where a significant part of the basin is urbanized. Use of the equations for drainage areas less than those used in this analysis may tend to give erroneous results.

Multiple-regression results using records through December 1969 (López and Fields, 1970) are compared in the following tabulation with multiple-regression equations using records through December 1975.

\begin{tabular}{|c|c|c|c|}
\hline \multicolumn{3}{|c|}{$\begin{array}{l}\text { Data through } 1969 \\
\text { Record } \geq 5 \text { years }\end{array}$} & $\begin{array}{l}\text { Data through } 1975 \\
\text { Record } \geq 10 \text { years }\end{array}$ \\
\hline Equation & $\begin{array}{c}\mathrm{SE}_{\mathrm{R}} \\
\text { (percent) }\end{array}$ & Equation & $\underset{\text { (percent) }}{\mathrm{SE}_{\mathrm{R}}}$ \\
\hline $\mathrm{Q}_{2}=43.9 \mathrm{~A}^{.49}(\text { Ann } \mathrm{P}-50)^{.28}$ & 35 & $\mathrm{Q}_{2}=0.033 \mathrm{~A}^{.776}(\text { Ann P })^{2.11}$ & $+51,-34$ \\
\hline$Q_{10}=2230 \mathrm{~A}^{.60}$ & 35 & $Q_{10}=3.72 \mathrm{~A}^{.822}(\text { Ann } \mathrm{P})^{1.29}$ & $+45,-31$ \\
\hline$Q_{25}=2840 \mathrm{~A}^{.66}$ & 34 & $Q_{25}=25.7 A^{.826}($ Ann P) $\cdot 953$ & $+50,-33$ \\
\hline$Q_{50}=3230 \mathrm{~A}^{\cdot 71}$ & 34 & $Q_{50}=89.9 A^{.830}($ Ann P $) \cdot 734$ & $+55,-36$ \\
\hline & & $Q_{100}=268 A .832($ Ann $P) \cdot 531$ & \\
\hline
\end{tabular}

\section{Accuracy of Regionalized T-Year Flood Event}

Although the standard error of estimate of the regression gives an approximation of the standard error of the flow characteristic, the standard error of prediction is a better parameter for evaluating accuracy of the regression equation. As shown by Matalas and Gilroy (1968), the accuracy of a prediction depends in part on how much of the standard error of estimate is due to timesampling error (error in the characteristic at the stations used in the regression) and how much is due to error in the underlying relation between the true values of the flow characteristics. Hardison (1971) evaluated the equations proposed by Matalas and Gilroy (1968) and presented a method of converting the standard error of estimate of the regression to a standard error of prediction at ungaged sites. 
As the standard error of prediction of a streamflow characteristic depends largely on the variability of the annual events, it tends to vary widely from one region to another. One way to remove the bias in evaluating the accuracy of a prediction equation is to express it in terms of the equivalent years of record that would be required to give results of equal accuracy at an individual site. This concept of equivalent-year accuracy was used in the design of streamflow data programs (Carter and Benson, 1969). Equations for converting standard error of prediction to accuracy in equivalent years of record for the regression equation selected were computed using the method proposed by Hardison (1971). An average interstation correlation coefficient of 0.25 was assumed for the computation of the standard error of prediction and of the equivalent years of record.

The standard error of prediction, $\mathrm{SE}_{\mathrm{p}}$, and the equivalent length of record for the regression equations are as follows:

\begin{tabular}{clccc}
\hline Equation & T-year flood equation & $\begin{array}{c}S_{\mathrm{p}} \\
\text { (percent) }\end{array}$ & $\begin{array}{c}\text { Equivalent years } \\
\text { of record }\end{array}$ \\
\hline 1 & $Q_{2}=0.033 \mathrm{~A}^{.776}$ (Ann P) .211 & $+48,-32$ & 5 \\
2 & $\mathrm{Q}_{10}=3.72 \mathrm{~A}^{.882}$ (Ann P) ${ }^{1.29}$ & $+36,-27$ & 15 \\
3 & $\mathrm{Q}_{25}=25.7 \mathrm{~A}^{.826}$ (Ann P) .953 & $+38,-28$ & 19 \\
4 & $\mathrm{Q}_{50}=89.9 \mathrm{~A}^{.830}$ (Ann P) .734 & $+42,-29$ & 20 \\
5 & $\mathrm{Q}_{100}=286 \mathrm{~A}^{.832}$ (Ann P) .531 & $+46,-32$ & 20 \\
\hline
\end{tabular}

\section{DETERMINATION OF FLOOD MAGNITUDE AND FREQUENCY}

\section{Ungaged Sites}

The expected magnitude of selected frequency floods can be computed, using equations $1-5$ as defined in the previous section. Since the solution to these equations involves only two independent variables, drainage area (A) and mean annual precipitation (Ann $P$ ), a set of diagrams can be used to determine the peak discharge. These diagrams are in figures 8-12.

An example of the use of these diagrams follows for Rio Valenciano at Highway 30 at Juncos. Assume a 50-year recurrence interval flood-peak discharge is required for the design of a new bridge on Highway 30 . The pertinent basin characteristics needed are:

$$
\begin{aligned}
& \text { drainage area }(A)=18.6 \mathrm{mi}^{2}\left(48.2 \mathrm{~km}^{2}\right) \\
& \text { weighted mean annual precipitation (Ann P) }=92 \text { in }(2,337 \mathrm{~mm} \text { ) }
\end{aligned}
$$

Enter the diagram in figure 11 at $18.6 \mathrm{mi}^{2}$ on the horizontal scale, draw a line vertically to six-tenths the distance between the 80- and 100-in (Ann P) diagonal lines and then draw a line horizontally to the peak discharge scale. Read the peak discharge of $28,100 \mathrm{ft}^{3} / \mathrm{s}$. 


\section{Gaged Sites}

Log-Pearson Type III flood-frequency curve discharge values were determined at 50 sites with 5 or more years of annual peak record. The computed peak discharges for 2-, 10-, 25-, 50- and 100-year recurrenceinterval floods at each of these sites are given in table 2. Also listed are the drainage area (A) and weighted mean annual precipitation (Ann P) for each site. These two basin characteristics can be used to determine the selected recurrence interval flood-peak discharge using figures. 8-12. The peak discharge computed at the site using the basin parameters can be compared with the peak discharge derived from the individual station record.

For example, assume a flood-control channel is proposed for Río Grande de Manati from Highway 2 to the ocean. The design flood capacity of the channe1 should carry at least the 100-year recurrence interval peak discharge. A record of annual peak discharges for 17 years is available at station 500381 00, Río Grande de Manatí at Highway 2 near Manatí. The log-Pearson Type III frequency curve magnitude for 100 years at this site is found in table 2 and is equal to $255,000 \mathrm{ft}^{3} / \mathrm{s}\left(7,220 \mathrm{~m}^{3} / \mathrm{s}\right)$.

To compare this estimate of the 100-year flood determined from the record at the site with the regression estimate, use figure 12 with the area (A) $=165 \mathrm{mi}^{2}\left(427 \mathrm{~km}^{2}\right)$ and the weighted mean annual precipitation (Ann $\mathrm{P}$ ) = 84 in $(2,134 \mathrm{~mm})$. The regression result is $210,000 \mathrm{ft}^{3} / \mathrm{s}(5,950 \mathrm{~m} 3 / \mathrm{s})$.

The U.S. Water Resources Council (Appendix 8, 1977) recommends that the logarithms of the discharge be weighted by the appropriate equivalent years of record to estimate the frequency characteristics at a site where both regiona1ized and site information are available. The equation that is used to determine the best estimate of the T-year flood is:

$$
\log \mathrm{Q}_{\mathrm{T}}=\frac{\mathrm{N}_{1} \log \mathrm{Q}_{\mathrm{S}}+\mathrm{N}_{2} \log \mathrm{Q}_{\mathrm{R}}}{\mathrm{N}_{1}+\mathrm{N}_{2}}
$$

where $Q_{T}$ is the discharge of the $T$-year flood peak

$\mathrm{Q}_{\mathrm{S}}$ is the T-year discharge determined by site data

$Q_{R}$ is the $T$-year discharge determined by regionalized data

$\mathrm{N}_{1}$ is the years of record at the site and

$\mathrm{N}_{2}$ is the equivalent years of record represented by the regional equation.

The data for station 50038100 on the Río Grande de Manati are used as an example. The 100-year flood determined from site data is $255,000 \mathrm{ft} / \mathrm{s}$ $\left(7,220 \mathrm{~m}^{3} / \mathrm{s}\right)$ and that by the regionalized data is $210,000 \mathrm{ft}^{3} / \mathrm{s}\left(5,950 \mathrm{~m}^{3} / \mathrm{s}\right)$. 


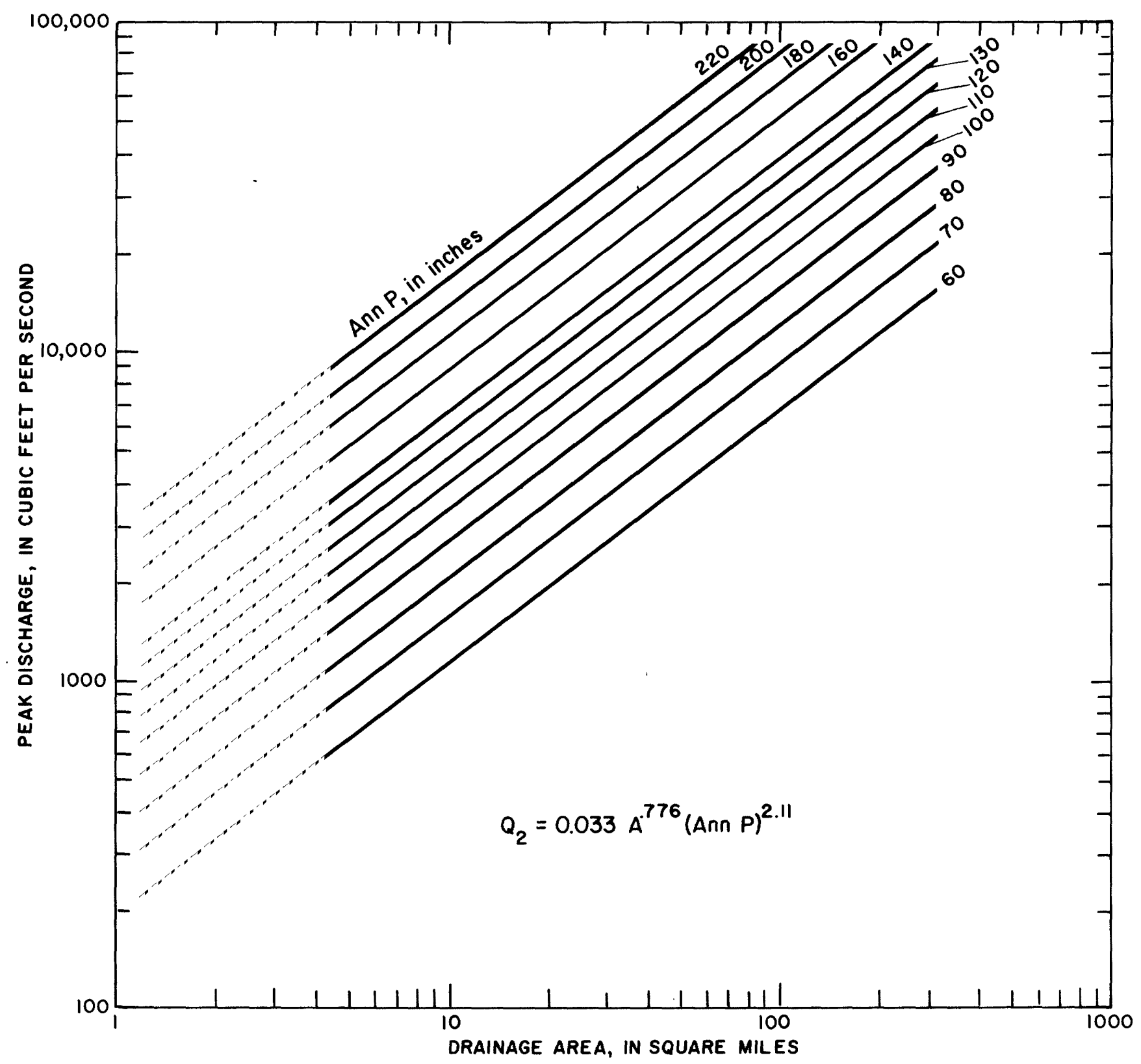

Figure 8.--Diagram for determining the 2-year flood-peak discharge at ungaged sites in Puerto Rico. 


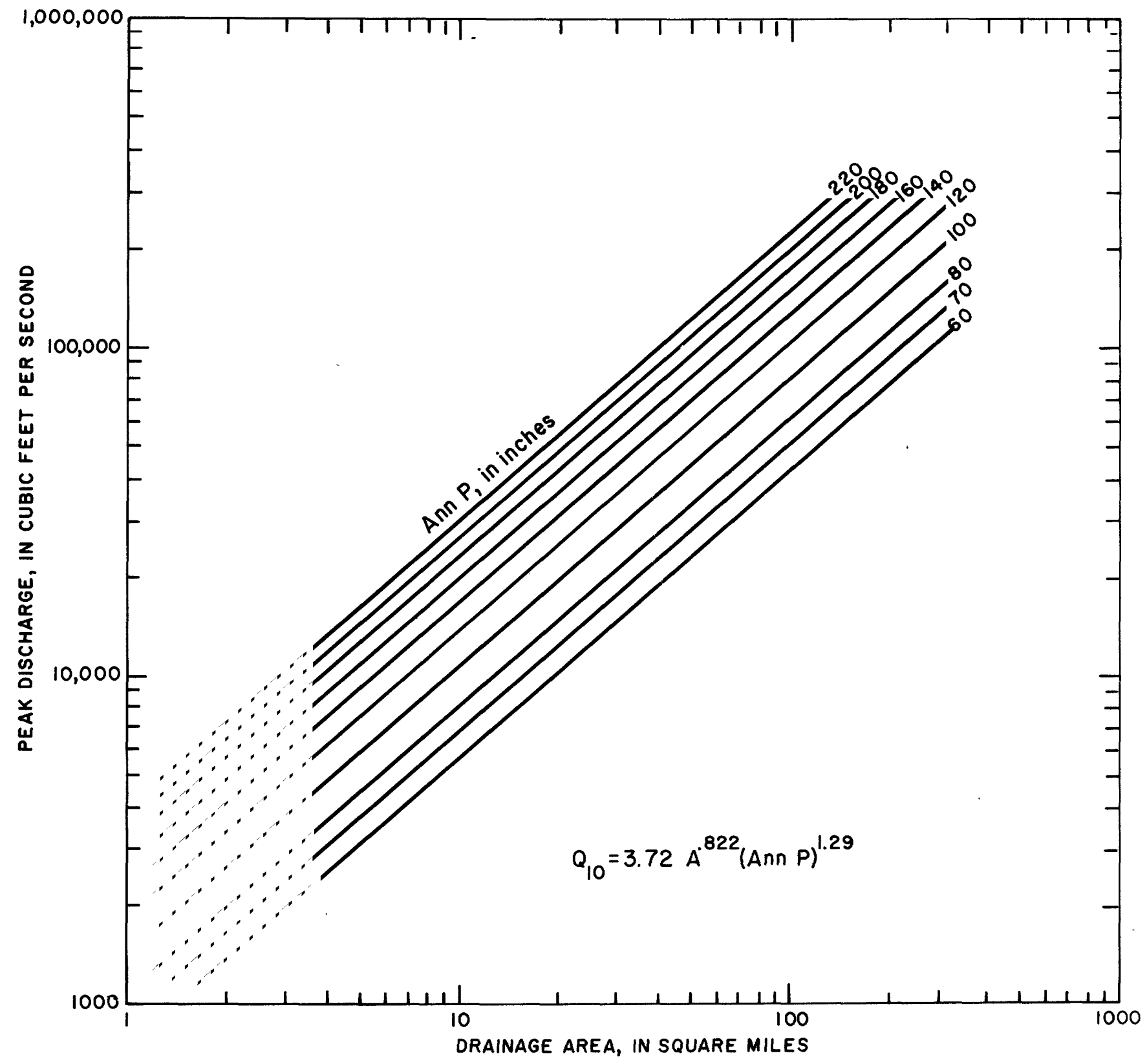

Figure 9.--Diagram for determining the 10-year flood-peak discharge at ungaged sites in Puerto Rico. 


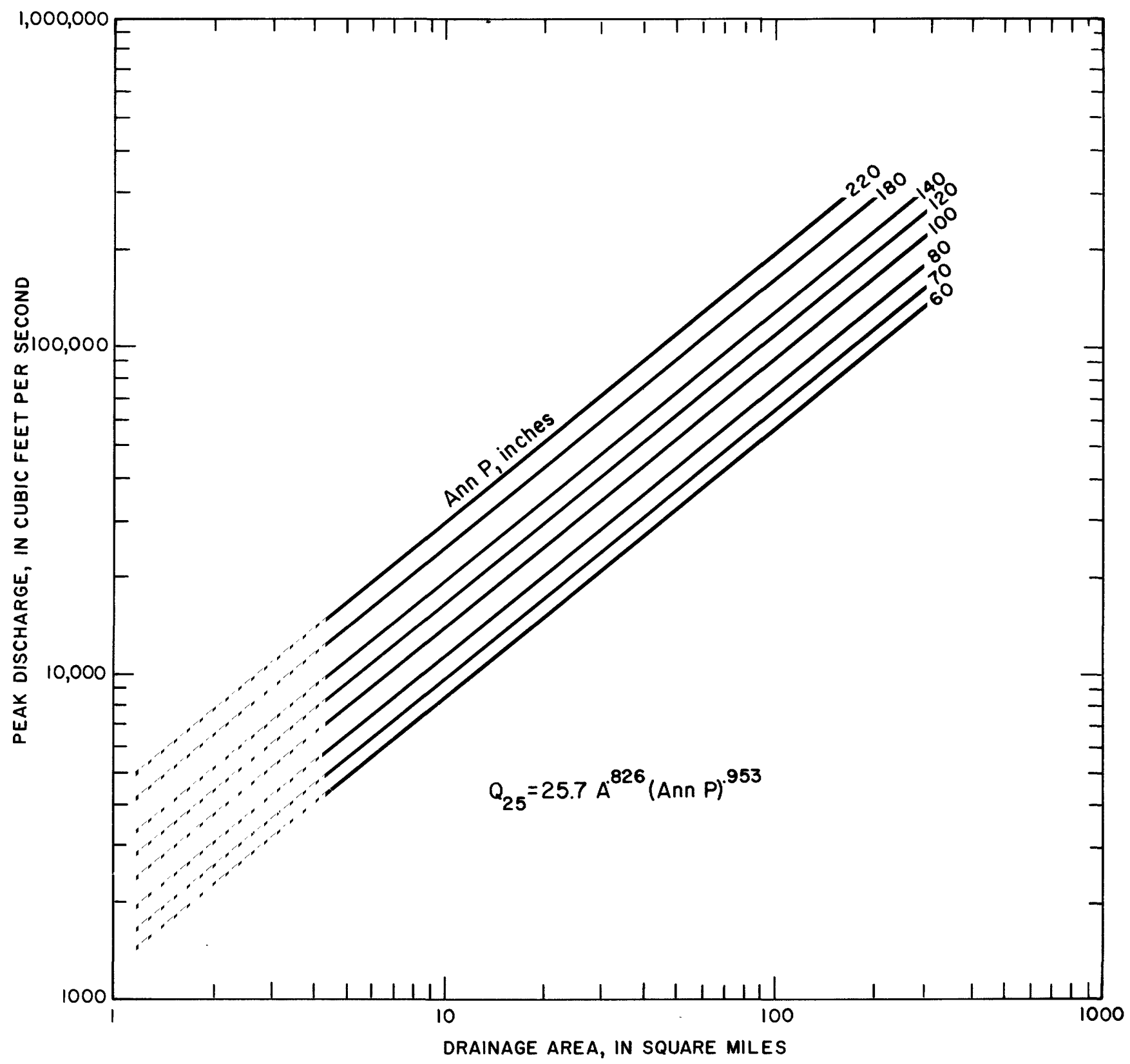

Figure 10.-Diagram for determining the 25-year flood-peak discharge at ungaged sites in Puerto Rico. 


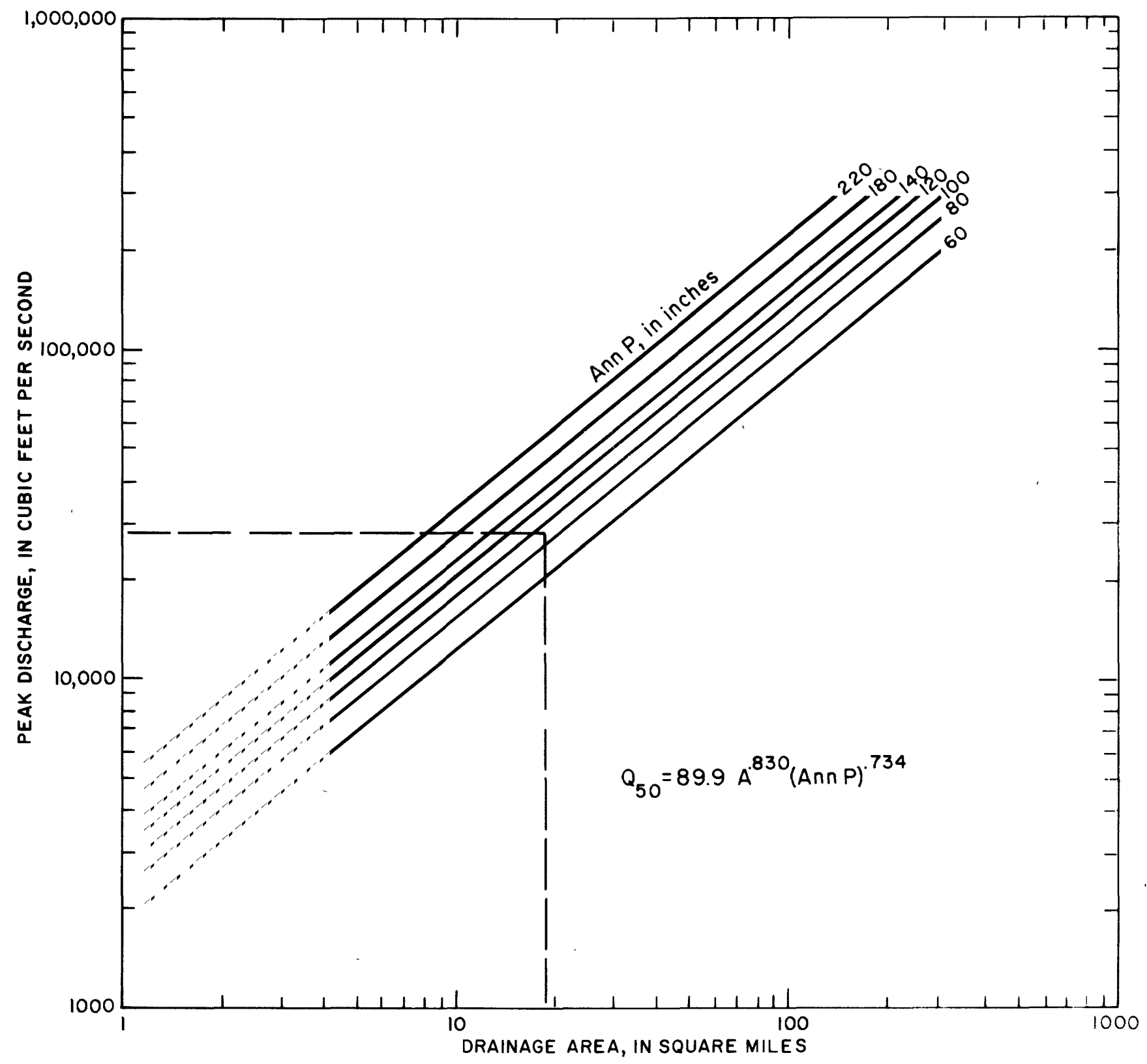

Figure 11.--Diagram for determining the 50-year flood-peak discharge at ungaged sites in Puerto Rico. 


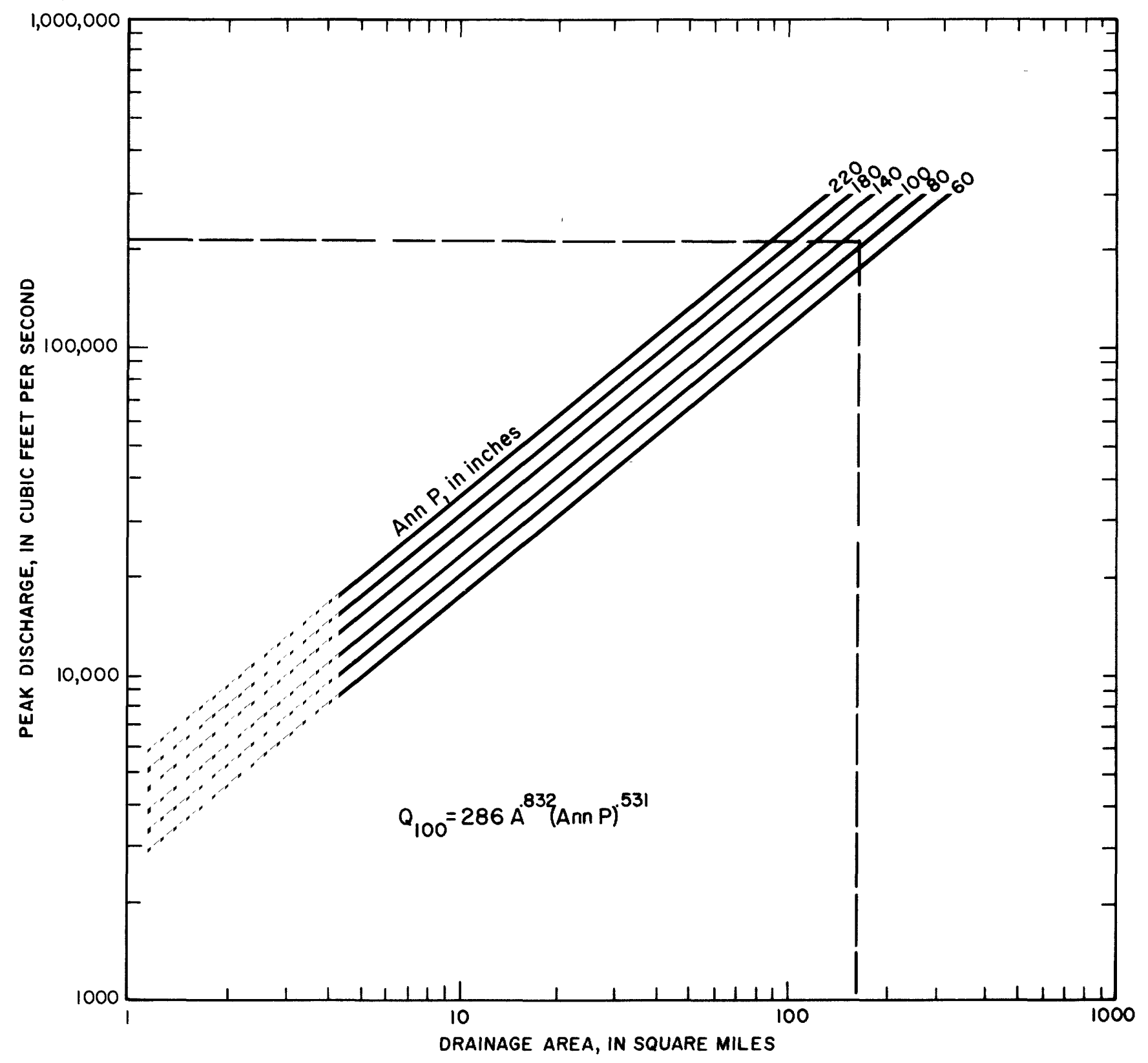

Figure 12.--Diagram for determining the 100-year flood-peak discharge at ungaged sites in Puerto Rico 
The site data are based on 17 years of record and we have determined that the regional data for the 100-year flood are equivalent to 20 years of record. The estimated of the 100-year flood for this site is then computed as follows:

$$
\begin{aligned}
\log Q_{100} & =\frac{17 \log 255,000+20 \log 210,000}{17+20}=5.3610 \\
Q_{100} & =230,000 \mathrm{ft}^{3} / \mathrm{s}\left(6,510 \mathrm{~m}^{3} / \mathrm{s}\right) .
\end{aligned}
$$

For sites near gaged sites and on the same stream, flood-frequency data can be estimated by transferring the nearby station data to the ungaged site and weighting with the regression data for the ungaged site.

The following procedure can be used if the site has a drainage area within 50 percent of the gaged site. The station value can be transferred upstream or downstream by the equation.

$$
\mathrm{Qu}=\left(\frac{\mathrm{Au}}{\mathrm{Ag}}\right)^{\mathrm{n}} \mathrm{Q}_{\mathrm{T}}
$$

where

$\mathrm{Qu}$ is the transferred discharge at the ungaged site

$\mathrm{Au}$ is the drainage area of the ungaged site

$\mathrm{Ag}$ is the drainage area of the gaged site

$\mathrm{n}$ is the exponent for the drainage area for the appropriate $T$-year regional regression equation and

$\mathrm{Q}_{\mathrm{T}}$ is the weighted $\mathrm{T}$-year flood discharge at the nearby gaged site and a weighted value can be computed by the equation

$$
\mathrm{Q}_{\mathrm{W}}=\left(\frac{2 \Delta \mathrm{A}}{\mathrm{Ag}}\right) \quad \mathrm{Q}_{\mathrm{R}}+\left(1-\frac{2 \Delta \mathrm{A}}{\mathrm{Ag}}\right) \mathrm{Q}_{\mathrm{u}}
$$

where

$\mathrm{Q}_{\mathrm{W}}$ is the weighted $\mathrm{T}$-year flood discharge at the ungaged site

$\Delta \mathrm{A}$ is the difference between the drainage areas of the gaged and ungaged site

$\mathrm{Ag}$ is the drainage area of the gaged site

$\mathrm{Q}_{\mathrm{R}}$ is the $\mathrm{T}$-year discharge determined by regionalized data

$Q_{u}$ is the transferred discharge at the ungaged site. 


$$
\begin{aligned}
& \text { ख્త }
\end{aligned}
$$

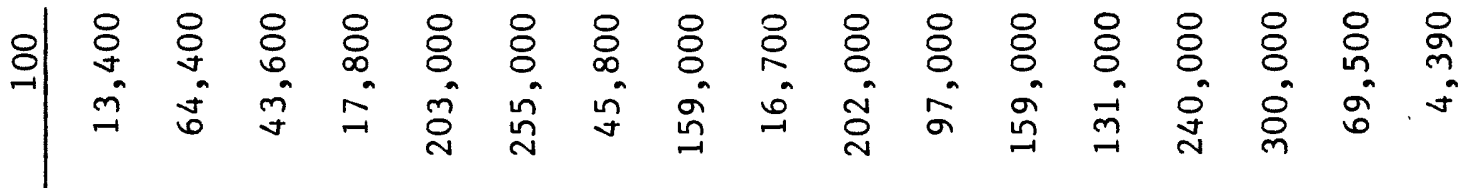

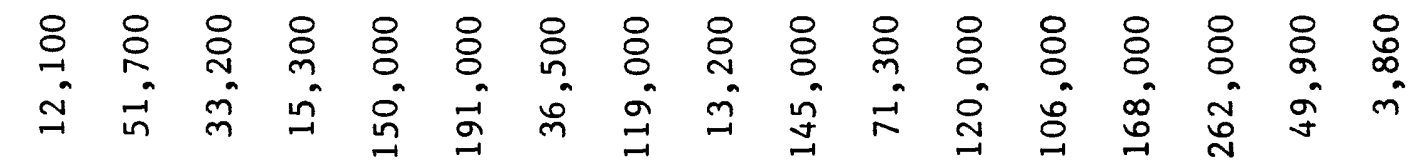

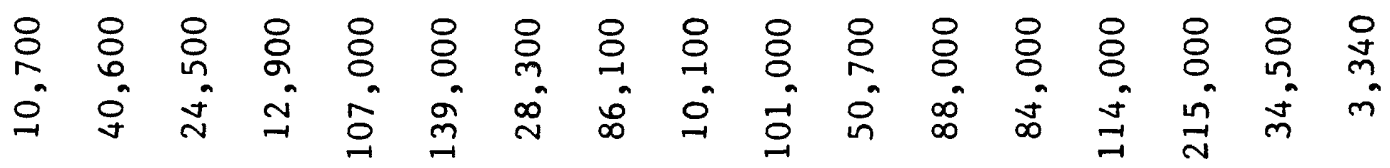

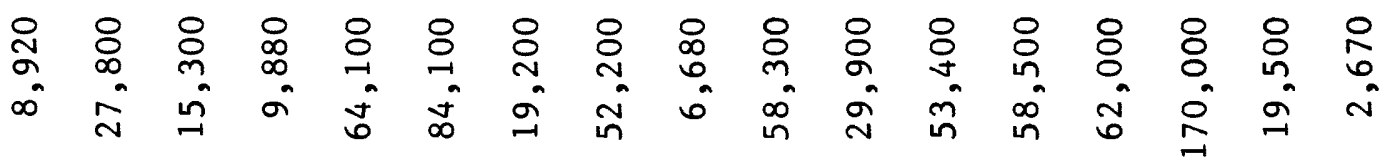

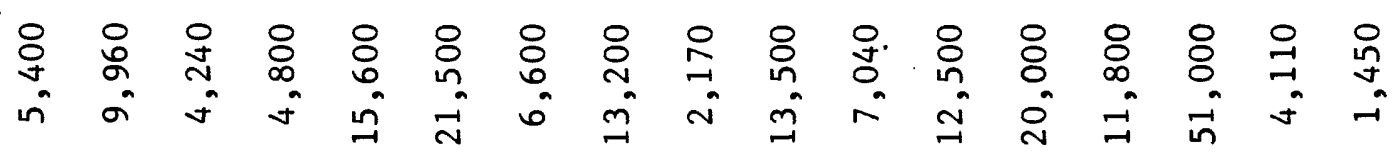

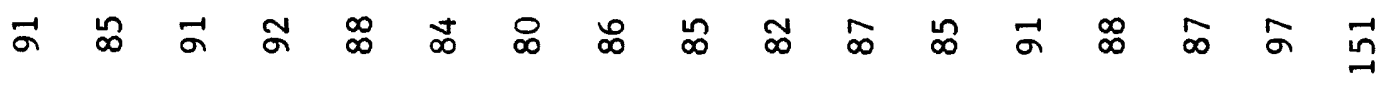

$$
\begin{aligned}
& \text { क्ष 귱 }
\end{aligned}
$$

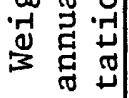

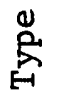

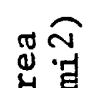

$$
\begin{aligned}
& \text { 旡管 }
\end{aligned}
$$

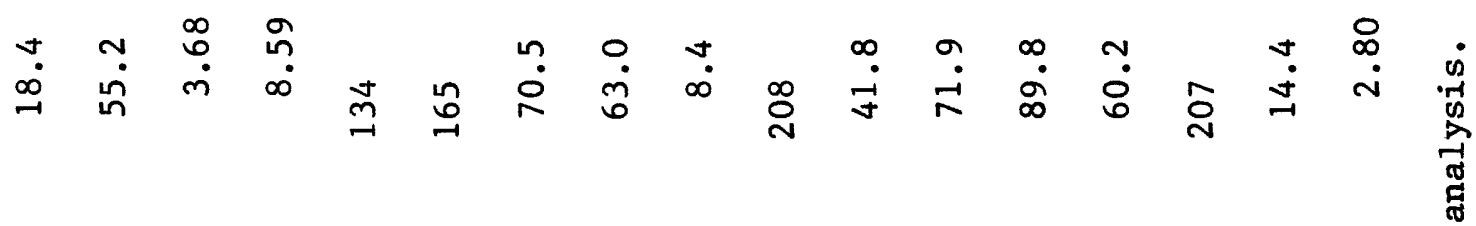

$$
\begin{aligned}
& \text { 㟧 } \overparen{0}
\end{aligned}
$$

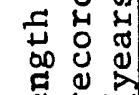

$$
\begin{aligned}
& \text { 离出 }
\end{aligned}
$$

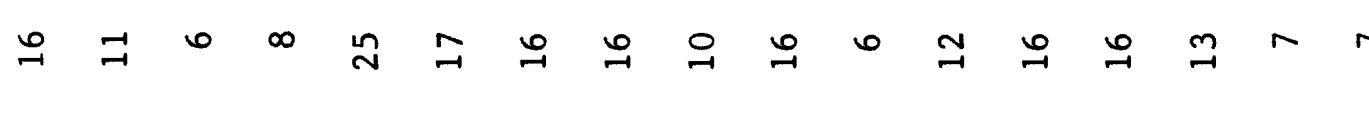

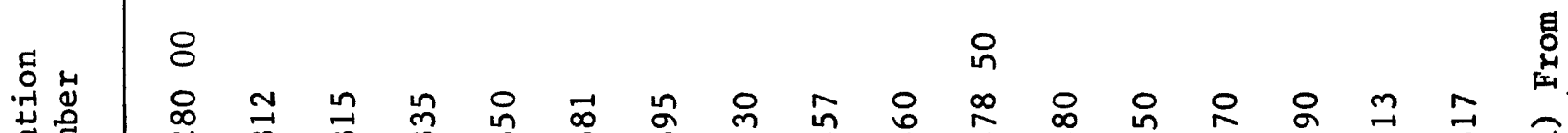

$$
\begin{aligned}
& \text { 岕宫 }
\end{aligned}
$$

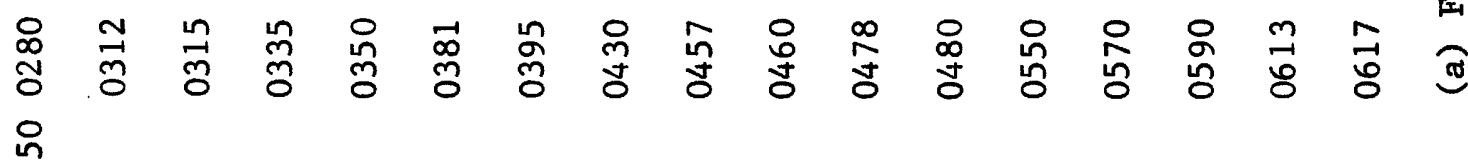




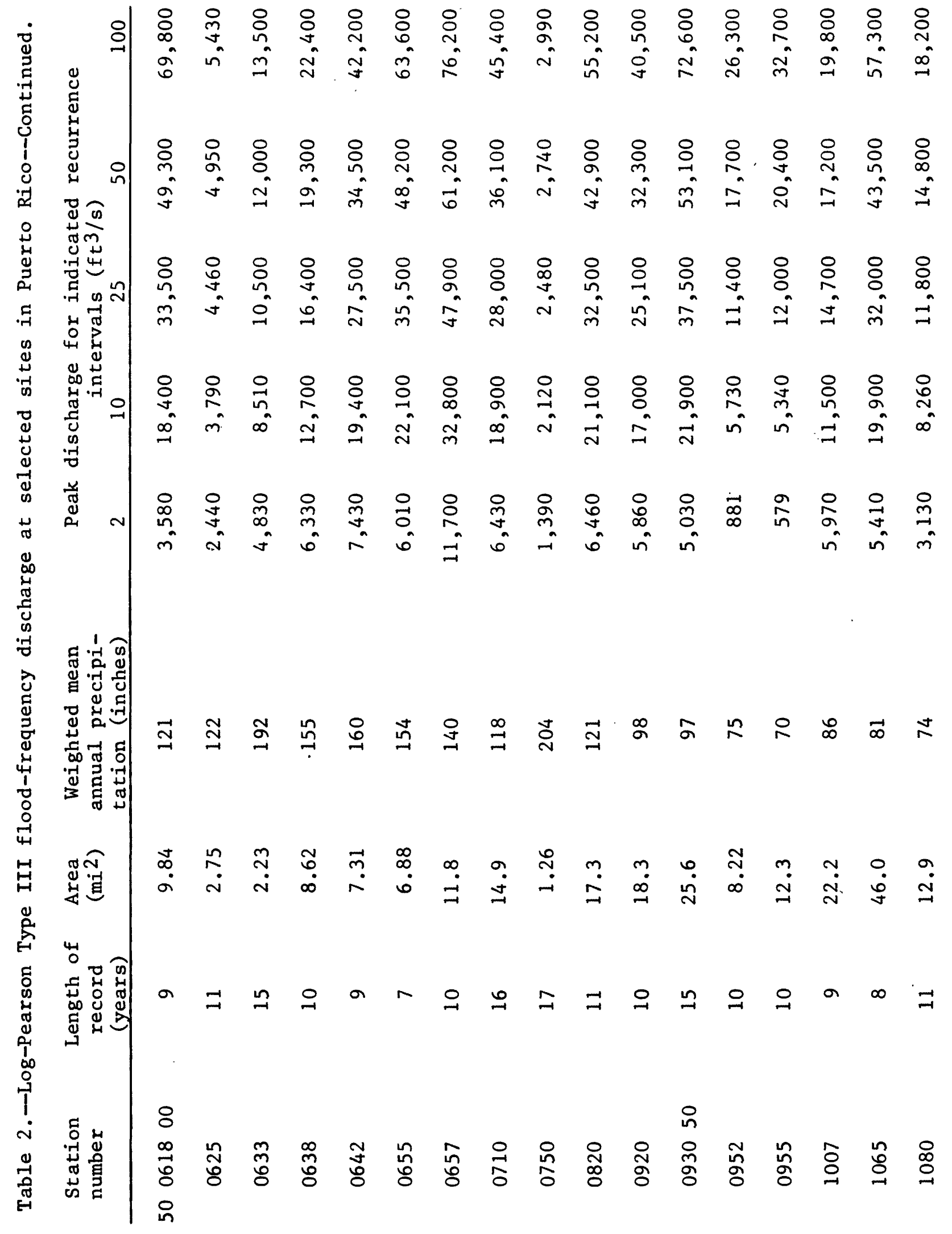




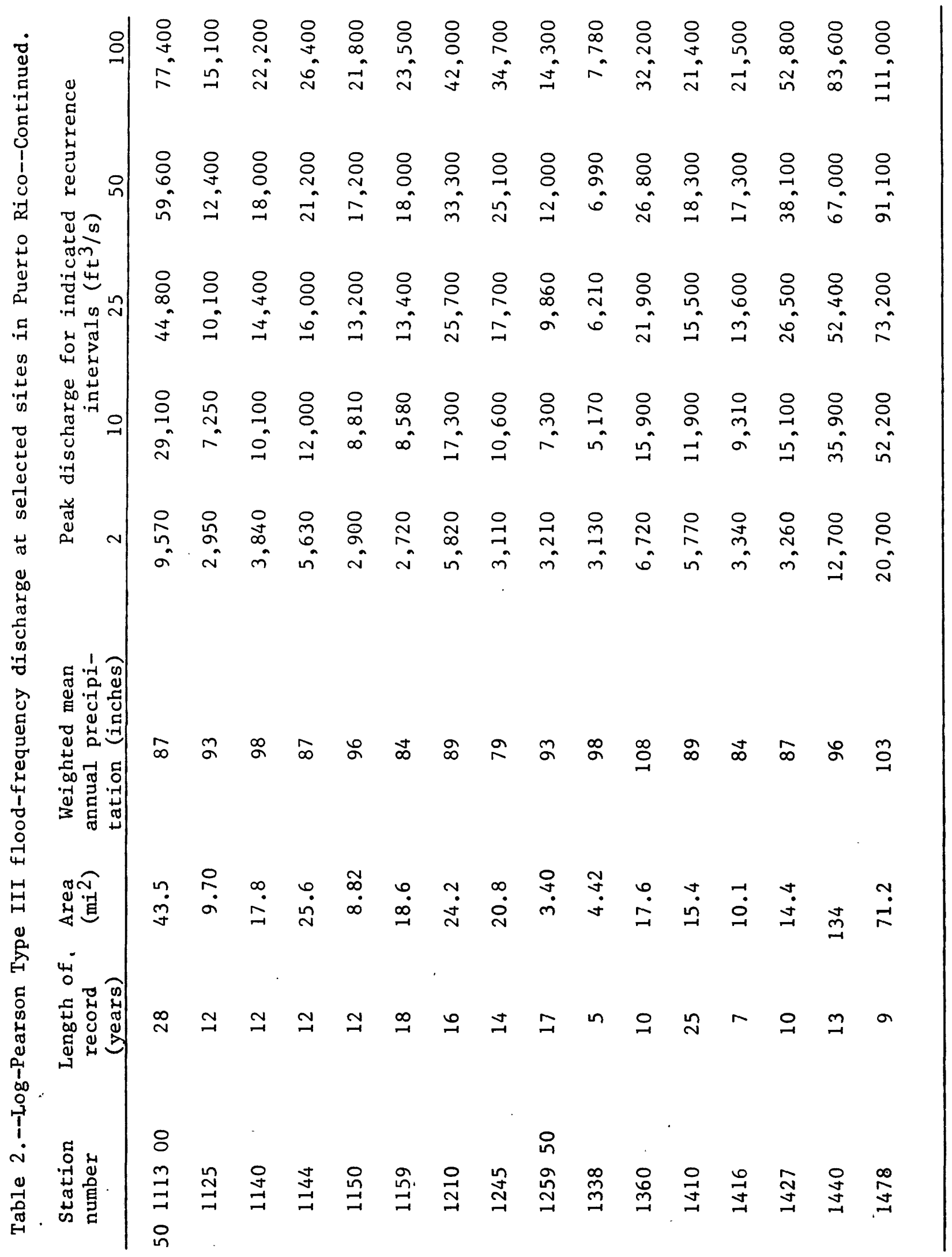




\section{MAXIMUM KNOWN FLOODS}

Maximum peak discharges known in Puerto Rico prior to January 1, 1976, are given in table 3. The list includes the maximum recorded peak discharge at some gaging stations used in the flood-frequency analysis, some sites where complete records for flood-frequency computations were not available, and historical flood data at sites investigated during flood-map surveys or bridge-site investigations.

Station numbers in the first column of table 3 correspond to those used to show the location of the sites in figure 1. Contributing drainage area is listed in the column following the stream name. Period of known floods indicates the calendar years for which flood data are available. Discharges shown represent unregulated flow, unless noted otherwise. The source of the peak discharge data is identified by footnoted symbols in the last column.

The maximum known peak discharges are plotted versus drainage area in figure 13 (data shown in table 3). For comparison, selected maximum known peak discharges in the United States were also plotted. An approximate upper limit curve was drawn roughly parallel to the plotted points and can be used as an estimator for the maximum floods in recent history in Puerto Rico.

\section{ASSESSMENT OF RESULTS}

\section{Adequacy of Flood Frequency Curves}

Considerable uncertainty in the definition of individual station floodfrequency curves exists because of the relatively short records available for analysis. The average length of annual peak record used in the final regression equations was 14.3 years.

\section{Adequacy of Basin Characteristics Used}

of all the basin characteristics used, only drainage area and mean annual precipitation proved to be significant in the final equations. An attempt was made to substitute the 24-hour 2-year recurrence interval and the 24-hour 25-year recurrence interval rainfall for the mean annual rainfall in the regression. One of the two proved to be significant when tested at the 95 percent confidence level, but in all cases the standard error of estimate was higher than when using mean annual precipitation.

The mean annual precipitation based on the U.S. Weather Bureau records from 1931 to 1960 should be fairly accurate. A more recent attempt to relate the variation of mean annual precipitation with elevation was made by Black and Veatch (1971) and seems to show the same pattern, but with more localized detail. Possibly the mean annual rainfall map may be modified upon further study. 
Table 3.--Maximum known floods in Puerto Rico prior to January 1, 1976.

Station number

50007000

0271

0350

0410

0440

0457

0460

0480

0530

0540

0550

0560

0570

0590

0610

0647
Station name

Quebrada de los Cedros near Isabela

Río Grande de Arecibo at Dos Bocas Dam

Río Grande de Manatí at Ciales

Río de la Plata near Cayey

Río de la Plata at Comerío Dam

Río Lajas at Toa Alta

Río de la Plata at Toa Alta

Río de Bayamón at Bayamón

Río Turabo at Hwy 765 near La Plaza

Quebrada de las Quebradillas near Caguas

Río Grande de Loíza at Caguas

Río Valenciano near Las Piedras

Río Gurabo at Gurabo

Río Grande de Loíza at Lago Loíza

Río Grande de Loíza at. Carolina

Quebrada Boneta at Río Grande
Latitude

Longitude

Drainage area $\left(m i^{2}\right)$

$18^{\circ} 30^{\prime} 46^{\prime \prime} \quad 67^{\circ} .05^{\prime} 47^{\prime \prime}$

$18^{\circ} 20^{\prime} 16^{\prime \prime}$

$66^{\circ} 40^{\prime} 05^{\prime \prime}$

169

$18^{\circ} 19^{\prime} 26^{\prime \prime} \quad 66^{\circ} 27^{\prime} 36^{\prime \prime}$

134

$18^{\circ} 08^{\prime} 24^{\prime \prime} \quad 66^{\circ} 09^{\prime} 49^{\prime \prime}$

42.2

$18^{\circ} 15^{\prime} 49^{\prime \prime}$

$66^{\circ} 12^{\prime} 24^{\prime \prime}$

140

$18^{\circ} 23^{\prime} 28^{\prime \prime}$

$66^{\circ} 15^{\prime} 28^{\prime \prime}$

8.4

$18^{\circ} 23^{\prime} 50^{\prime \prime}$

$66^{\circ} 15^{\prime} 17^{\prime \prime}$

208

$18^{\circ} 23^{\prime} 53^{\prime \prime} \quad 66^{\circ} 08^{\prime} 25^{\prime \prime}$

71.9

$18^{\circ} 09^{\prime} 27^{\prime \prime}$

$66^{\circ} 02^{\prime} 24^{\prime \prime}$

6.82

$18^{\circ} 11^{\prime} 36^{\prime \prime}$

$66^{\circ} 03^{\prime} 48^{\prime \prime}$

6.25

$18^{\circ} 14^{\prime} 35^{\prime \prime}$

$66^{\circ} 00^{\prime} 35^{\prime \prime}$

89.8

$18^{\circ} 10^{\prime} 37^{\prime \prime}$

$65^{\circ} 54^{\prime} 21^{\prime \prime}$

6.85

$18^{\circ} 15^{\prime} 30^{\prime \prime} \quad .65^{\circ} 58^{\prime} 05^{\prime \prime}$

60.2

$18^{\circ} 19^{\prime} 49^{\prime \prime} \quad 66^{\circ} 01^{\prime} 00^{\prime \prime}$

207

$18^{\circ} 22^{\prime} 39^{\prime \prime}$

$65^{\circ} 57^{\prime} 08^{\prime \prime}$

243

$18^{\circ} 22^{\prime} 42^{\prime \prime}$

$65^{\circ} 49^{\prime} 48^{\prime \prime}$ 
Table 3.--Maximum known floods in Puerto Rico prior to January 1, 1976--Continued

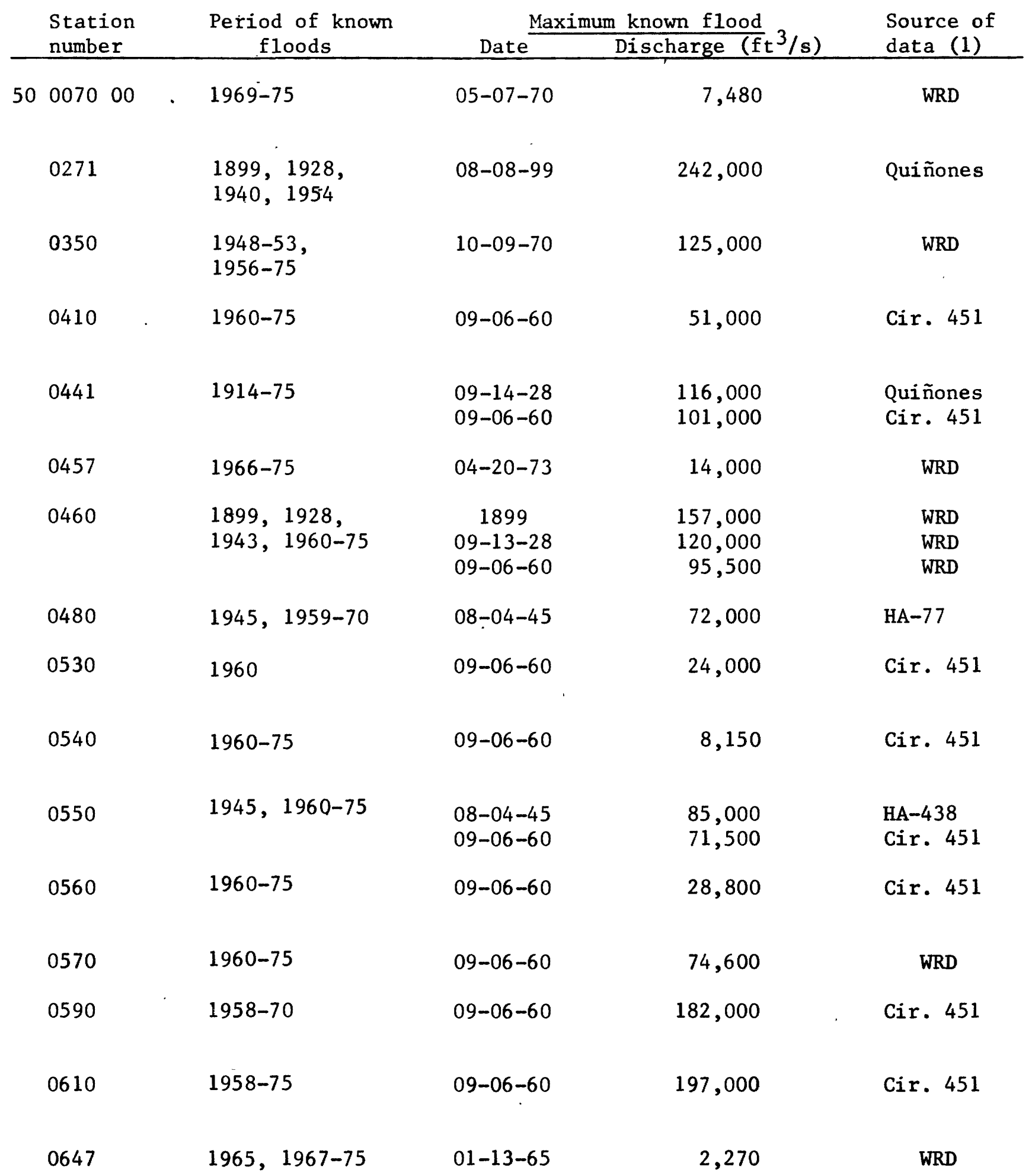


Table 3.--Maximum known floods in Puerto Rico prior to January 1, 1976--Continued

\begin{tabular}{|c|c|c|c|c|}
\hline $\begin{array}{l}\text { Station } \\
\text { number }\end{array}$ & Station name & Latitude & Longitude & $\begin{array}{c}\text { Drainage } \\
\text { area }\left(\mathrm{mi}^{2}\right)\end{array}$ \\
\hline $50 \quad 081000$ & $\begin{array}{l}\text { Río Humacao at } \\
\text { Las Piedras }\end{array}$ & $18^{\circ} 10^{\prime} 27^{\prime \prime}$ & $65^{\circ} 52^{\prime} 11^{\prime \prime}$ & 6.65 \\
\hline 0818 & $\begin{array}{l}\text { Río Humacao at Hwy } 30 \\
\text { at Humacao }\end{array}$ & $18^{\circ} 09^{\prime} 45^{\prime \prime}$ & $65^{\circ} 50^{\prime} 23^{\prime \prime}$ & 10.0 \\
\hline 091690 & $\begin{array}{l}\text { Río de Apeadero at } \\
\text { Patillas }\end{array}$ & $17^{\circ} 59^{\prime} 45^{\prime \prime}$ & $66^{\circ} 00^{\prime} 30^{\prime \prime}$ & 4.62 \\
\hline 1113 & $\begin{array}{l}\text { Río Jacaguas at Lago } \\
\text { Guayabal }\end{array}$ & $18^{\circ} 05^{\prime} 16^{\prime \prime}$ & $66^{\circ} 30^{\prime} 08^{\prime \prime}$ & 43.5 \\
\hline 1144 & Río Bucaná near Ponce & $18^{\circ} 02^{\prime} 18^{\prime \prime}$ & $66^{\circ} 35^{\prime} 12^{\prime \prime}$ & 25.6 \\
\hline 1159 & $\begin{array}{l}\text { Río Portugués at } \\
\text { Hwy } 14 \text { at Ponce }\end{array}$ & $18^{\circ} 01^{\prime} 09^{\prime \prime}$ & $66^{\circ} 36^{\prime} 26^{\prime \prime}$ & 18.6 \\
\hline 1245 & $\begin{array}{l}\text { Río Guayanilla at } \\
\text { Guayanilla }\end{array}$ & $18^{\circ} 02^{\prime} 01^{\prime \prime}$ & $66^{\circ} 47^{\prime} 57^{\prime \prime}$ & 20.8 \\
\hline 1280 & Río Yauco near Yauco & $17^{\circ} 59^{\prime} 19^{\prime \prime}$ & $66^{\circ} 49^{\prime} 55^{\prime \prime}$ & 45.5 \\
\hline 1360 & Río Rosario at Rosario & $18^{\circ} 10^{\prime} 24^{\prime \prime}$ & $67^{\circ} 04^{\prime} 27^{\prime \prime}$ & 17.6 \\
\hline 1380 & $\begin{array}{l}\text { Río Guanajibo near } \\
\text { Hormigueros }\end{array}$ & $18^{\circ} 08^{\prime} 29^{\prime \prime}$ & $67^{\circ} 08^{\prime} 46^{\prime \prime}$ & 120 \\
\hline 1390 & Río Yaguez at Mayaguez & $18^{\circ} 12^{\prime} 27^{\prime \prime}$ & $67^{\circ} 08^{\prime} 27^{\prime \prime}$ & 13.2 \\
\hline 1440 & $\begin{array}{l}\text { Río Grande de Añasco } \\
\text { near San Sebastiân }\end{array}$ & $18^{\circ} 17^{\prime} 00^{\prime \prime}$ & $67^{\circ} 03^{\prime} 02^{\prime \prime}$ & 134 \\
\hline 1478 & $\begin{array}{l}\text { Río Culebrinas at } \\
\text { Hwy } 404 \text { near Moca }\end{array}$ & $18^{\circ} 21^{\prime} 42^{\prime \prime}$ & $67^{\circ} 05^{\prime} 33^{\prime \prime}$ & 71.2 \\
\hline
\end{tabular}

(1) Source of data: WRD Water Resources Data for Puerto Rico, Part 1. Surface Water Records published by U.S. Geological Survey

Quiñones High intensity rainfall and major floods in Puerto Rico. Published in 1952.

Cir. 451 U.S. Geological Survey Circular 451, Floods of Sept. 6, 1960, in eastern Puerto Rico. 
Table 3.--Maximum known floods in Puerto Rico prior to January 1, 1976--Continued

\begin{tabular}{|c|c|c|c|c|}
\hline $\begin{array}{l}\text { Station } \\
\text { number }\end{array}$ & $\begin{array}{l}\text { Period of known } \\
\text { floods }\end{array}$ & Date & $\frac{n \text { known flood }}{\text { Discharge }\left(\mathrm{ft}^{3} / \mathrm{s}\right)}$ & $\begin{array}{l}\text { Source of } \\
\text { data (1) }\end{array}$ \\
\hline $50 \quad 0810 \quad 00$ & $1960-75$ & $09-06-60$ & 20,800 & Cir. 451 \\
\hline 0818 & $1960-75$ & $09-06-60$ & 27,600 & Cir. 451 \\
\hline 091690 & 1970 & $10-07-70$ & 14,000 & Bull. 12 \\
\hline 1113 & 1940 & $05-19-40$ & 78,000 & Quiñones \\
\hline 1144 & $\begin{array}{l}1899,1954, \\
1958,1961-72\end{array}$ & $08-08-99$ & 47,000 & HA-261 \\
\hline 1159 & $\begin{array}{l}1899,1954, \\
1958-75\end{array}$ & $08-08-99$ & 35,000 & HA-261 \\
\hline 1245 & $\begin{array}{l}1899,1961-72, \\
1974-75\end{array}$ & $08-08-99$ & 39,000 & $\mathrm{HA}-414$ \\
\hline 1280 & $1899-1975$ & $08-08-99$ & 42,000 & $\mathrm{HA}-414$ \\
\hline 1360 & $1960-68,1975$ & $09-16-75$ & 33,600 & WRD \\
\hline 1380 & $\begin{array}{l}1945,1952, \\
1954,1975\end{array}$ & $09-16-75$ & 128,000 & WRD \\
\hline 1390 & $1933-75$ & $03-03-33$ & 25,000 & HA-128 \\
\hline 1440 & $1963-75$ & $09-16-75$ & 140,000 & WRD \\
\hline 1478 & $1967-75$ & $09-16-75$ & 69,000 & WRD \\
\hline
\end{tabular}

(1) Source of data--Continued: Bull. 12 Water-resources Bulletin 12, flood of Oct. 5-10, 1970 in Puerto Rico.

HA- Hydrologic Investigations Atlas series published by the U.S. Geological Survey. See table 1 . 


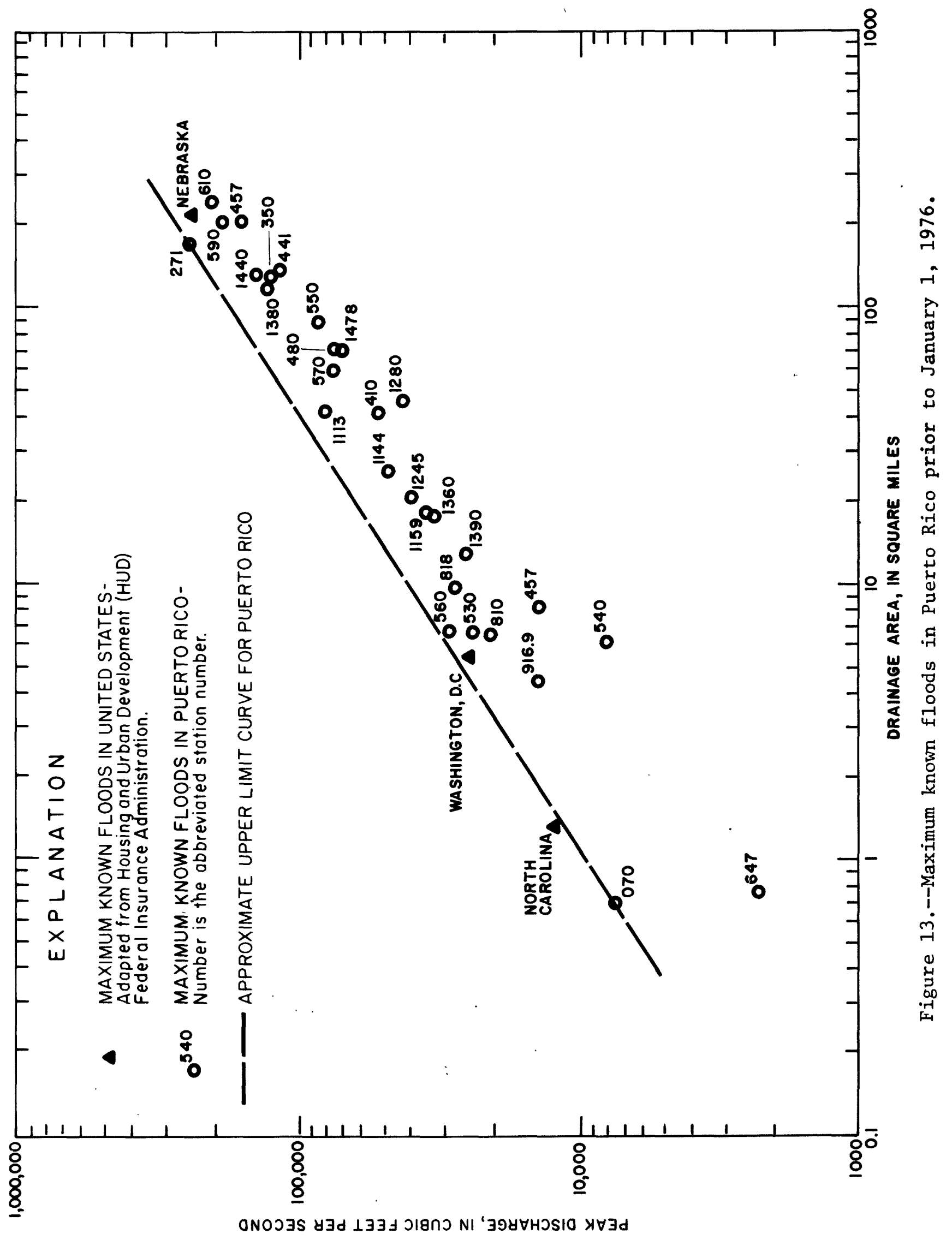


Other basin characteristics which would logically influence peak discharge rates did not prove statistically significant. Range in permeability was from 0.68 to $0.99 \mathrm{in} / \mathrm{hr}(17.3$ to $25.1 \mathrm{~mm} / \mathrm{hr})$ with the most common rates between 0.80 and $0.85 \mathrm{in} / \mathrm{hr}(20.3$ and $21.6 \mathrm{~mm} / \mathrm{hr})$. Average ground slope ranged between 29 and 50 percent with most values between 40 and 50 . Accuracy of average permeability and average ground slope varies throughout the island, depending on the method used by the U.S. Soil Conservation Service in mapping different areas.

\section{Recommendations for Future Investigations}

It is recommended that collection of annual flood peak data be continued especially at those sites where 10 or more years of record exist. Only after 20 or 30 stations have 25 years or more of annual peak record will the identification of regional flood-frequency characteristics be adequately defined.

\section{SELECTED REFERENCES}

Barnes, H. H., Jr., and Bogart, D. B., 1961, Floods of September 6, 1960, in eastern Puerto Rico: U.S. Geological Survey Circular 451, 13 p.

Beard, L. R., 1962, Statistical methods in hydrology: Sacramento, Calif., U.S. Army Corps of Engineers, 62 p.

Benson, M. A., 1960, Characteristics of frequency curves based on a theoretical 1,000-year record, in Dalrymple, Tate, Flood-frequency analysis: U.S. Geological Survey Water-Supp1y Páper 1553-A, p. 51-74.

1962, Factors influencing the occurrence of floods in a humid region of diverse terrain: U.S. Geological Survey Water-Supply Paper 1580-B, $64 \mathrm{p}$.

Black and Veatch Consulting Engineers, 1971, Water resources of Puerto Rico, Phase II, Surface water appraisa1, Vo1. 1: Puerto Rico Aqueduct and Sewer Authority, 298 p., 5 pl.

Briggs, R. P., and Akers, J. P., 1965, Hydrogeologic map of Puerto Rico and adjacent islands: U.S. Geological Survey Hydrologic Investigations Atlas HA-197.

Calvesbert, R. J., 1970, Climate of Puerto Rico and U.S. Virgin Islands: U.S. Environmental Data Service, Climatography of the United States no. 60-52.

Carter, R. W., and Benson, M. A.., 1969, Concepts for the design of streamflow data programs: U.S. Geological Survey open-file report, $20 \mathrm{p}$. 


\section{SELECTED REFERENCES--Continued}

Dalrymple, Tate, 1960, Flood-frequency analysis, in Manual of hydrology, part 3, flood-flow techniques: U.S. Geological Survey Water-Supply Paper 1543-A, 80 p.

Fields, F. K., 1971, Floods in the Añasco area, Puerto Rico: U.S. Geological Survey Hydrologic Investigations Atlas HA-375.

1971, Floods in the Yabucoa area, Puerto Rico: U.S. Geological Survey Hydrologic Investigations Atlas HA-382.

1971, Floods in the Guayanilla-Yauco area, Puerto Rico: U.S. Geological Survey Hydrologic Investigations Atlas HA-414.

1972, Floods at Caguas, Gurabo, Juncos, and San Lorenzo, Puerto Rico: U.S. Geological Survey Hydrologic Investigations Atlas HA-438.

Fields, F. K., and Jordan, D. G., 1972, Storm-wave swash along the north coast of Puerto Rico: U.S. Geological Survey Hydrologic Investigations Atlas $\mathrm{HA}-430$.

Giusti, E. V., and Bennett, G. D., 1976, Water-resources of the north coast limestone area, Puerto Rico: Water Resources Investigations no. 42-75, $42 \mathrm{p}$.

Gumbel, E. J., 1945, Floods estimated by the probability method: Engineering News Rec., June 14, p. 97-101.

Haire, W. J., 1971, Floods in Patillas-Maunabo area, Puerto Rico: U.S. Geological Survey Hydrologic Investigations Atlas HA-445.

1971, Floods in Guayama area, Puerto Rico: U.S. Geological Survey Hydrologic Investigations Atlas HA-446.

1971, Floods in Salinas area, Puerto Rico: U.S. Geological Survey Hydrologic Investigations Atlas HA-447.

1971, Floods in Santa Isabel area, Puerto Rico: U.S. Geological Survey Hydrologic Investigations Atlas HA-448.

1972, Floods in the Rio Guanajibo valley, southwestern Puerto Rico: U.S. Geological Survey Hydrologic Investigations Atlas HA-456.

1972, Floods in the Rio Piedras basin, San Juan, Puerto Rico: Puerto Rico Map series, no. 1.

1975, Floods in the Carolina-Río Grande area, northeastern Puerto Rico: U.S. Geological Survey Hydrologic Investigations Atlas HA-533. 


\section{SELECTED REFERENCES--Continued}

Haire, W. J., 1975, Floods in the Fajardo-Luquillo area, northeastern Puerto Rico: U.S. Geol. Survey Hydrologic Investigations Atlas HA-545.

1978, Floods in the Naguabo area, eastern Puerto Rico: U.S. Geological Survey Hydrologic Investigations Atlas HA-584.

Hardison, C. H., 1971, Prediction error of regression estimates of streamflow characteristics at ungaged sites, in Geological Survey Research 1971:

U.S. Geological Survey Professional Paper 750-C, p. C228-C236.

Hickenlooper, I. J., 1967, Floods at Barceloneta and Manatí, Puerto Rico: U.S. Geological Survey Hydrologic Investigations Atlas HA-262.

1968, Floods at Arecibo, Puerto Rico: U.S. Geological Survey Hydrologic Investigations Atlas HA-271.

1968, Floods in the Mayaguez area of Puerto Rico: U.S. Geological Survey Hydrologic Investigations Atlas HA-288.

1968, Floods in the area of Vega Alta and Vega Baja, Puerto Rico:

U.S. Geological Survey Hydrologic Investigations Atlas HA-289.

Hickenlooper, I. J., and López, M. A., Floods in the Ponce area, Puerto Rico: U.S. Geological Survey Hydrologic Investigations Atlas HA-261.

Johnson, K. G., 1972, Floods in the Aguadilla-Aguada area, northwestern Puerto Rico: U.S. Geological Survey Hydrologic Investigations Atlas HA-457.

1975, Floods in the Lajas Valley, Puerto Rico: U.S. Geological Survey Hydrologic Investigations Atlas HA-532.

Kipple, F. P., and others, 1968, Water records of Puerto Rico, 1958-63: San Juan, U.S. Geological Survey data report, 339 p.

Kirby, W. H., 1971, Flood estimation in the presence of outliers: Proceedings of symposium on statistical hydrology, U.S. Dept. Agriculture Miscellaneous Publications 1275.

Langbein, W. B., 1949, Annual floods and the partial-duration flood series: Am. Geophysical Union Trans., v. 30, p. 879-881.

López, M. A., 1962, Floods at Bayamón and Cataño, Puerto Rico: U.S. Geological Survey Hydrologic Investigations Atlas HA-77.

1964, Floods at Toa Alta, Toa Baja, and Dorado, Puerto Rico: U.S. Geological Survey Hydrologic Investigations Atlas HA-128. 


\section{SELECTED REFERENCES--Continued}

López, M. A., 1967, Floods at Humacao, Puerto Rico: U.S. Geological Survey Hydrologic Investigations Atlas HA-265.

López, M. A., and Fields, F. K., 1970, A proposed streamflow-data program for Puerto Rico: U.S. Geological Survey open-file report, 42 p.

Matalas, N. C., and Gilroy, E. J., 1968, Some comments on regionalization in hydrologic studies: Water Resources Research, v. 4, no. 6, p. 1361-1369.

Picó, Rafael, 1950, The geographic regions of Puerto Rico: Univ. Puerto Rico Press, $256 \mathrm{p}$.

Powe11, R. W., 1943, A simple method of estimating flood frequency: Civil Eng., v. 13, p. 105-106.

Puerto Rico Department of Natural Resources, 1974, Mapa de inventario de recursos naturales, culturales y ambientales: P.R. Dept. of Natural Resources, continuing map series.

Quiñones, M. A., 1952, High intensity rainfall and major floods in Puerto Rico: Mimeograph report, presented at Inter-Am. Convention, Am. Society Civil Eng., San Juan, Puerto Rico, Nov. 12-15, 1952.

Rickher, J. G., and others, 1970a, Water records of Puerto Rico, 1964-76, Volume 1--North and northeast slopes: San Juan, U.S. Geological Survey data report, v. 1, 265 p.

1970b, Water records of Puerto Rico, 1967, Volume 2--South and west slopes: San Juan, U.S. Geological Survey data report, v. 2, 303 p.

Riggs, H. C., 1968, Frequency curves: U.S. Geological Survey Techniques of Water Resources Investigations, book 4, chap. A2, 15 p.

U.S. Department of Commerce, 1961, Generalized estimates of probable maximum precipitation and rainfall frequency data for Puerto Rico and Virgin Islands: U.S. Weather Bureau Technical Paper no. 42, 94 p.

1965, Climatography of the United States no. 86-45. Decennial census of United States climate. Climatic summary of the United States supplement for 1951 through 1960, Puerto Rico and U.S. Virgin Islands:

Revised May 1969, Washington, D.C., 40 p.

U.S. Geological Survey, 1973, Water resources data for Puerto Rico, 1968, Part 1, Surface water records: U.S. Geological Survey data report, 87 p.

1973, Water resources data for Puerto Rico, 1969, Part 1, Surface water records: U.S. Geological Survey data report, 89 p. 


\section{SELECTED REFERENCES--Continued}

U.S. Geological Survey, 1973, Water resources data for Puerto Rico, 1970, Part 1, Surface water records: U.S. Geological Survey data report, 90 p.

1973, Water resources data for Puerto Rico, 1971, Part 1, Surface water records: U.S. Ceological Survey data report, 72 .

1974, Water resources data for Puerto Rico, 1972, Part 1, Surface water records: U.S. Geological Survey data report, $70 \mathrm{p}$.

1975, Water resources data for Puerto Rico, 1973, Part 1, Surface water records: U.S. Geological Survey data report, 69 p.

1977, Water resources data for Puerto Rico, 1974, Part 1, Surface water records: U.S. Geological Survey data report, 66 p.

U.S. Water Resources Council, 1967, A uniform technique for determining flood flow frequency: Bulletin no. 15 of the Hydrology Committee, $15 \mathrm{~F}$.

1977, Guidelines for determining flood flow frequency: Bulletin no. 17 of the Hydrology Committee, 163 p., 1 p1. 


\section{SUPPLEMENTARY DATA}

Table of annual maximum discharge records at gaging stations. 


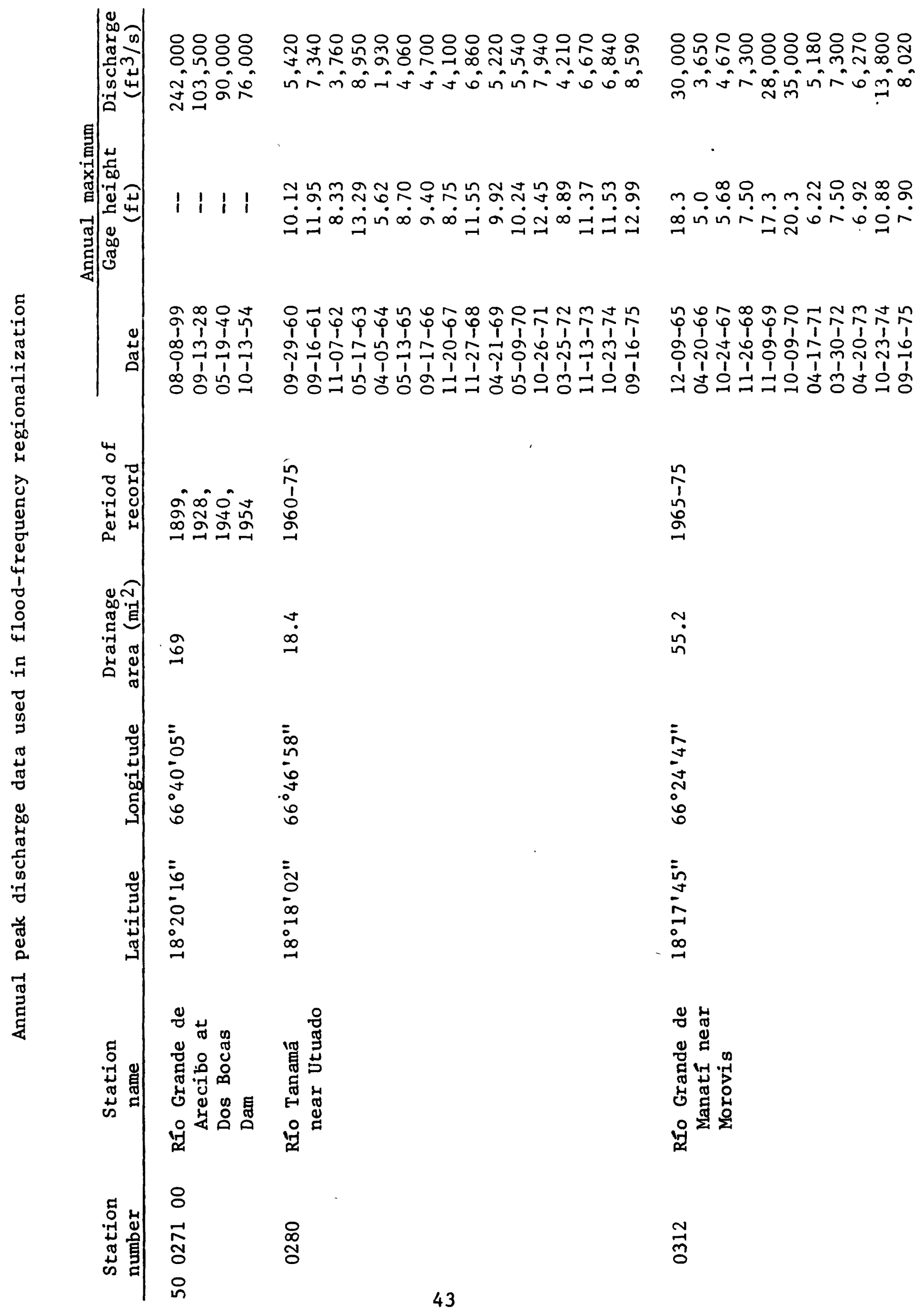




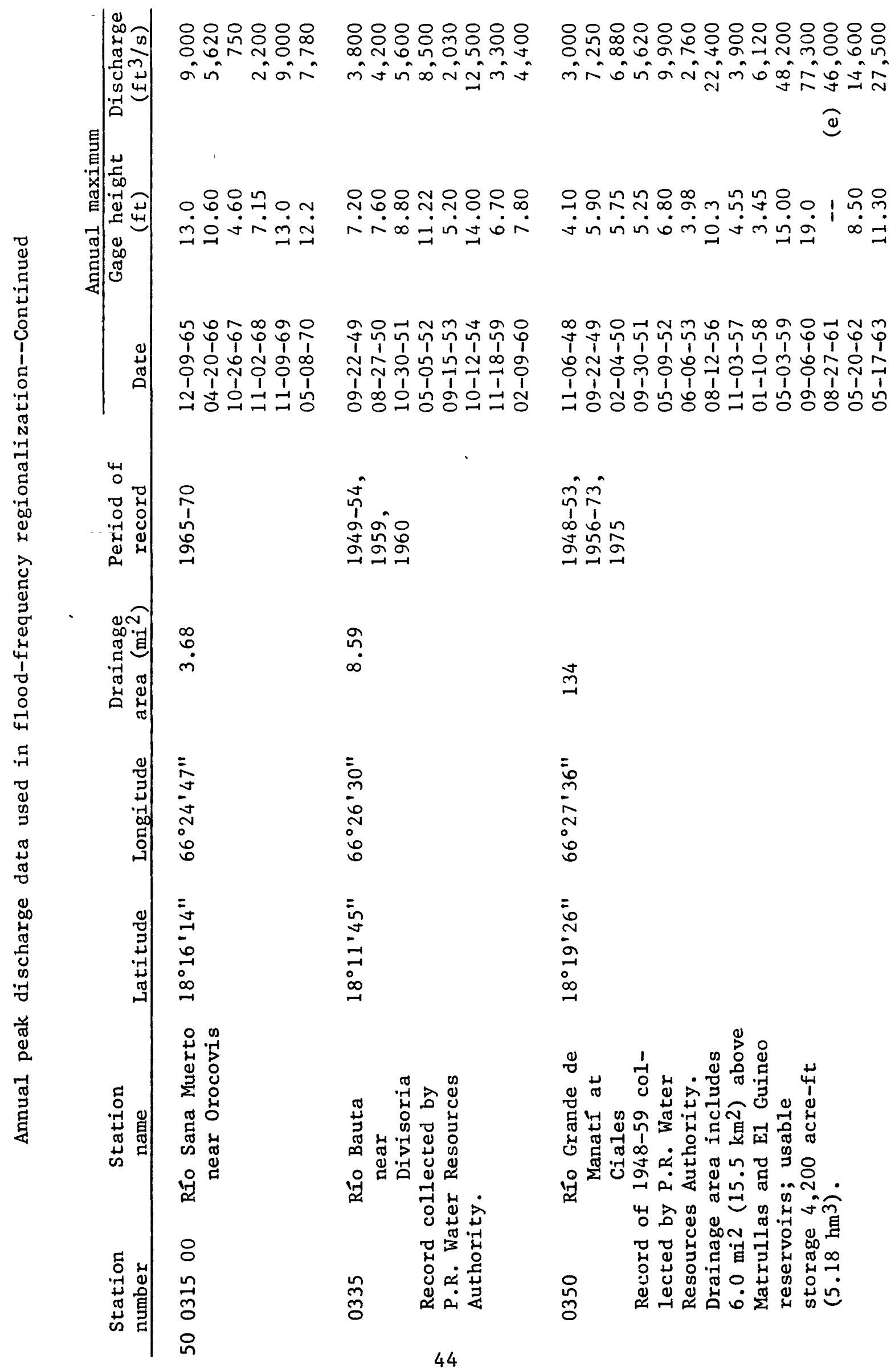




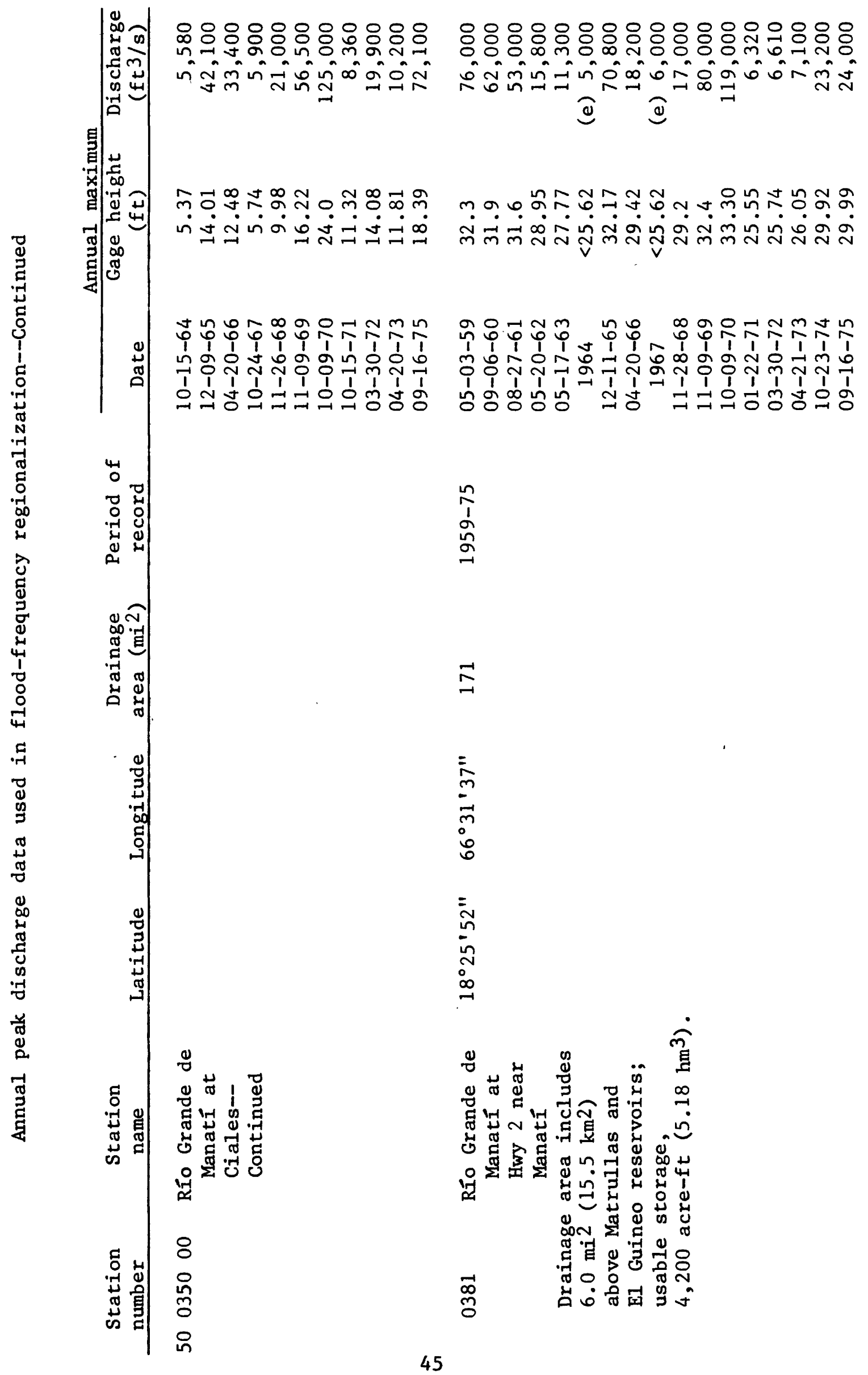




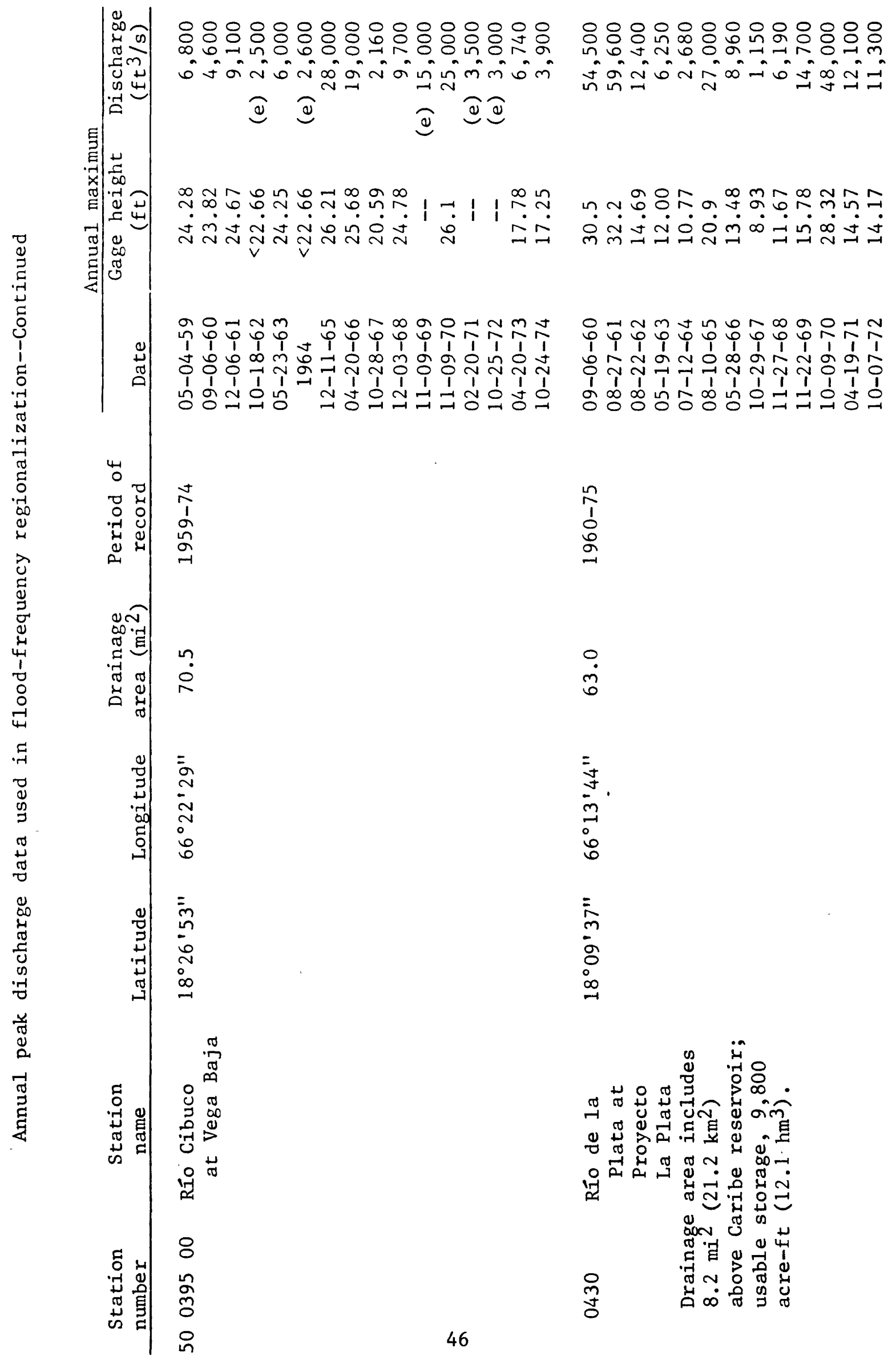




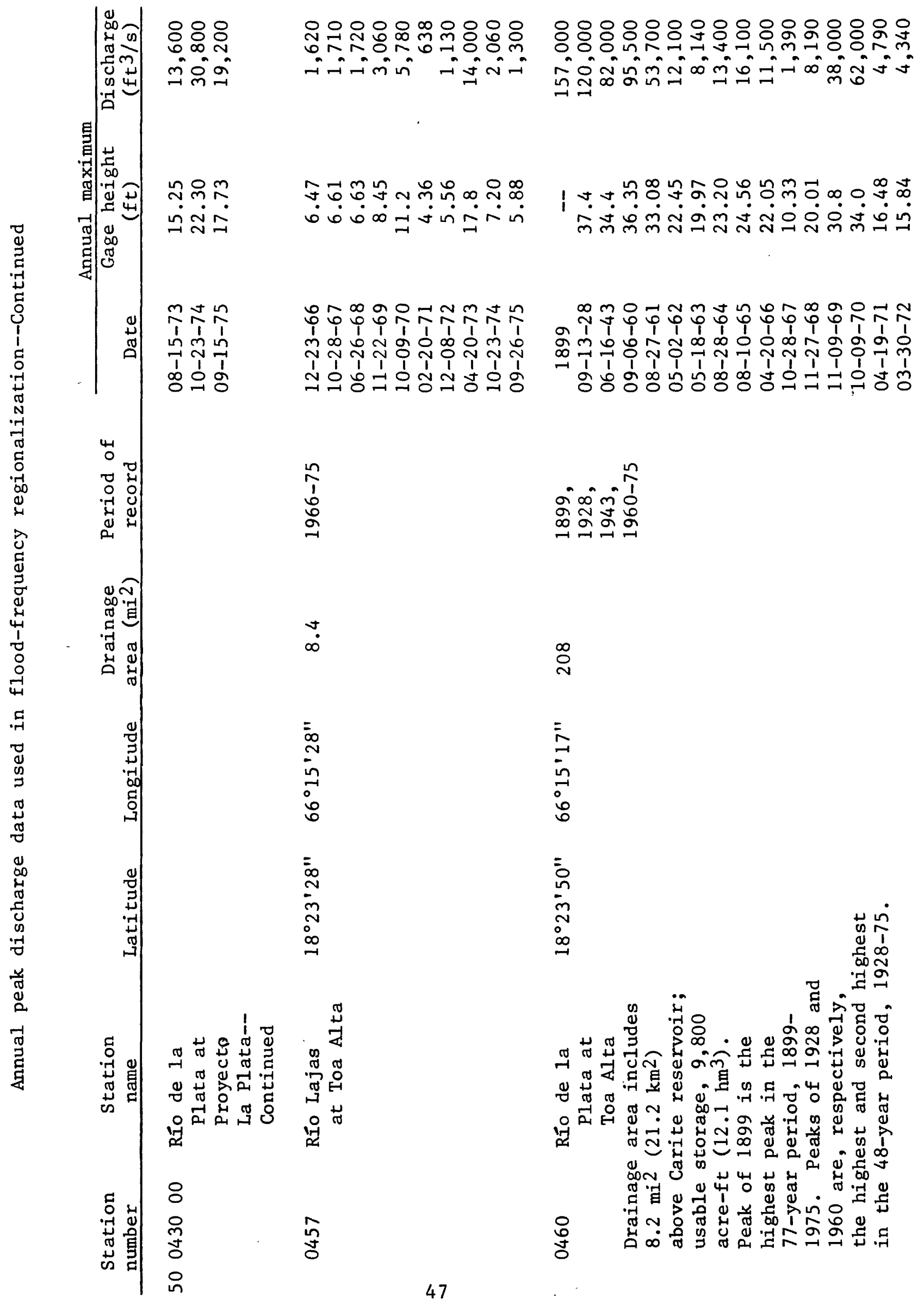




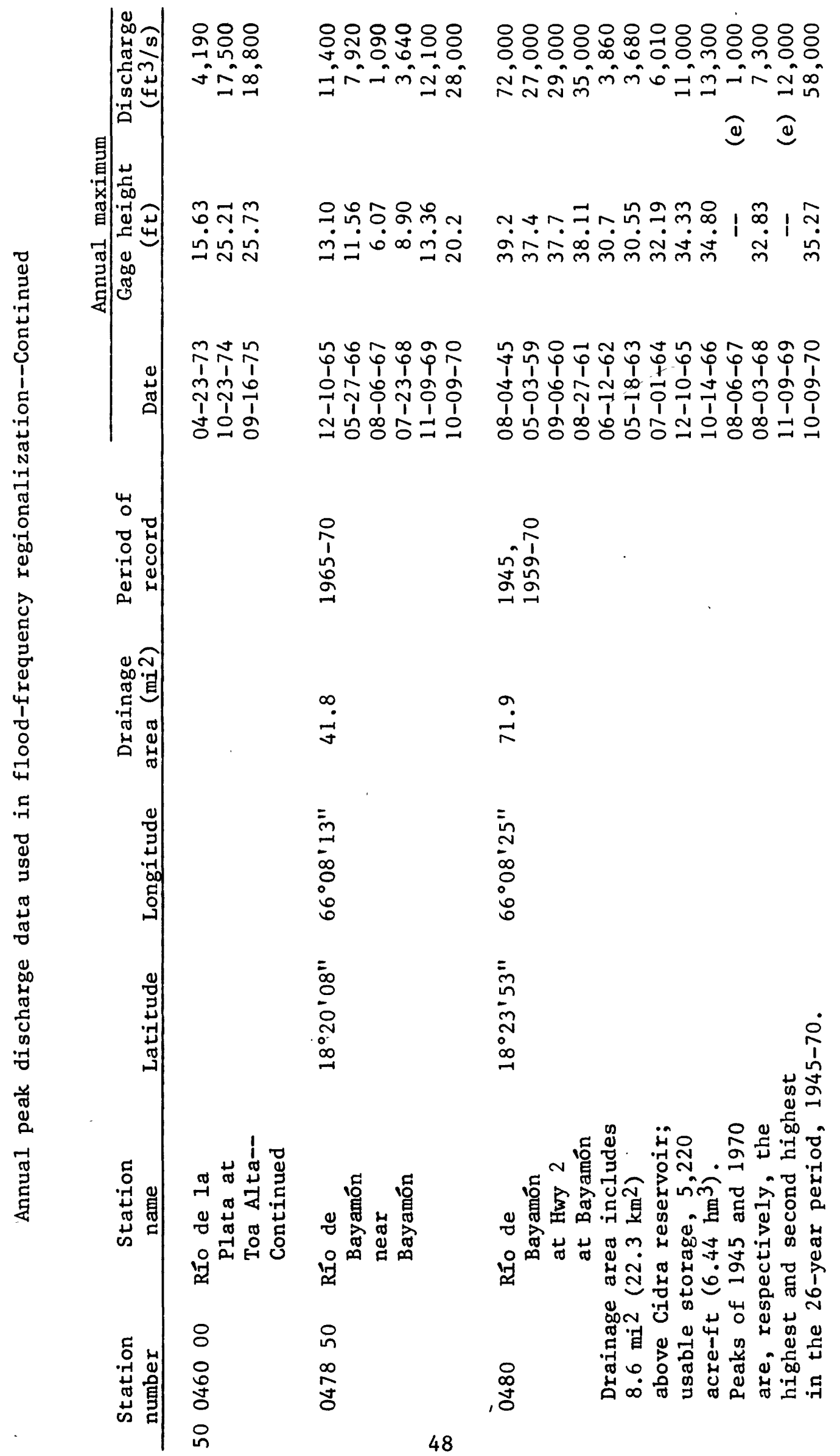




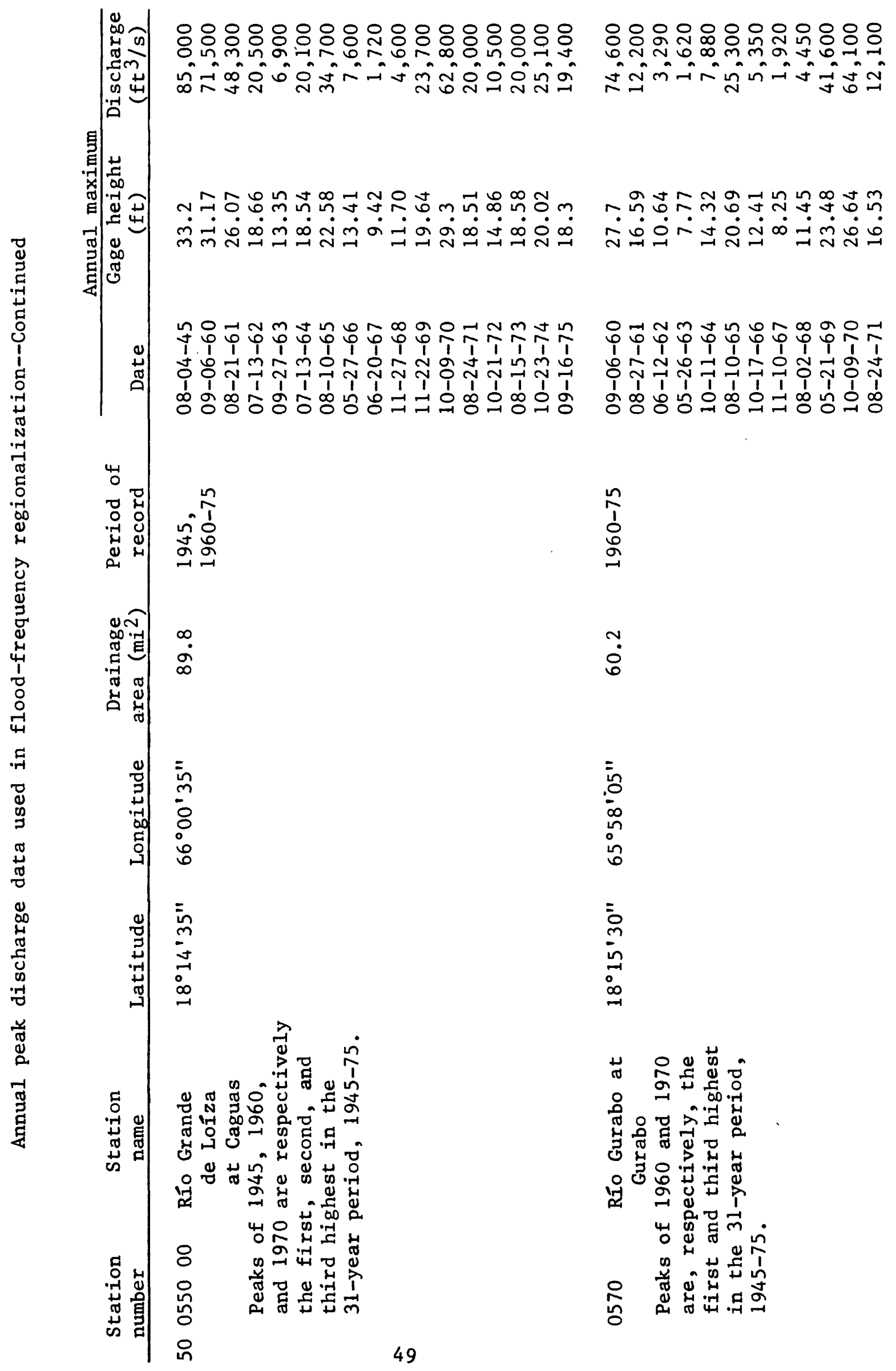




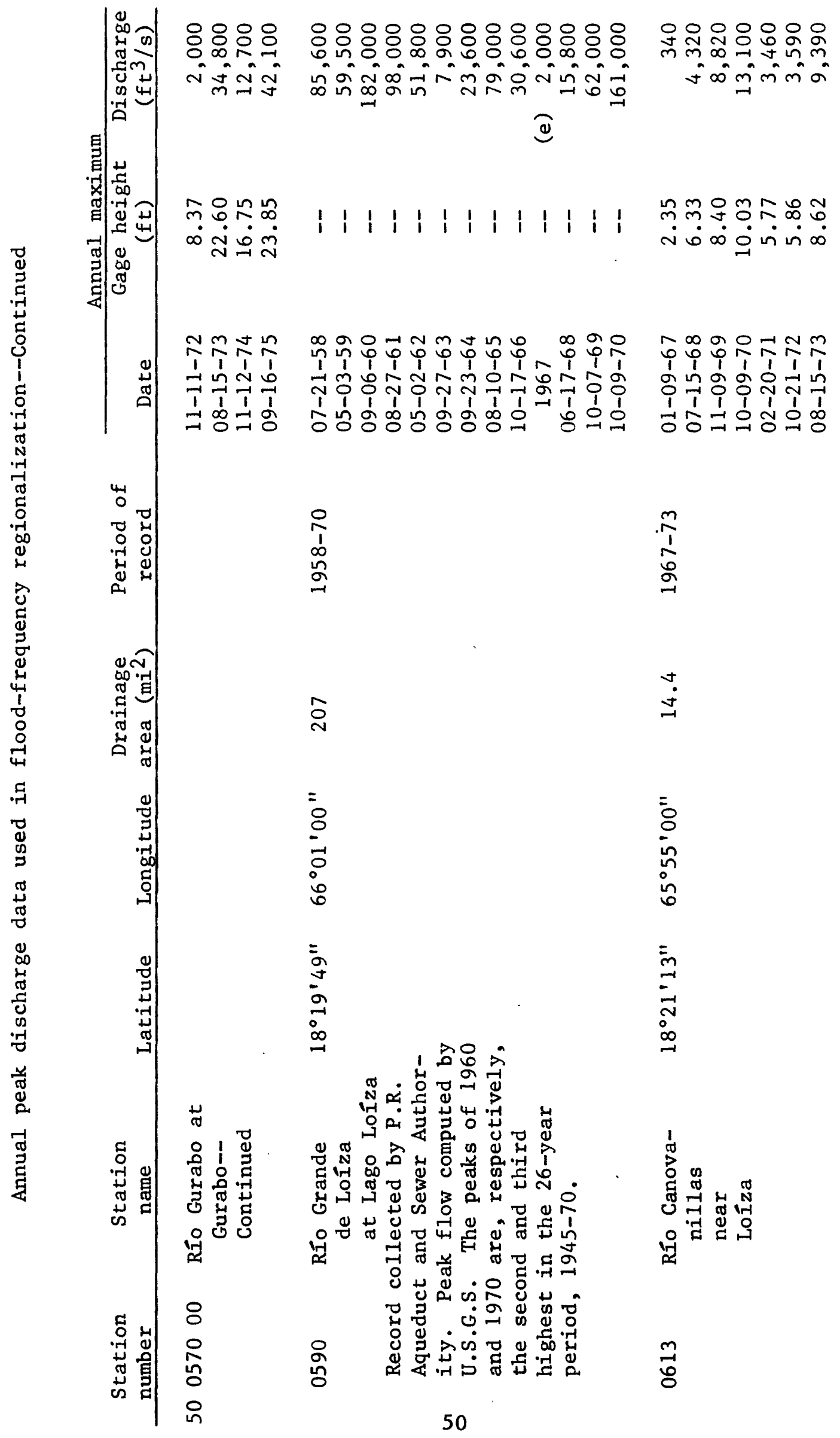




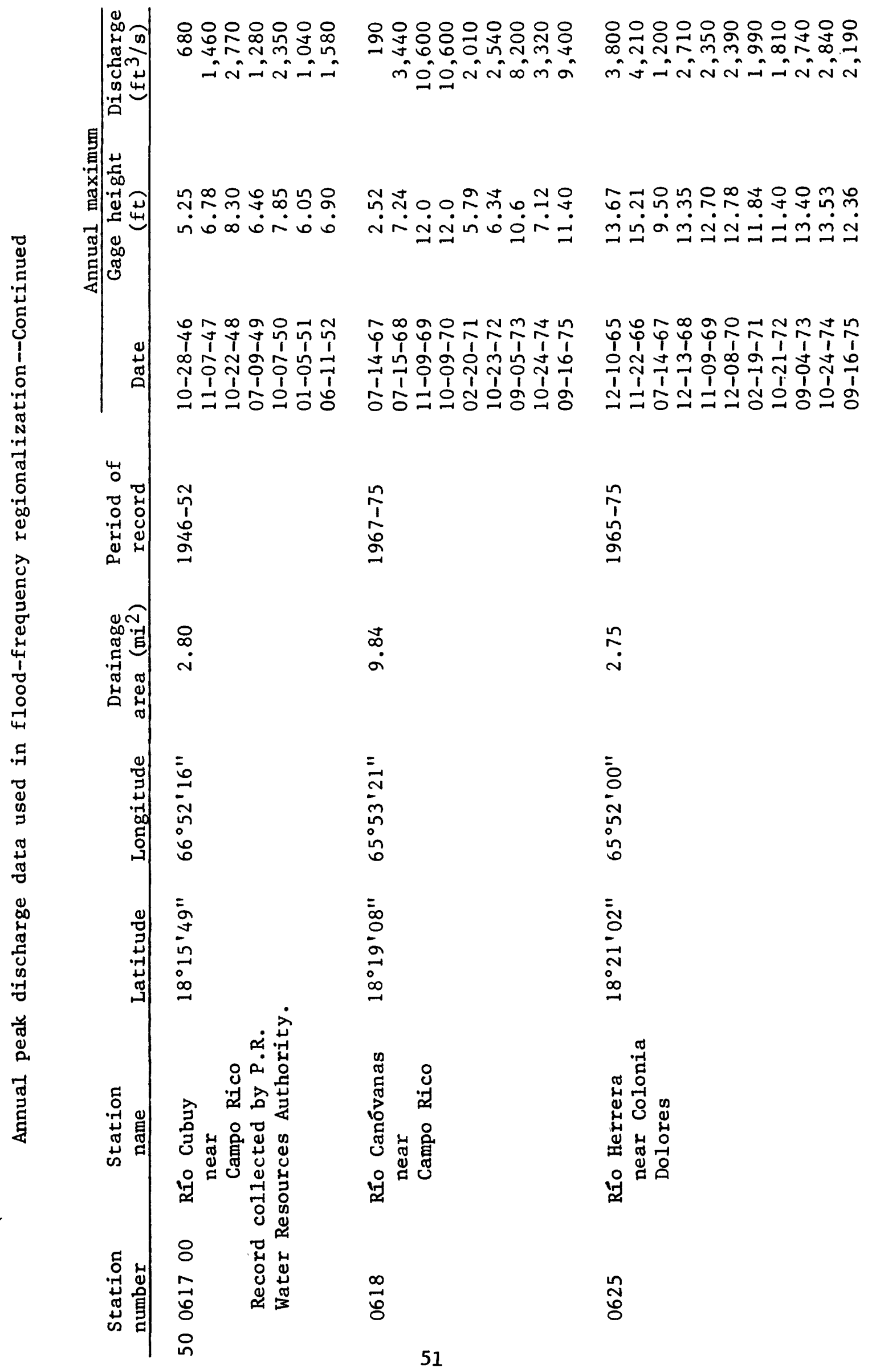




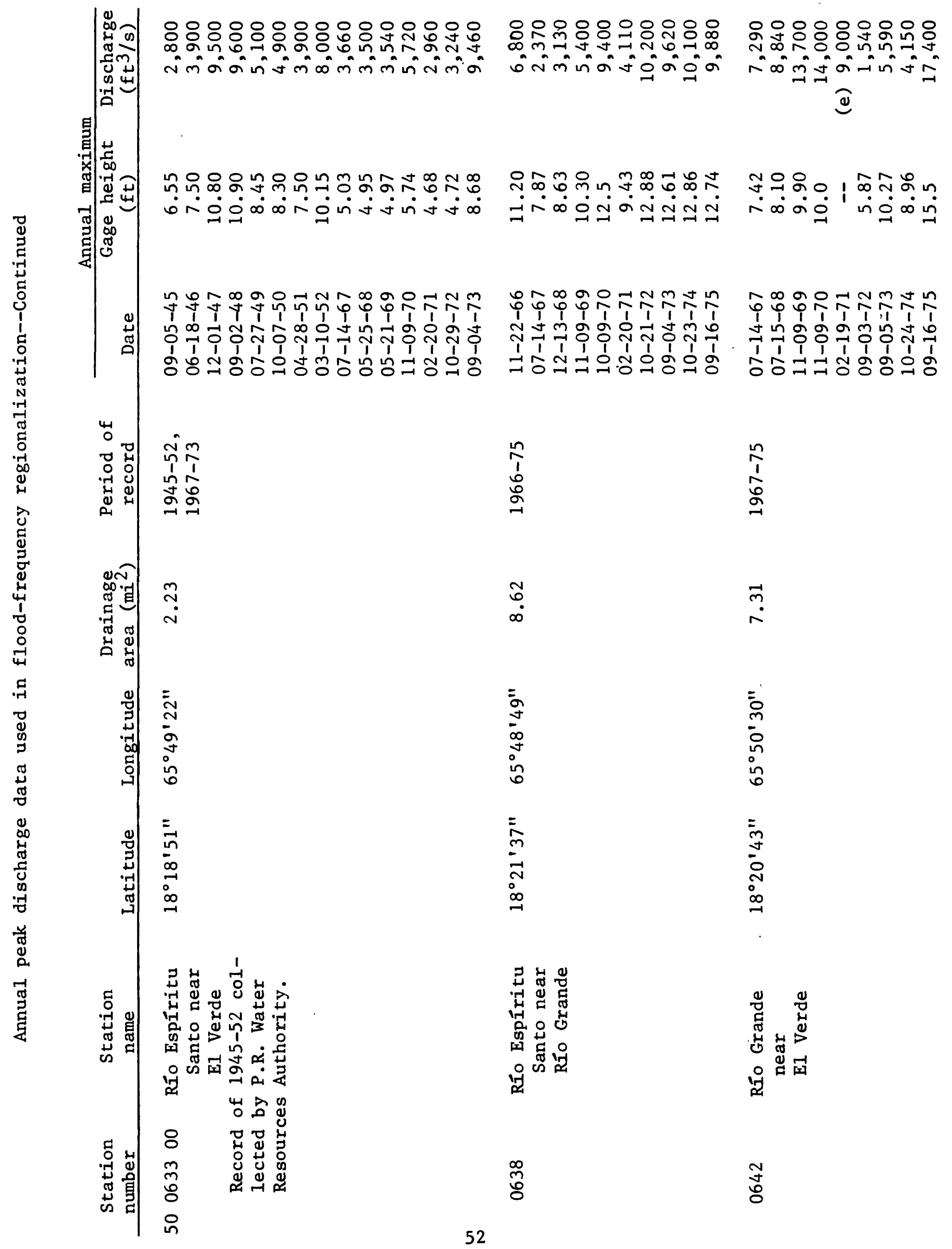




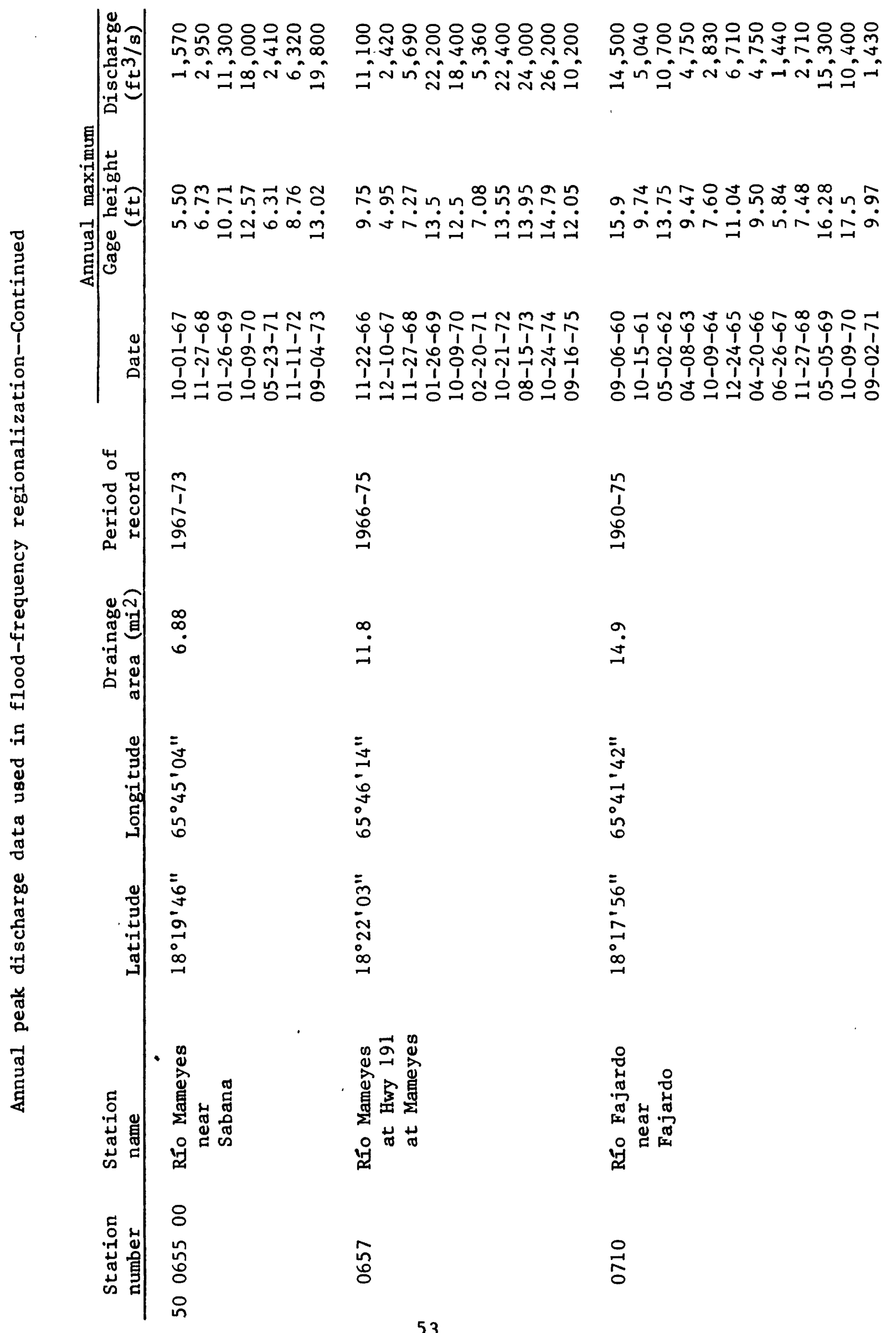




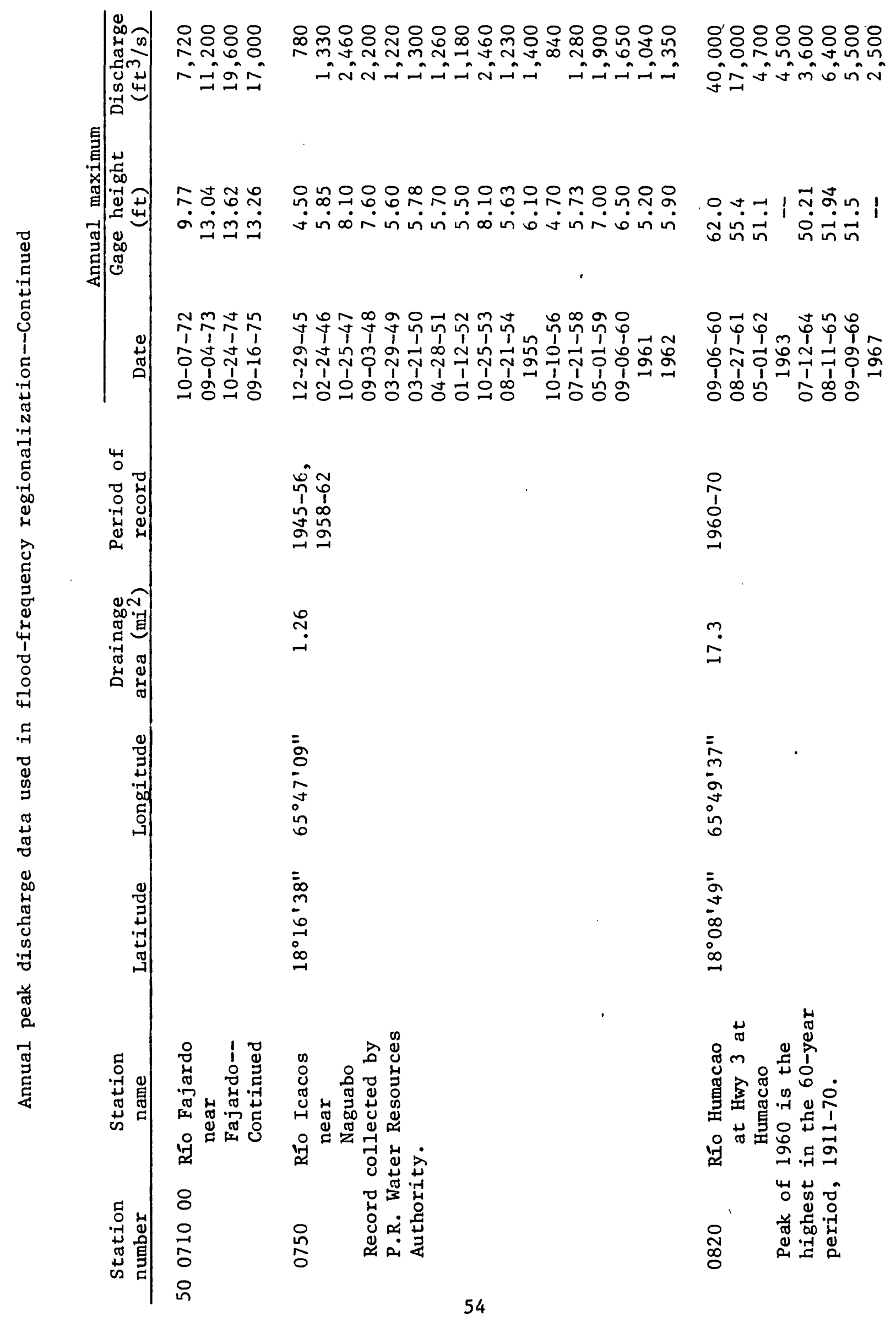




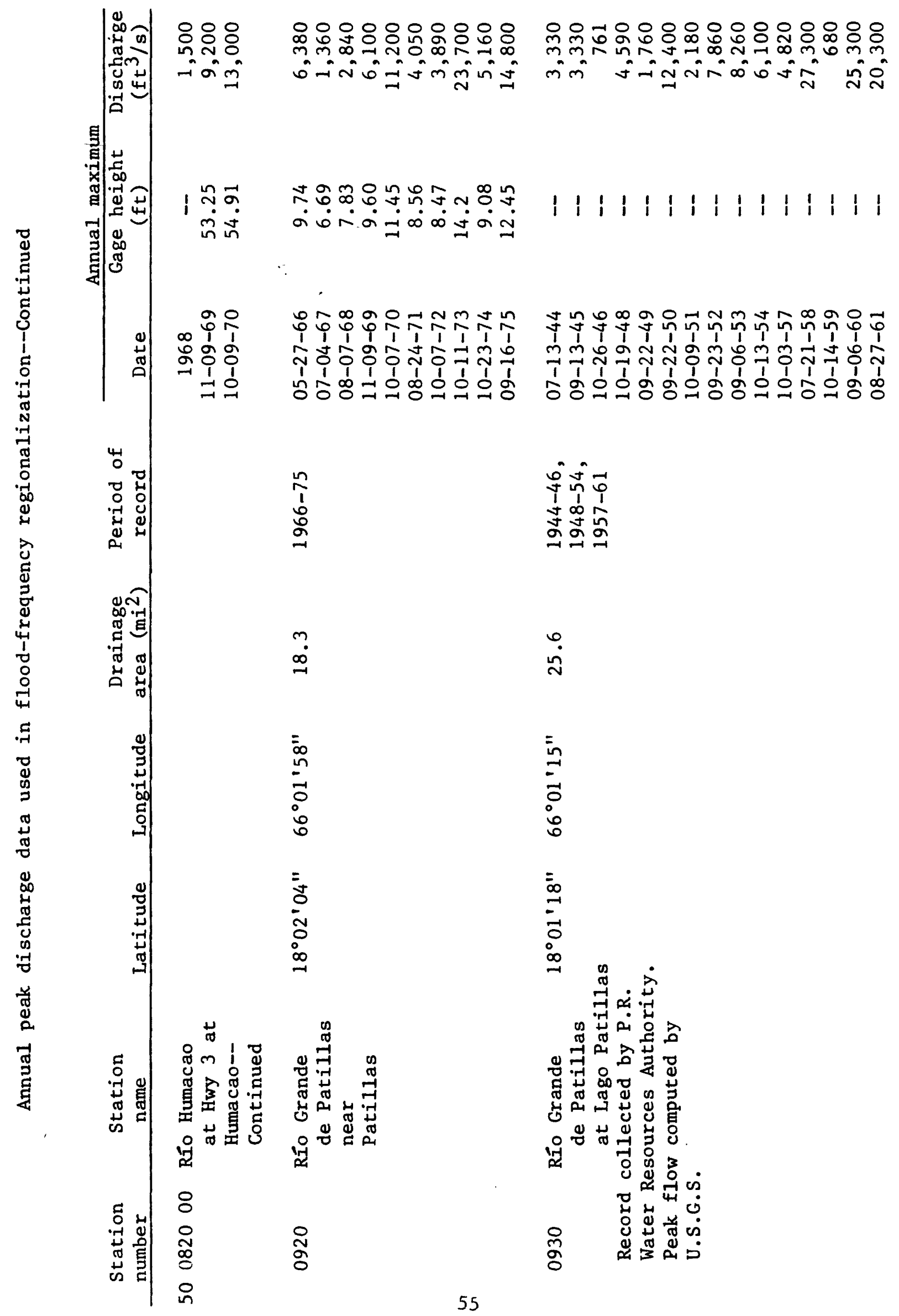




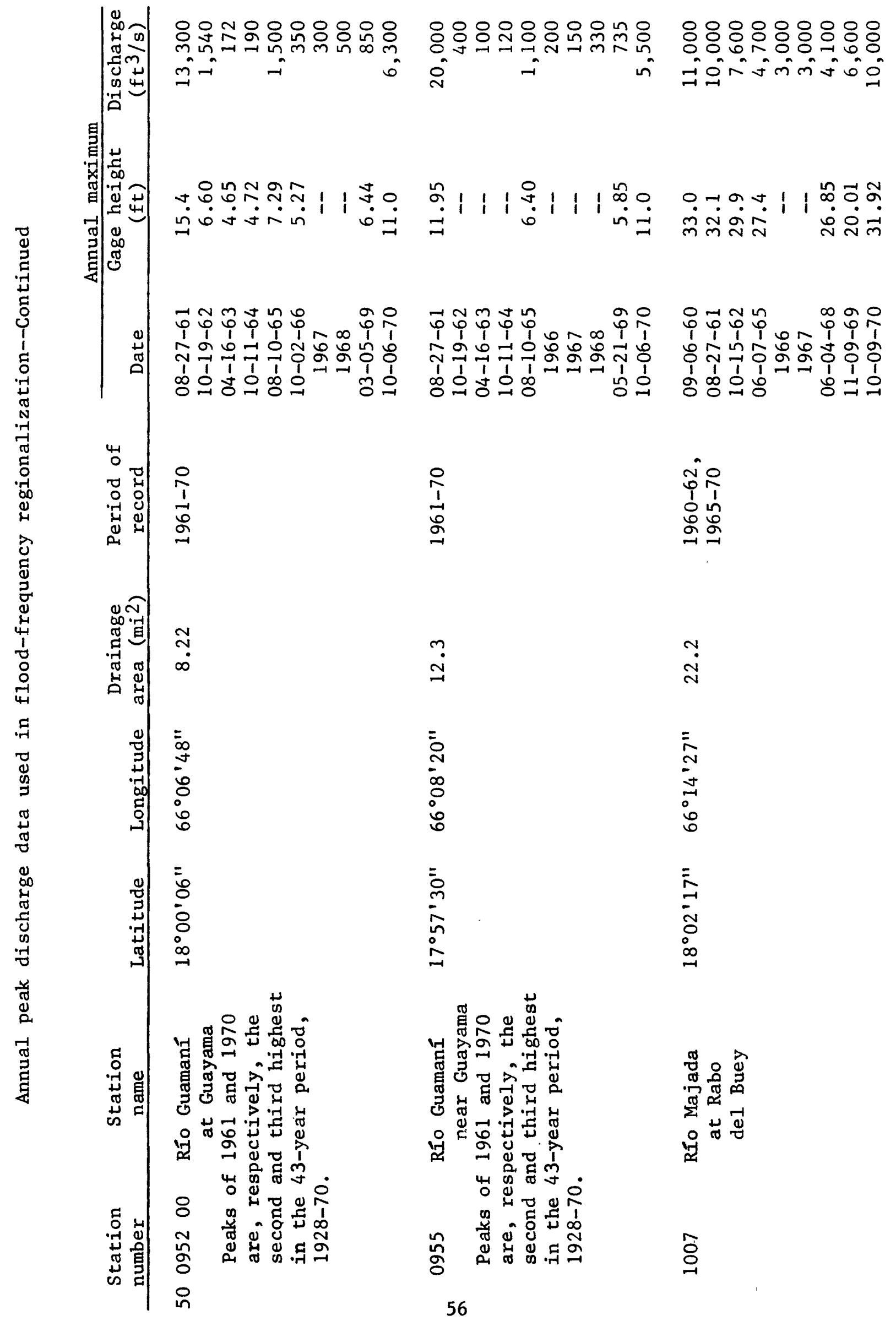




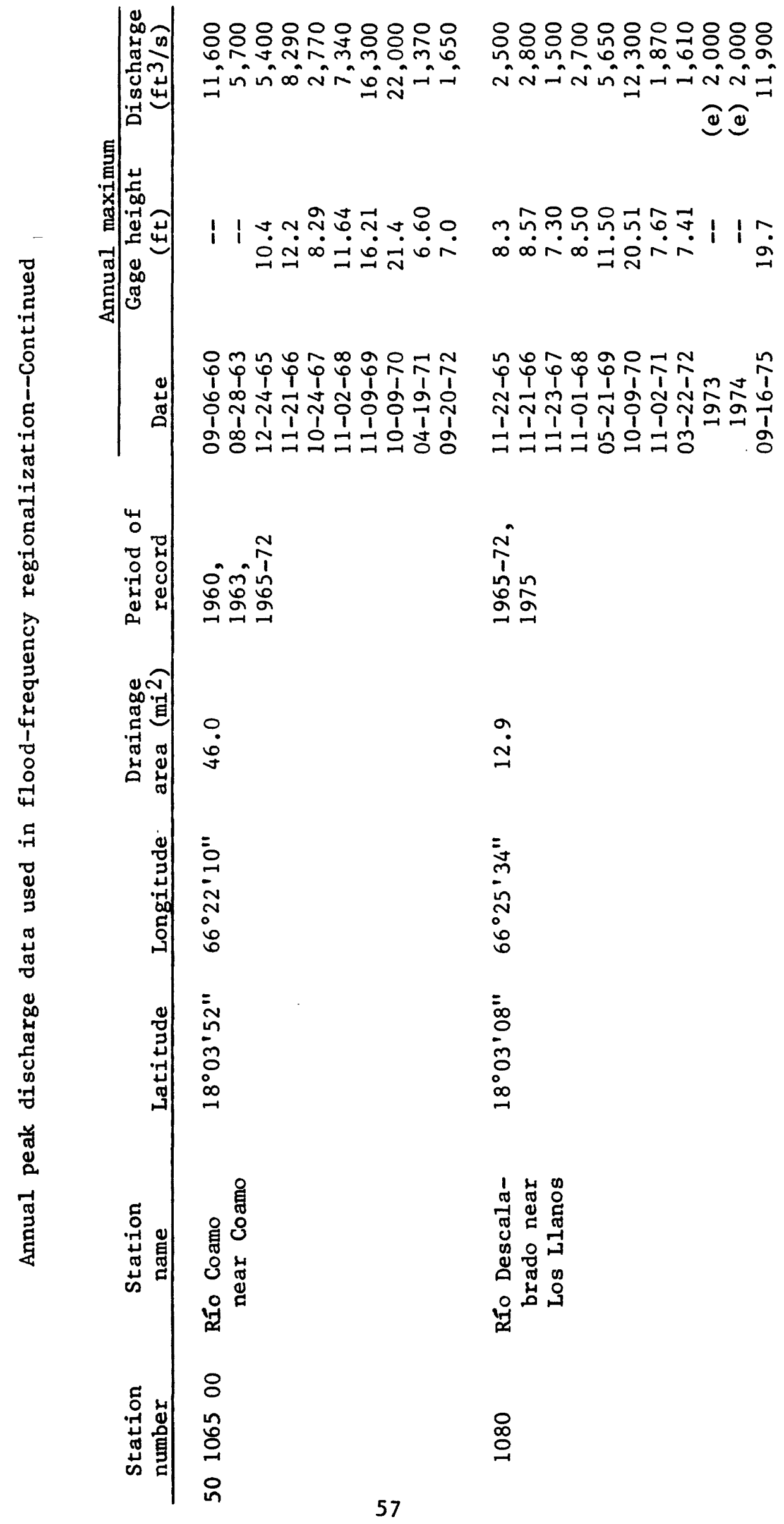




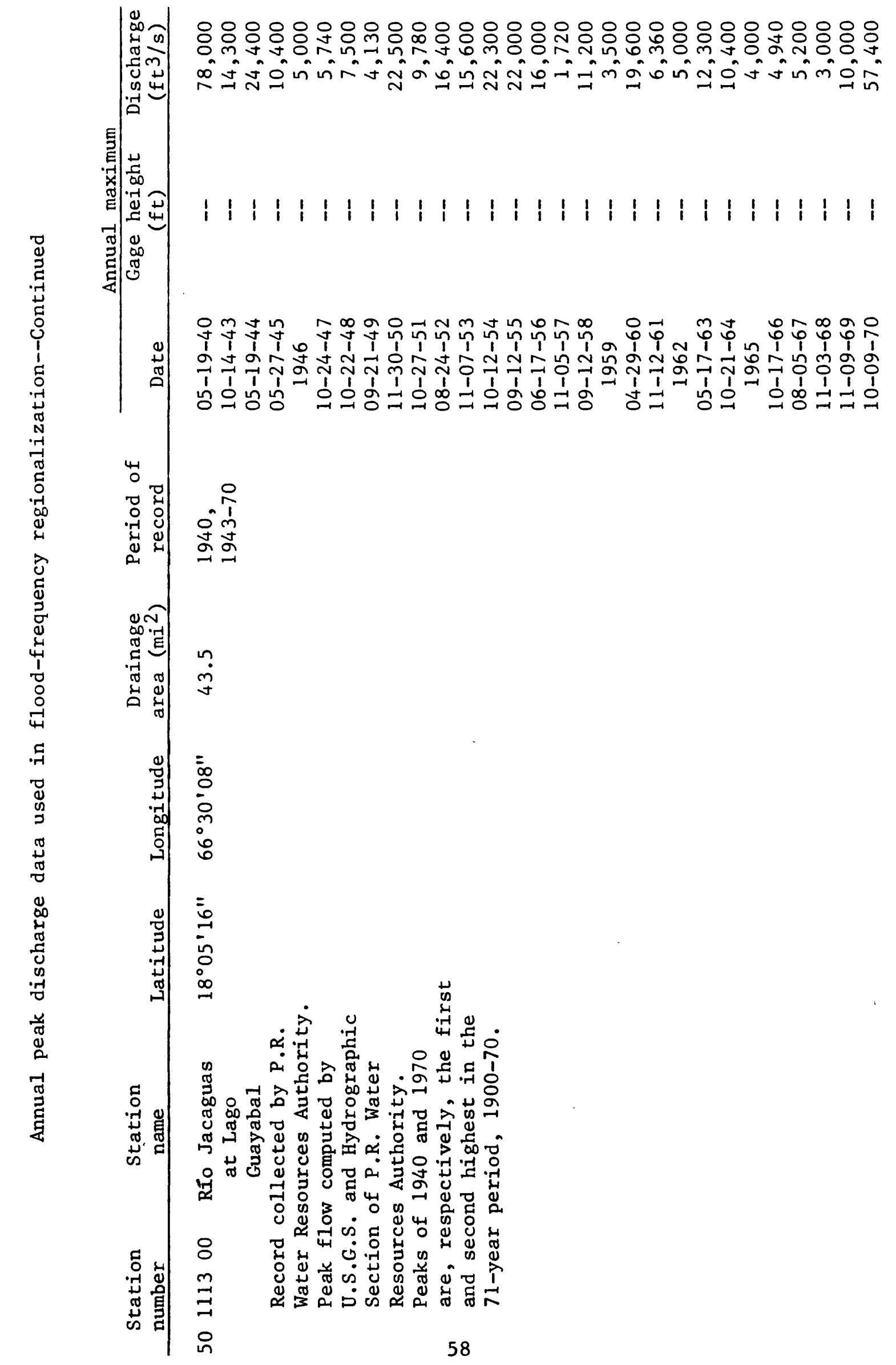




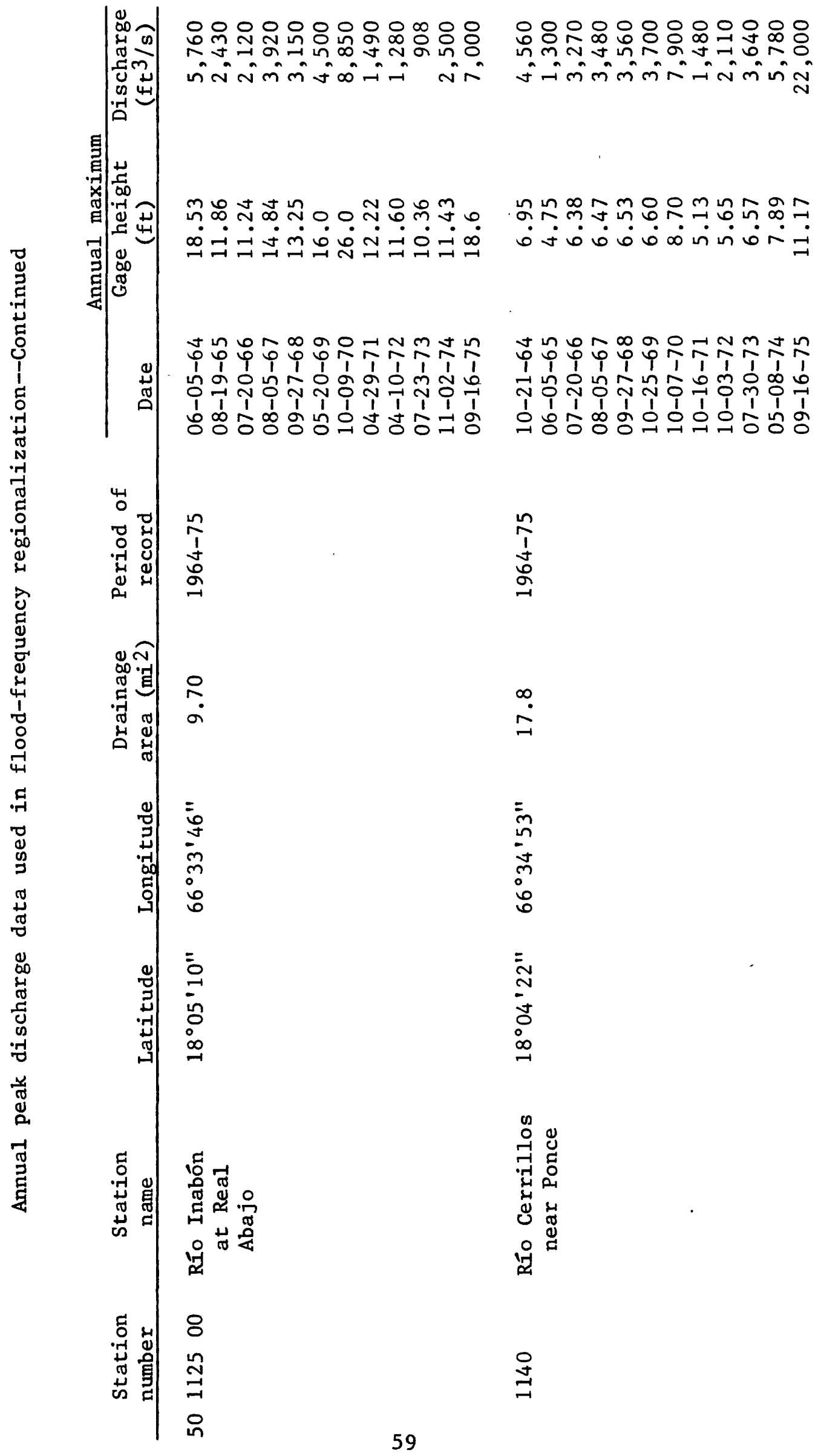




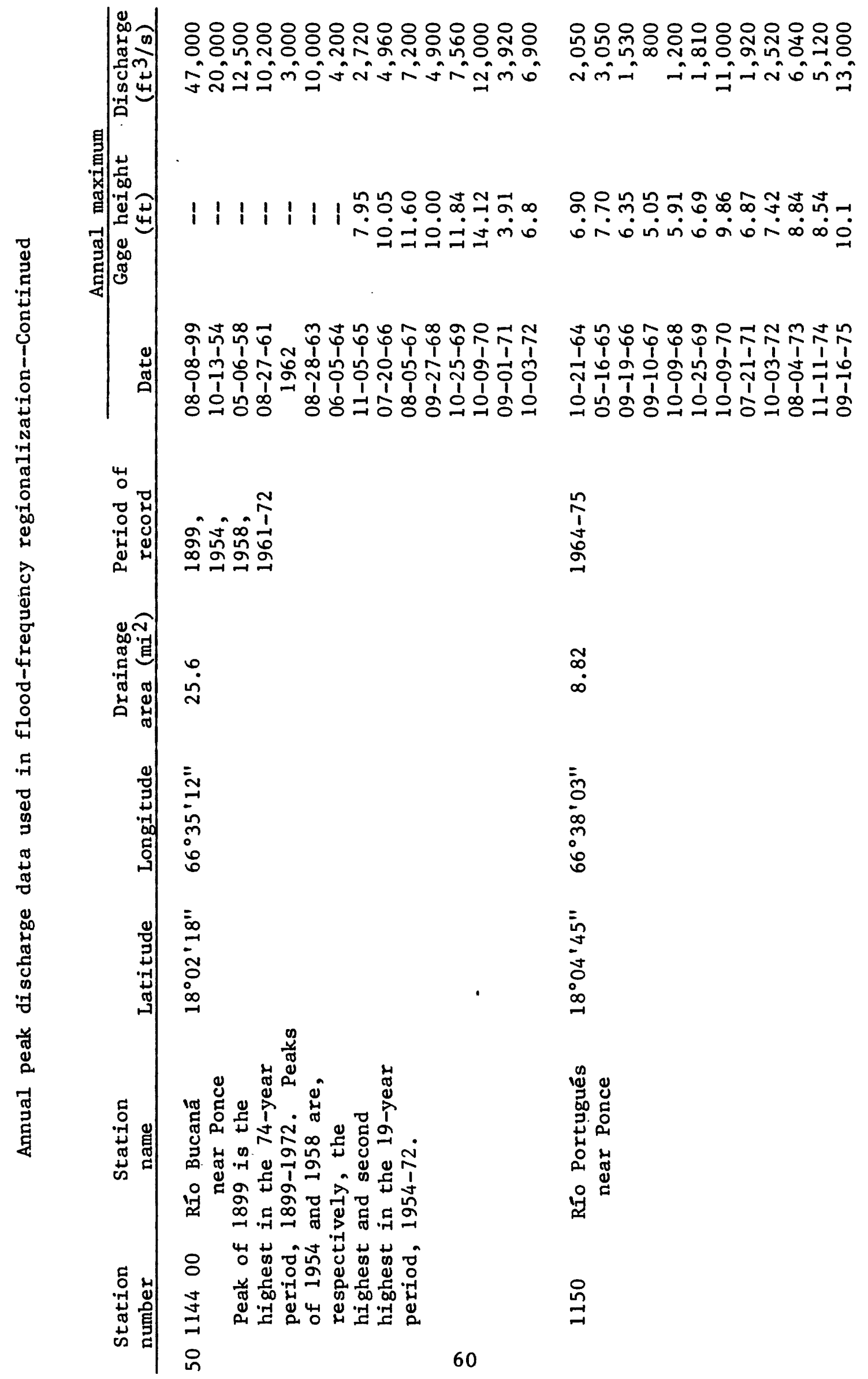




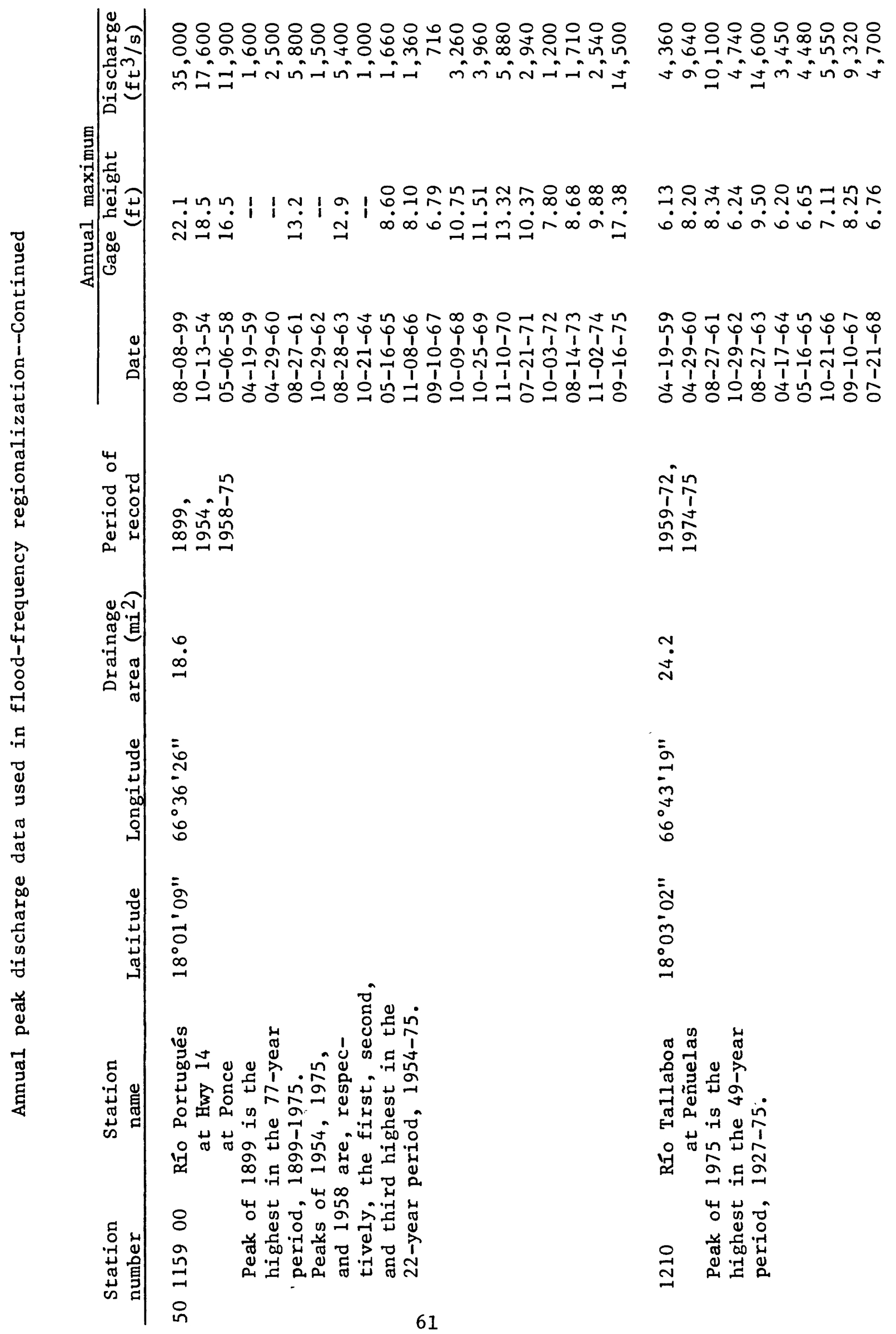




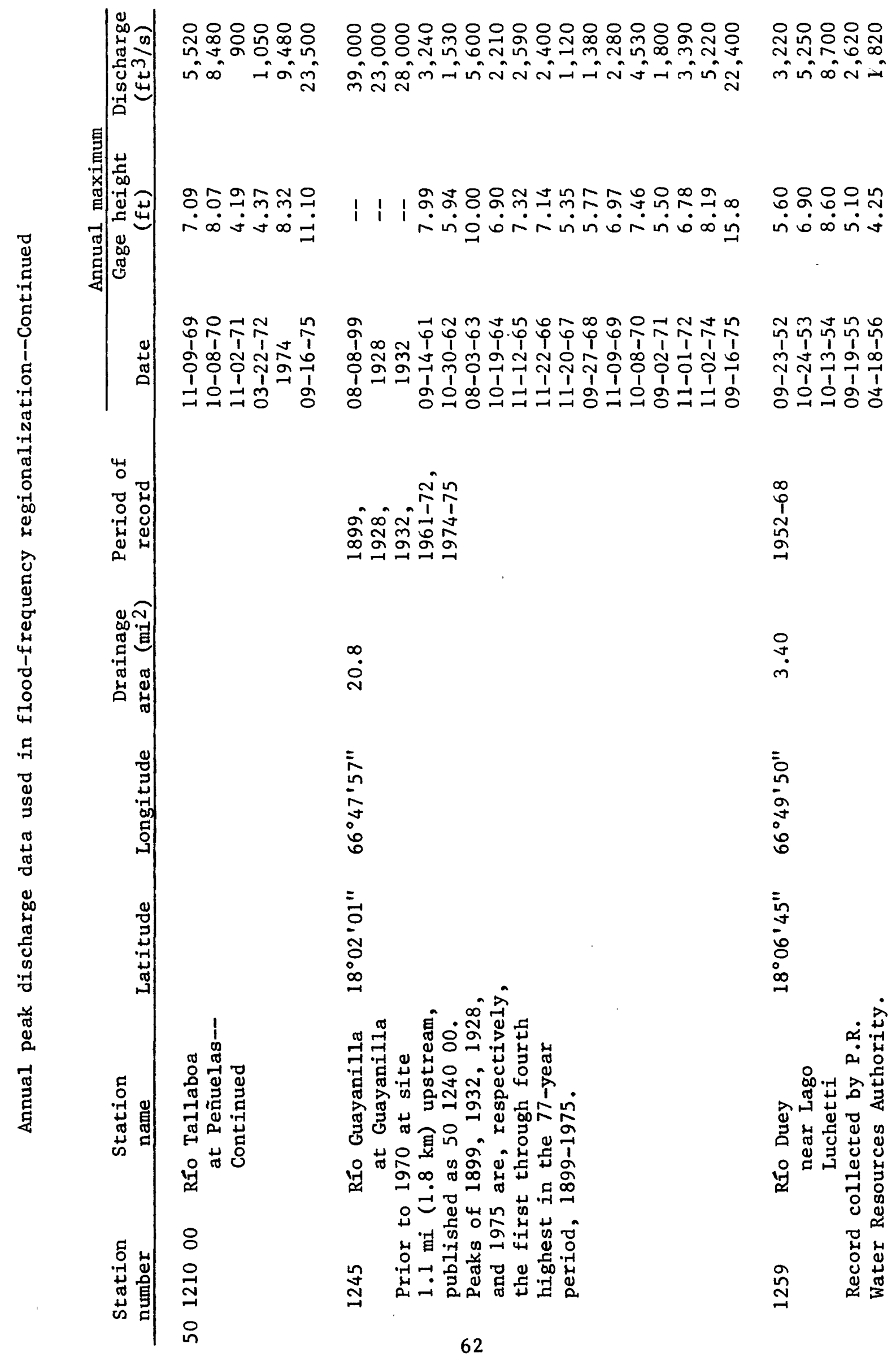




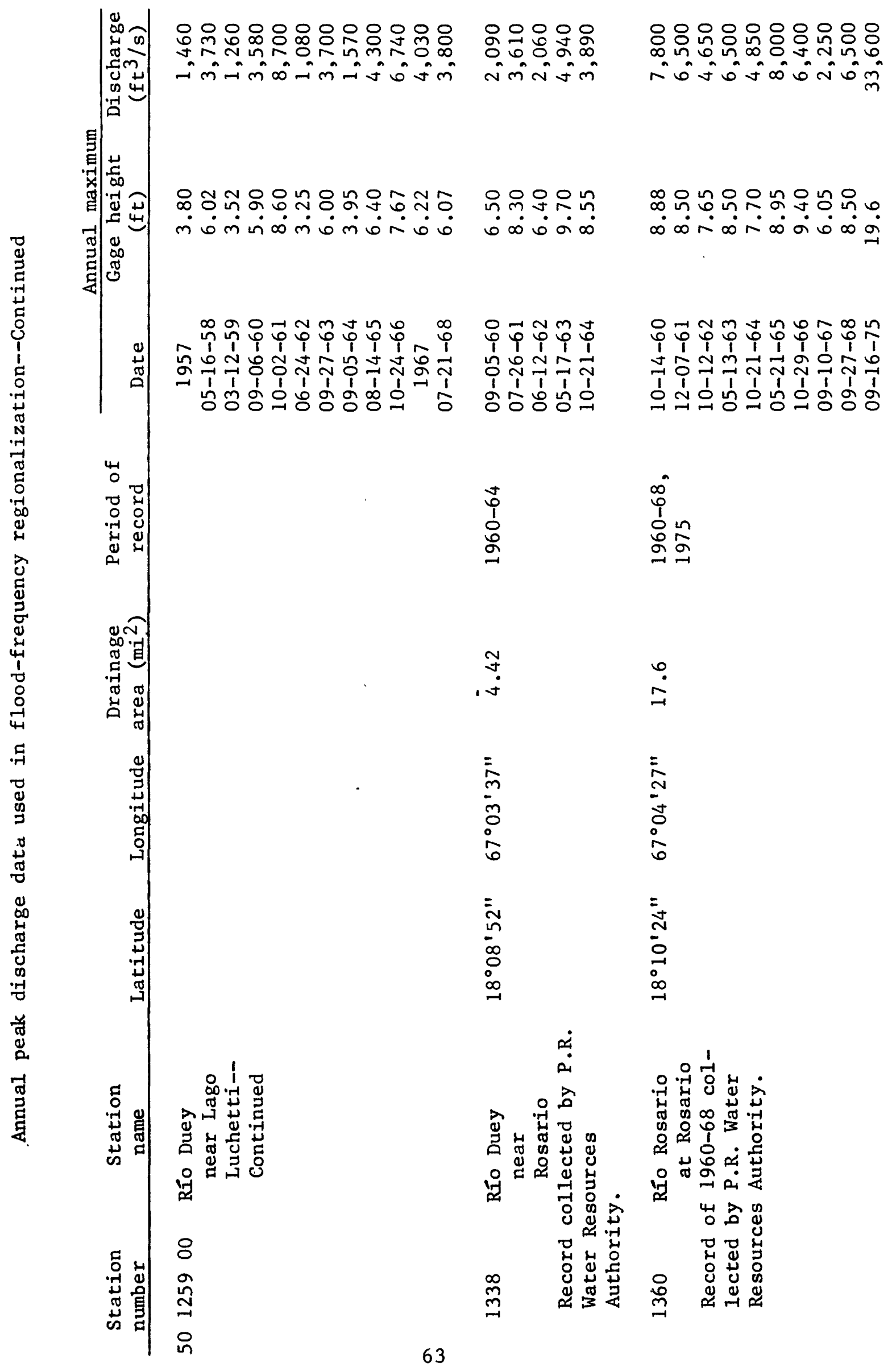




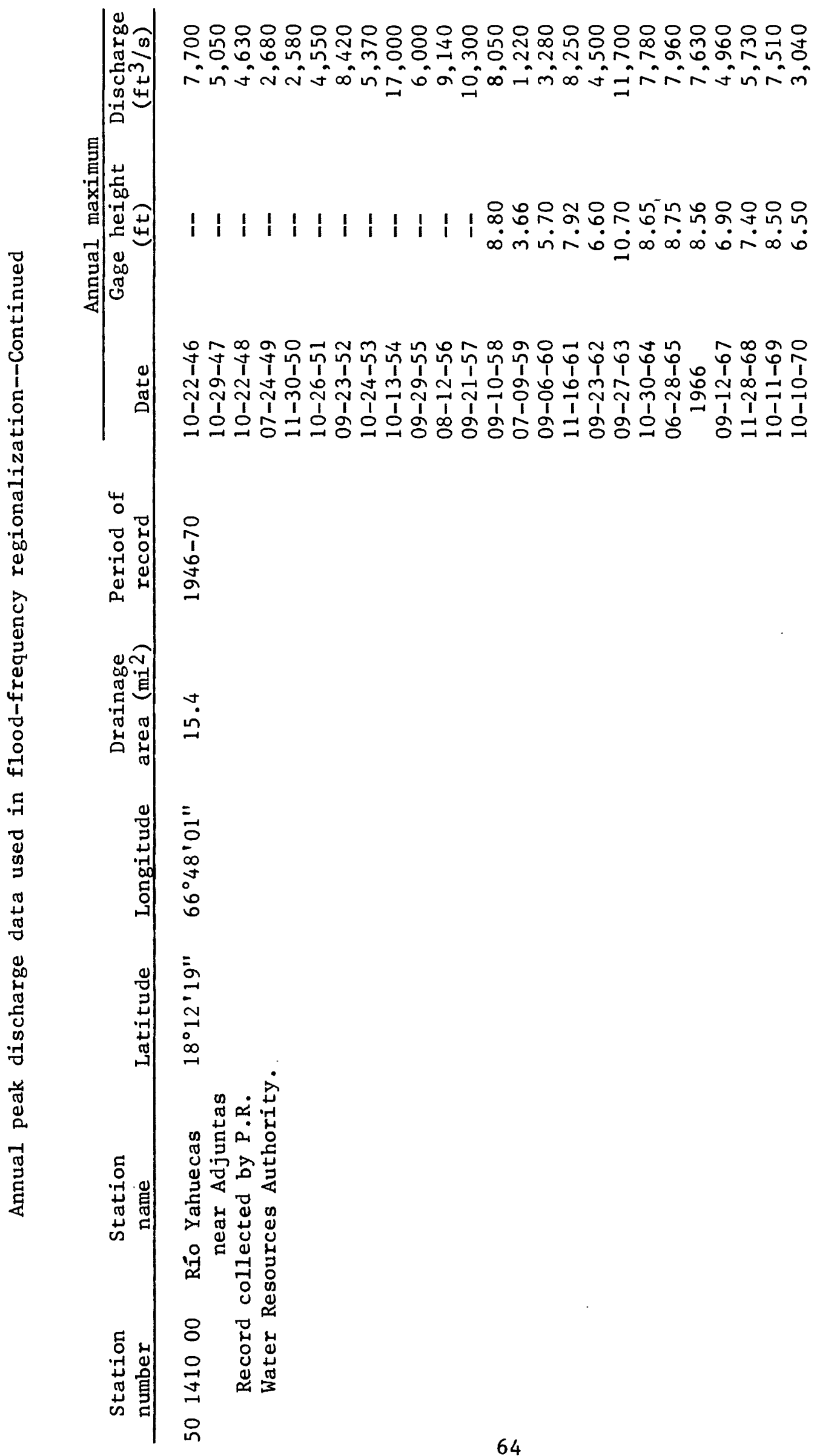




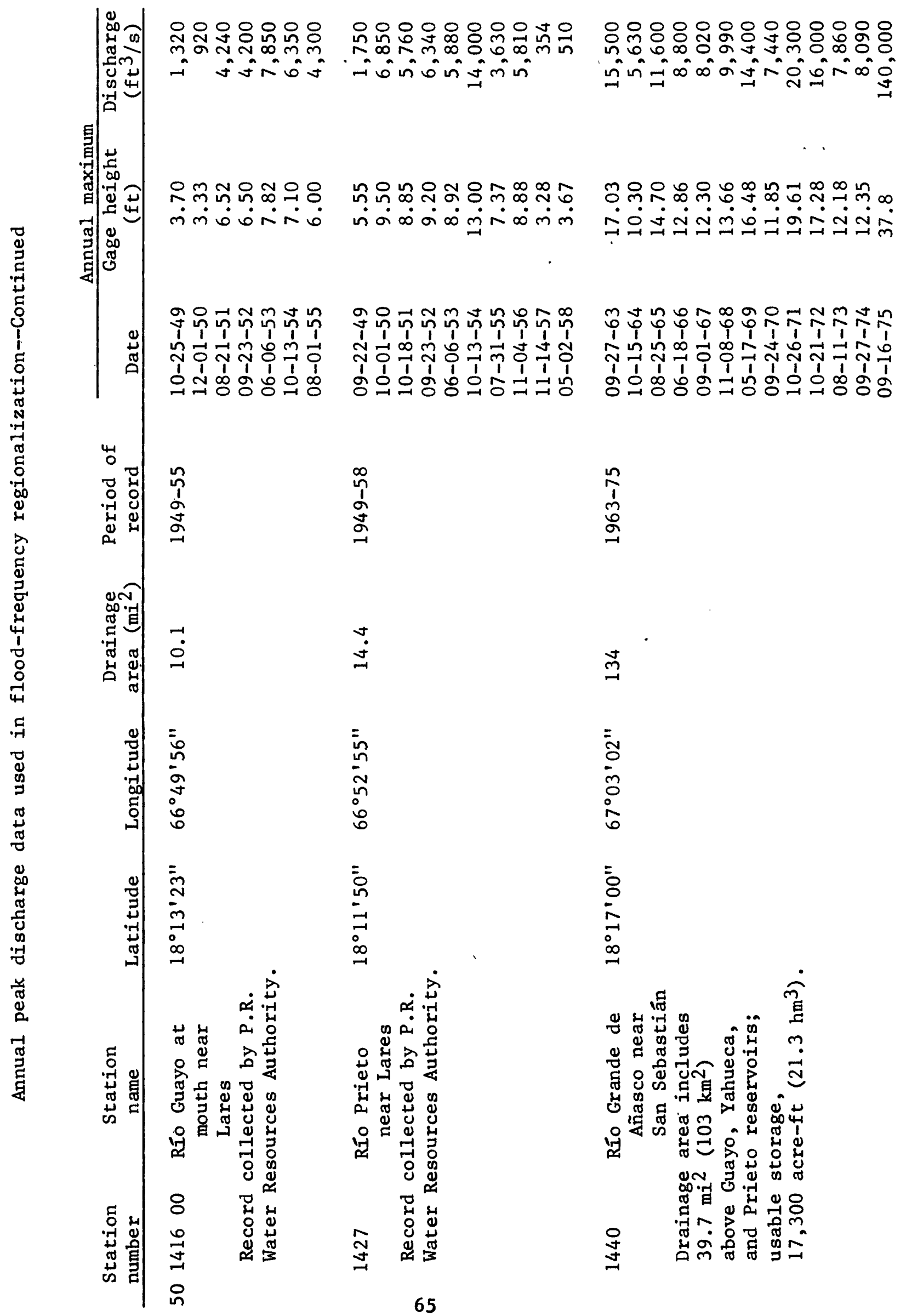




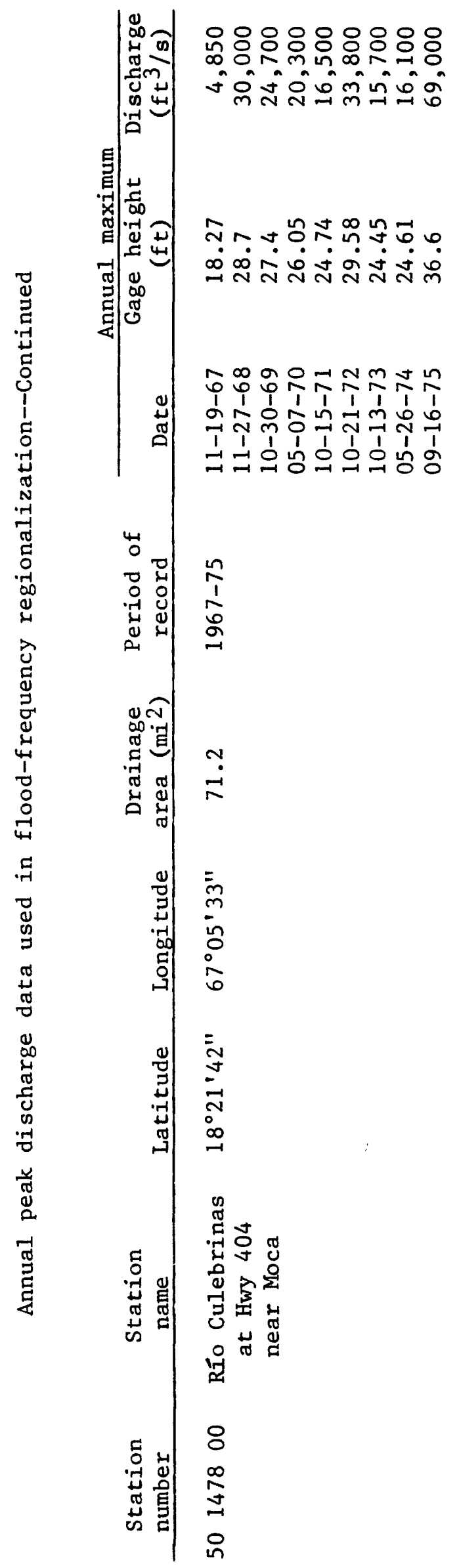

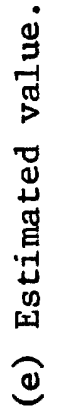



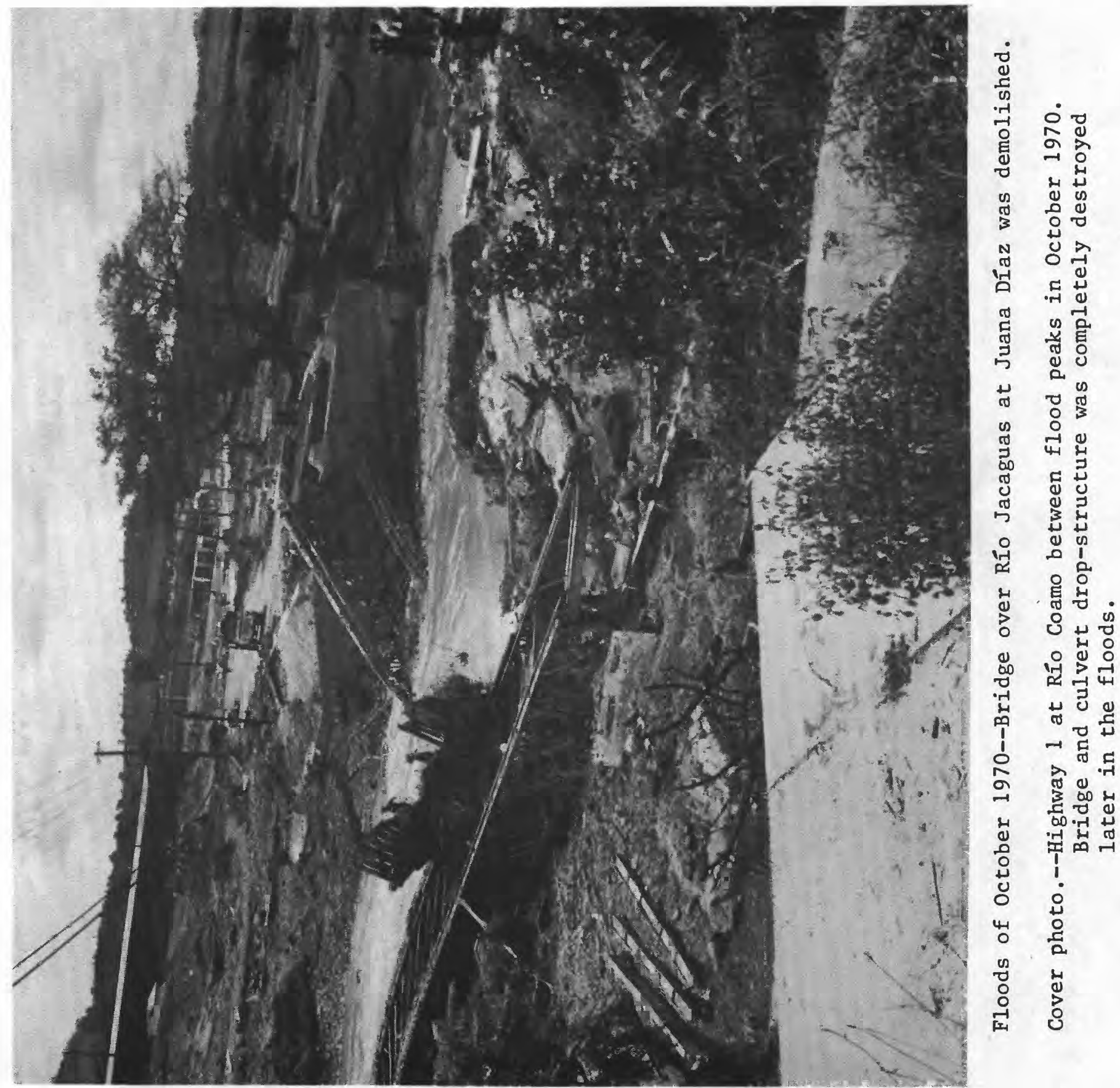


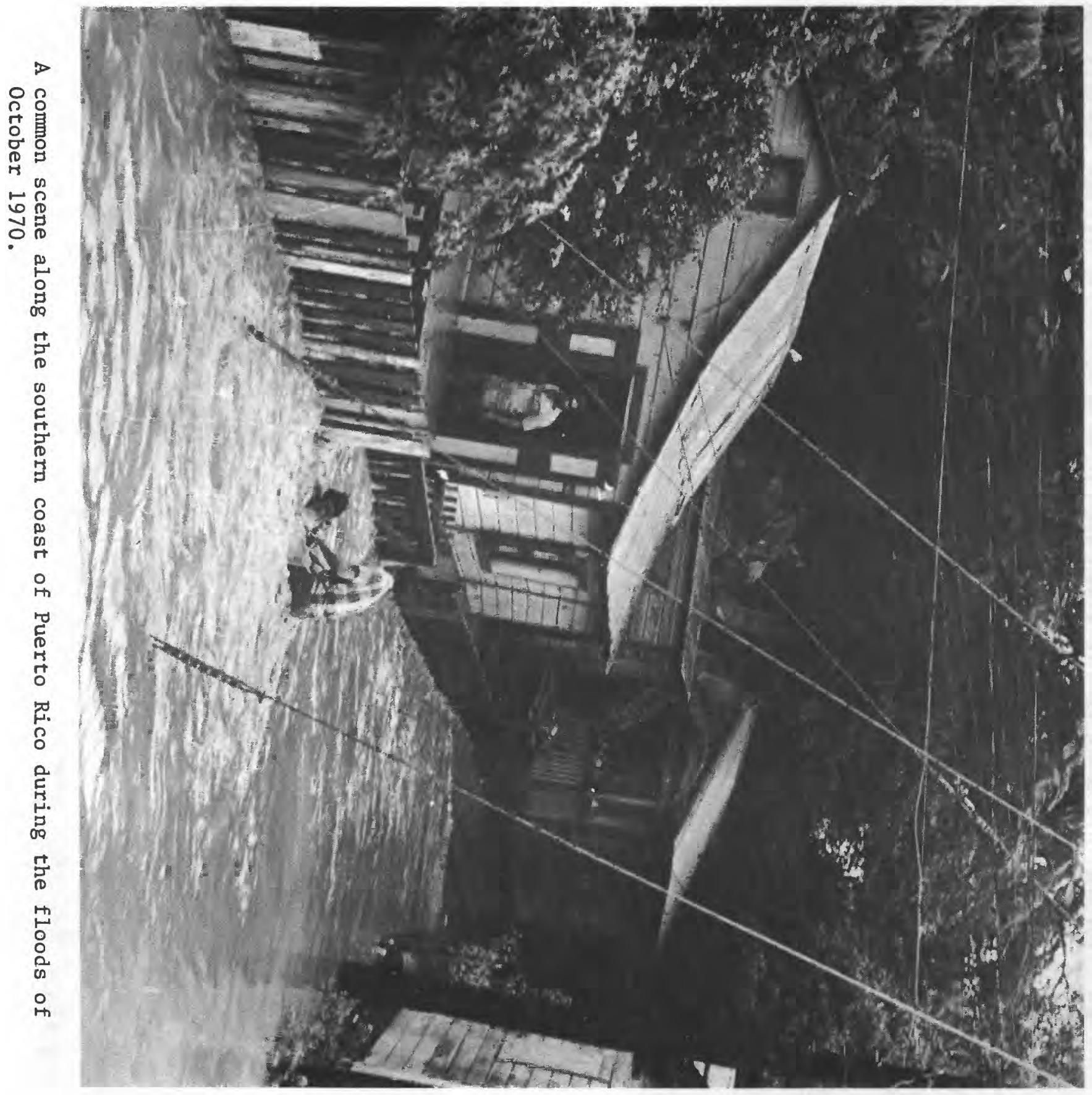


Factors for converting inch-pound units to International System (SI) units:

Multiply inch-pound units

by

\section{Length}

inches (in)

feet ( $f t)$

miles (mi)
square miles $\left(\mathrm{mi}^{2}\right)$
acre-feet (acre-ft)
cubic feet per second $\left(f t^{3 / s}\right)$

25.40

0.3048

1.609

Area

2.590

Volume

0.001233

Flow

0.02832 to obtain SI units

$$
\text { millimeters (mm) }
$$

meters (m)

kilometers ( $\mathrm{km})$

Square kilometers $\left(\mathrm{km}^{2}\right)$

cubic hectometer $\left(\mathrm{hm}^{3}\right)$

cubic meters per second $\left(\mathrm{m}^{3} / \mathrm{s}\right)$ 